\title{
RADIAÇÃO SOLAR, DESENVOLVIMENTO E PRODUÇÃO DE PALMITOS DE PUPUNHA (Bactris gasipaes H.B.K.) EM SISTEMAS AGROFLORESTAIS NA AMAZÔNIA OCIDENTAL
}

\author{
CÁSSIA REGINA DE ALMEIDA MORAES \\ Engenheiro Agrônomo
}

Orientador: Prof. Dr. MARCOS SILVEIRA BERNARDES

\begin{abstract}
Tese apresentada à Escola Superior de Agricultura "Luiz de Queiroz", Universidade de São Paulo, para obtenção do título de Doutor em Agronomia, Área de Concentração: Fitotecnia.
\end{abstract}

PIRACICABA

Estado de São Paulo - Brasil

Abril - 2002 


\section{Errata}

Cássia Regina de Almeida Moraes. Radiação solar, desenvolvimento e produção de palmitos de pupunha (Bactris gasipaes H.B.K.) em sistemas agroflorestais.

Substituir a Figura 30 da página 68 pela figura abaixo.

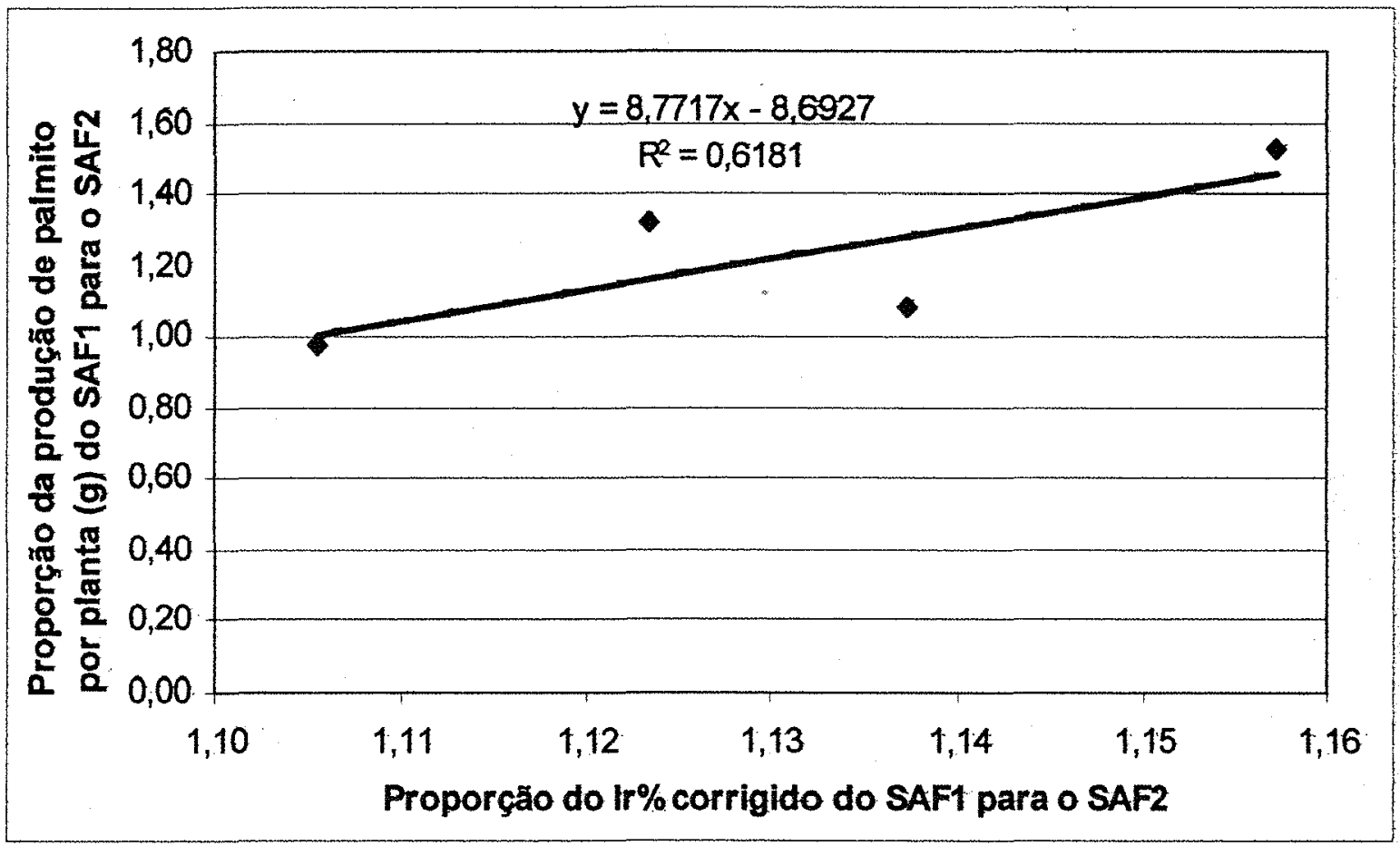

Figura 30 - Regressão linear entre a proporção do Ir\% corrigido do SAF 1 para - SAF 2 e a proporção da produção de palmito por planta (g) do SAF 1 para o SAF 2. 


\section{Dados Internacionais de Catalogação na Publicação (CIP) DIVISÃO DE BIBLIOTECA E DOCUMENTAÇĀO - ESALQ/USP}

Moraes, Cássia Regina de Almeida

Radiação solar, desenvolvimento e produção de palmitos de pupunha (Bactris gasipaes H.B.K.) em sistemas agroflorestais na Amazônia Ocidental / Cássia Regina de Almeida Moraes. - Piracicaba, 2002.

86 p. : il.

Tese (doutorado) - Escola Superior de Agricultura Luiz de Queiroz, 2002. Bibliografia.

1. Agrossilvicultura 2. Modelos matemáticos 3. Palmitos 4. Pupunha 5. Radiação solar I. Título

CDD 634.6 


\section{AGRADECIMENTOS}

Pois é... chegamos ao final desta jornada e é o momento de agradecer. Não é uma tarefa tão simples, pois foram tantas as pessoas que deixaram um pouco ou muito no trabalho. Mas vamos lá...

Ao Conselho Nacional de Desenvolvimento Científico e Tecnológico (CNPq) pela concessão da bolsa de estudos, em especial, à Izaura Yamada, Coordenadora do Acordo Brasil/Alemanha na área do Meio Ambiente - SHIFT, pelo profissionalismo e constante atenção e preocupação com o meu bem estar.

À chefia da Embrapa/CPAA, em especial ao Dr. Eduardo Morales, pela gentileza em fornecer-me as passagens a cada viagem para a realização das coletas dos dados e a coordenação do projeto SHIFT (Studies on Human Impact on Forest and Foodplains in the Tropics) para a execução da pesquisa na área do projeto.

Ao Dr. Luadir Gasparotto, pela confiança depositada em mim, pela disposição a ajudar-me frente a várias situações difíceis, pelo profissional dedicado e sério, por quem tenho profunda admiração e gratidão.

Aos operários rurais Firmino e Alailson que executavam suas tarefas com bom humor e presteza e com quem trabalhar era sempre um prazer.

Ao meu orientador prof ${ }^{\circ}$. Dr. Marcos Bernardes, que merece a abrangência do termo, pela paciência, ensinamentos e incentivo. Incentivo este, que vinha às vezes em forma de uma simples brincadeira ou em uma única palavra, mas sempre em momentos certos me massageando o coração. 
Aos colegas de pós graduação em SAFs, em especial a Leila Sobral, Ciro Righi e Aureny Lunz pela solidariedade fazendo-nos vivenciar o espírito de equipe no decorrer do curso.

Aos meus pais, Ubirajara e Therezinha Moraes, pela educação, pelo exemplo de honestidade e integridade, até hoje, retidos por mim e ao meu irmão César Augusto pela fidelidade à nossa irmandade.

Aos amigos de perto e também de longe, que foram amigos de todas as horas e mantiveram-se próximos do coração, demonstrando que a distância física nunca foi uma barreira, pois estavam presentes em vários momentos de alegria e de dor, sendo possível vivenciar o espírito da verdadeira amizade. São eles: Telma Passini, Vagner Benedito, Késia Oliveira, Helder Amorim, Salvador Torres, Alice Aranda, Hubert Weidner, Flávia e Eduardo Delgado. E em especial, a Marluce Cortez e Edivânia dos Santos. Que o tempo não apague as boas lembranças que tenho de todos.

A todos que contribuiram para que este trabalho chegasse ao final. Até mesmo aos que tentaram prejudicar-me de alguma forma, dificultando a realização deste, o meu obrigada, pois me fizeram superar meus limites. 


\section{SUMÁRIO}

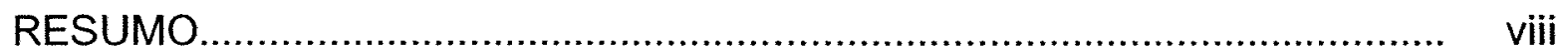

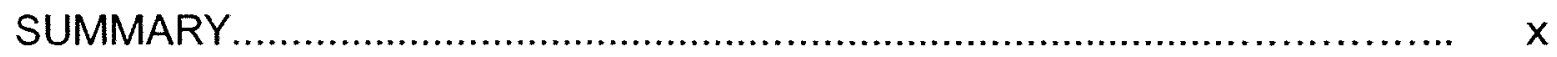

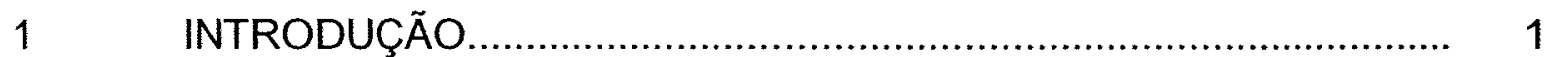

2 REVISÃO DE LITERATURA ................................................... 3

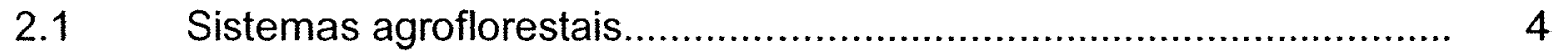

2.2 A Amazônia e os sistemas agroflorestais.......................................... 5

2.3 Cultivos agroflorestais praticados nos trópicos úmidos...................... 7

2.3.1 Cultivo itinerante ou migratório..................................................... 8

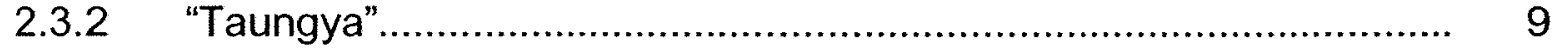

2.3.3 Cultivos em aléias ou "alley cropping"........................................... 9

2.3.4 Pomares caseiros....................................................................... 10

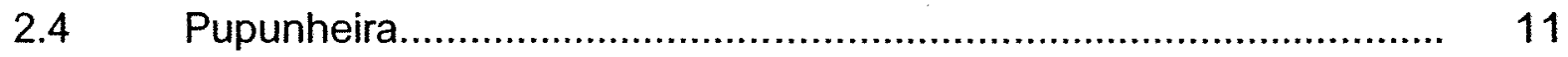

2.4.1 Pupunheira em SAF ................................................................... 13

2.4.2 Fisiologia da pupunheira............................................................ 14

2.5 SAF e Radiação solar.................................................................... 15

2.6 Modelagem de radiação solar em SAF............................................ 18

$3 \quad$ MATERIAL E MÉTODOS .......................................................... 20

3.1 Caracterização da área experimental............................................ 20

3.2 Delineamentoexperimental.......................................................... 24 
3.3 Condução do experimento .......................................................... 26

3.4 Determinação experimental da variáveis........................................ 29

3.4.1 Nas pupunheiras....................................................................... 29

3.4.1.1 Número de perfilhos .................................................................... 29

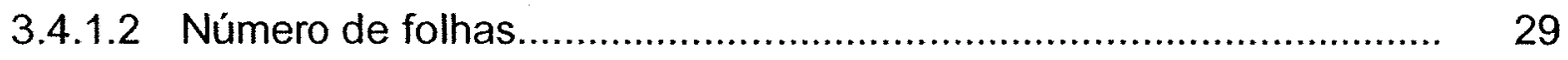

3.4.1.3 Massa da matéria seca (MS) das folhas e dos estipes.................... 29

3.4.1.4. Massa da matéria seca da parte aérea total das plantas colhidas.... 29

3.4.1.5 Índice da área foliar............................................................... 29

3.4.1.6 Altura das plantas................................................................ 30

3.4.1.7 Diâmetro da copa.................................................................. $\quad 30$

3.4.1.8 Número de palmitos colhidos ........................................................ 30

3.4.1.9 Massa, diâmetro e comprimento do palmito................................... 30

3.4.1.10 Massa dos residuos industriais do palmito...................................... 31

3.4.2 Nas árvores vizinhas........................................................... 31

3.4.2.1 Altura total e do tronco.............................................................. 31

3.4.2.2 Comprimento da copa.......................................................... 31

3.4.2.3 Diâmetro da copa................................................................... 31

3.4.3 Cálculo da disponibilidade de radiação para as pupunheiras........... 32

3.5 Análise estatística...................................................................... 34

$4 \quad$ RESULTADOS E DISCUSSÃO ............................................... 35

4.1 Crescimento e biometria das pupunheiras para produção de palmito.

4.1.1 Número de perfilhos por planta.................................................... 35

4.1.2 Número de folhas por planta................................................... 38

4.1.3 Massa da matéria seca (MS) das folhas e dos estipes................... 40

4.1.4 Massa da matéria seca (MS) da parte aérea total das plantas 42 colhidas.

4.1.5 Índice de área foliar (IAF) da planta....................................... 44

4.1.6 Diâmetro da copa................................................................... 47 


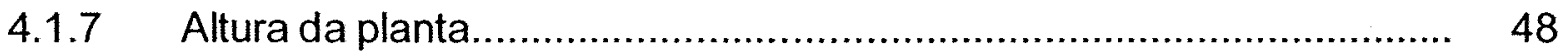

$4.2 \quad$ Produção das pupunheiras....................................................... 50

4.2.1 Número de palmitos colhidos por planta....................................... 50

4.2.2 Diâmetro e comprimento do palmito por planta................................ 51

4.2.3 Produção de palmito por creme por planta...................................... 53

4.2.4 Produção de resíduos industriais de palmitos por planta.................. 54

4.2.5 Produção total de palmito por planta.............................................. 56

4.2.6 Produção total de palmito por hectare ............................................. 58

4.2.7 Relações entre crescimento e a produção ...................................... 59

4.3 Crescimento e biometria das árvores vizinhas.............................. 60

4.3.1 Diâmetro da copa................................................................. 60

4.3.2 Altura das árvores................................................................ 62

4.3.3 Altura dos troncos.............................................................. 64

4.3.4 Comprimento das copas.......................................................... 64

4.4 Relações entre a produção e os fatores climáticos ........................ 66

$4.5 \quad$ Considerações finais.................................................................. 67

$5 \quad$ CONCLUSÕES................................................................ 72

REFERÊNCIAS BIBLIOGRÁFICAS ................................................. 73 


\section{RADIAÇÃO SOLAR, DESENVOLVIMENTO E PRODUÇÃO DE PALMITOS DE PUPUNHA (Bactris gasipaes H.B.K.) EM SISTEMAS AGROFLORESTAIS NA AMAZÔNIA OCIDENTAL}

Autora: Cássia Regina de Almeida Moraes Orientador: Prof. Dr. Marcos Silveira Bernardes

\section{RESUMO}

Sistemas agroflorestais (SAFs) podem apresentar vantagens em crescimento e produtividade em relação ao monocultivo., devido à seu efeito protetor do solo e do ambiente, especialmente na Amazônia onde a fertilidade é restritiva. A pupunheira (Bactris gasipaes H.B.K.) tem sido plantada na Amazônia sob inúmeros sistemas agroflorestais com sucesso. Entretanto, pouco se sabe a respeito das interaçōes biofísicas nesses sistemas. O objetivo do presente trabalho foi de identificar o efeito da radiação no desenvolvimento e produtividade da pupunheira e de adaptar um modelo matemático para estimar a disponibilidade de radiação para essa cultura em SAFs. Um experimento em blocos ao acaso foi conduzido em Manaus-AM, Brasil, de Março de 1999 até Agosto de 2000, Latossolo Amarelo textura muito argilosa. Pupunheiras para produção de palmito foram plantadas sob três tratamentos: i) em sistema agroflorestal com seringueiras (Hevea spp.), pupunheiras para produção de frutos e cupuaçuzeiro (Theobroma grandiflorum) (SAF1); ii) em sistema agroflorestal com pupunheiras para produção de frutos, cupuaçuzeiro, 
castanheiras do Brasil (Bertholletia excelsa) e urucum (Bixa orellana) (SAF2) e em monocultivo (testemunha). A pupunheiras foram cortadas para produção de palmito a cada 4 meses, aproximadamente. Em cada colheita, as plantas de palmito foram avaliadas em termos de: número de perfilhos e folhas, massa da matéria seca de folhas e total acima do solo, IAF, altura das plantas e diâmetro da copa. A produção de palmito foi avaliada em termos de número de palmitos por planta e seu diâmetro, comprimento e peso fresco. As árvores vizinhas às pupunheiras foram avaliadas em termos de altura de planta, comprimento e diâmetro de copa. A irradiância relativa atingindo a copa das pupunheiras $(\mathbf{H} \%=\mathbf{I} / \mathbf{l} \mathbf{0})$ foi estimada com um modelo matemático. Os resultados mostraram um maior crescimento e IAF das pupunheiras em monocultivo que nos SAFs, sem diferenças entre SAF1 e SAF2. A produção de palmito por planta foi similar entre os tratamentos. Pequenas diferenças nessas variáveis ocorreram em certas épocas de colheita, entre tratamentos. Devido ao maior número de pupunheiras por área, no monocultivo, a produtividade por área foi maior nesse tratamento. O número de folhas e de perfilhos foi maior nas colheitas de Dezembro de 1999 e Junho de 2000, provavelmente, devido à radiação solar mais intensa durante os períodos prévios a estas duas colheitas, apesar das limitações de água que ocorreram nessas ocasiões. IAF foi menor em Agosto de 1999 e maior em Dezembro de 1999. Por outro lado, a produção de palmito por planta foi menor em Agosto de 1999 e Dezembro de 1999, devido à redução na temperatura e na precipitação pluviométrica nos periodos prévios à essas duas colheitas. Houve uma relação inversa entre crescimento, especialmente da área fotossintetizante, expressa pelo número de folhas e de perfilhos e IAF, e a produção de palmito. Entretanto, maiores áreas foliares para captura de radiação, durante certo período, resultam em maior produtividade no período de rebrota subsequente como uma conseqüência da acumulação de reservas. Os resultados do modelo de irradiância demonstraram que a variação em crescimento e produção por pupunheira é devida a mudanças na disponibilidade de radiação para essa cultura. 


\title{
SOLAR RADIATION, DEVELOPMENT AND YIELD OF PALM HEART FROM PEJIBAYE (Bactris gasipaes H.B.K.) IN AGROFORESTRY SYSTEMS IN THE WEST AMAZON
}

\author{
Author: Cássia Regina de Almeida Moraes \\ Adviser: Prof. Dr. Marcos Silveira Bernardes
}

\section{SUMMARY}

Agroforestry systems (AFSs) can give growth and yield advantages compared to sole cropping, due to their soil and environmental protective role, specially in Amazon where soil fertility is a major constraint. Pejibaye (Bactris gasipaes H.B.K.) has been planted in Amazon under a number agroforestry systems with success. However, little is known about the biophysical interactions in these systems. The aim of the present study was to identify the effect of radiation on development and yield of pejibaye and to adapt a mathematical model to estimate the light availability for this crop under AFSs. A field experiment in randomized block design was conducted in Manaus-AM, Brazil, from March, 1999 to August, 2000, on a clayey Oxisol. Pejibaye for palm heart production was planted under three treatments: i) intercropped with rubber trees (Hevea spp.), pejibaye for fruit production and "cupuaçuzeiro" (Theobroma grandiflorum) (AFS1); ii) intercropped with pejibaye for fruit production, "cupuaçuzeiro", Brazil nut trees (Bertholletia excelsa) and annatto (Bixa orellana) (AFS2) and in sole crop (control). Pejibaye was harvested for palm 
heart every 4 months, approximately. In every harvest, pejibaye trees were evaluated in terms of: tiller and leaf number, leaf and total above ground dry matter, LAl, tree height, crown width. Palm heart yield was evaluated in terms of number of pieces per tree, its diameter, length and fresh weight. The neighbor trees to the pejibaye in the AFSs treatments were evaluated in terms of plant height and crown length and width. The relative irradiance reaching the pejibaye canopy $(1 \%=\mid r / l o)$ was estimated with a mathematical model. Results showed a larger growth and LAI of the pejibaye in sole crop over the AFS, without differences between AFS1 and AFS2. Palm heart yield per pejibaye tree was similar among treatments. Small differences in these variables occurred in certain evaluation periods between treatments. Due to larger number of pejibaye trees per area, the yield per ha was bigger in the sole crop treatment. Leaf and tiller number were larger in the harvest of December, 1999 and June, 2000, most probably, due to more intensive solar radiation during the previous period of these two harvests, despite water constraints occurring in the same occasions. LAl was smaller in August, 1999 and larger in December, 1999. Contrarily, palm heart yield per pejibaye tree was smaller in August, 1999 and December, 1999, due to the decline in temperature and rainfall in the previous period of these two harvests. There was a inverse relation between growth, specially of the photosynthetic area, expressed as leaf and tiller number and LAI, and yield. However, larger light capture leaf area during certain period result in higher yield in the next re-sprouting as a consequence of reserves accumulation. The results from the irradiance model demonstrated the variation in growth of pejibaye and its yield of palm heart per tree is due to changes in light availability to this crop. 


\section{INTRODUÇÃO}

A maior parte da região Amazônica não possui áreas fisiográficas e edafoclimáticas ideais para a prática agrícola convencional. Em geral, as principais associações de solos do trópico úmido amazônico estão distribuídas em duas seções fisiográficas: o platô amazônico e a planície de inundação. $O$ platô amazônico, compreende as terras firmes, pertencentes a diversas idades geológicas, abrangendo $87 \%$ da superfície desta região. Estes solos são predominantemente distróficos, de baixa fertilidade e com textura variando desde muito arenosa a muito argilosa. A planície de inundação compreende a área denominada de várzea, sujeita a inundações periódicas (Canto et al., 1992). Nesta, só se é possivel exercer a prática agrícola quando não se está na época das cheias dos rios, por formar uma área de razoável fertilidade, cultivando-se então, algumas espécies de ciclo anual.

Tais condições, associadas ao fato de que os monocultivos extensivos não estão ao alcance da unidade familiar típica da região, além de não serem modelos de produção adequados para áreas tropicais, leva-se a buscar novas alternativas. Para se preservar os recursos naturais da região Amazônica, passou-se a buscar uma forma racional de explorá-los, dentro dos princípios da sustentabilidade e da rentabilidade. Neste sentido, os Sistemas Agroflorestais (SAFs) são alternativas do uso da terra, pois constituem-se da associação de culturas perenes com culturas anuais ou animais ou ambos. Estes podem permitir melhor preservação dos recursos naturais com produtividade elevada e mantida ao longo do tempo. 
Por ser a pupunheira (Bactris gasipaes H.B.K.) uma cultura perene e típica da região vem despertando interesse dos agricultores e sendo estudada pelos pesquisadores desde a década de 70 (Yuyama, 1997). Devido ao esgotamento das reservas naturais palmiteiras da região sul do País, a pupunheira passa a ser uma alternativa importante para a produção de palmito, ocupando uma importante lacuna do mercado (Gomes \& Arckoll, 1988). Suas características de precocidade e perfilhamento garantem um rápido retorno financeiro. Assim, esta palmácea reúne características de grande interesse para compor os SAFs na região.

Este estudo visou identificar o efeito da radiação solar disponível para a pupunheira estabelecida em diferentes SAFs e no monocultivo, no seu crescimento, desenvolvimento e na produção de palmito. $A$ interceptação e a transmissão da radiação solar pelas plantas vizinhas à pupunheira foi estimada através de modelo matemático que também foi discutido e avaliado no presente estudo. Adicionalmente, o estudo teve por objetivo comparar a produção de palmito nos diferentes sistemas agroflorestais e no monocultivo de pupunheira. 


\section{REVISÃO DE LITERATURA}

$\mathrm{Na}$ época do Brasil Colônia, instalou-se no país uma sociedade agrícola de caráter predatório que considerava as florestas como barreira natural para a ocupação territorial e expansão das fronteiras. Desde então, os ciclos econômicos que construíram a nossa história, do pau-brasil à pecuária, foram todos baseados na destruição da cobertura vegetal original e na ausência de preocupação com o esgotamento destes recursos. As densas florestas tropicais eram tidas aos olhos dos colonizadores e, mais tarde, dos proprietários de terras, como inesgotáveis. Este processo fez-se sentir de maneira particularmente grave no caso das áreas de domínio da Mata Atlântica, principalmente no sudeste e no sul do País, resultando na redução de cerca de $90 \%$ da cobertura original dessa floresta. O mesmo poderá acontecer com a Amazônia, se medidas não forem tomadas.

Tem-se verificado que $80 \%$ das terras desmatadas na Amazônia Legal tornaram-se improdutivas sem o estabelecimento de uma atividade agrícola sustentável (Denich \& Kanashiro, 1998). Atualmente, os cenários nacional e internacional sinalizam mudanças importantes na forma do uso da terra. Além do enfoque de produtividade física e econômica, incorpora-se o enfoque ecológico, que passa a ter importância na matriz conceitual da exploração agrícola (Gasparotto et al., 1998). Após essa tomada de consciência, da necessidade de se preservar os recursos naturais da região Amazônica, passou-se a buscar uma forma racional de se explorar estes recursos dentro dos princípios do desenvolvimento sustentável e da rentabilidade. 
Desenvolvimento sustentável, por definição, è a "modificação da biosfera e a aplicação de recursos humanos, financeiros, bióticos e abióticos para satisfazer as reais necessidades humanas e melhorar a qualidade de vida do homem, considerando fatores ecológicos, econômicos e sociais, bem como as vantagens e desvantagens de ações alternativas, e garantindo a preservação dos recursos, para as gerações futuras" (World Conservation Strategy, 1980). Ou seja, o desenvolvimento sustentável implica em se conseguir o maior benefício dos recursos físicos, biológicos e culturais de uma localidade, dentro de uma estratégia para aumentar a auto-suficiência local e nacional. Este deve ainda estar ajustado à história e cultura da comunidade local, pois, uma vez que as necessidades básicas da população tenham sido atingidas, outras melhorias na qualidade de vida dependem de avaliações mais subjetivas (Golley, 1983).

Neste sentido, os sistemas agroflorestais (SAFs), têm sido recomendados como uma alternativa para o aproveitamento de áreas degradadas ou desmatadas, pois tem o potencial de gerar maior produtividade agrícola, florestal e pecuária, e pode reduzir os risco para o agricultor (Boas, 1991 e Montagnine et al., 1992). Os SAFs, desde que adaptados às condições do ambiente da região, poderão ser uma boa opção para minimizar os problemas agrícolas e de preservação do ambiente.

\subsection{Sistemas agroflorestais}

Os SAFs são sistemas do uso e manejo dos recursos naturais que integram consorciações de árvores com cultivos agrícolas e ou animais numa mesma área, simultânea ou escalonada no tempo e no espaço, de forma cientificamente estudada, ecologicamente desejável, praticamente factível e socialmente aceitável pelo produtor rural, de modo que este obtenha os benefícios das interações ecológicas e econômicas resultantes. São 
consorciações que se alicerçam nos princípios da sustentabilidade (Macedo \& Camargo, 1994 e Macedo et al., 1999).

Neste contexto, a adoção dos SAFs surge como um novo paradigma do desenvolvimento sustentável. Não como a melhor forma de uso da terra, mas como a mais adequada em muitas situações onde se busca aliar produção com conservação do ambiente.

\subsection{A Amazônia e os sistemas agroflorestais}

Na Amazônia, os SAFs têm origem em longa tradição indigena, modificando-se com a colonização e a evolução dos costumes. Caracterizam-se por utilizar uma grande diversidade de plantas, manejadas para atender as necessidades vitais das comunidades, isto é, alimentação, saúde (uso de plantas medicinais), confecção de vestuário, construção de casas e abrigos e manufatura de diversos objetos de uso comum. Incluem também: sistemas indígenas de cultivo, cultivo itinerante ou migratório, sistemas tradicionais abertos ao mercado e intercultivo de plantas perenes arbóreas, arbustivas e palmáceas (EMBRAPA, 1991).

De uma maneira geral, o modelo tradicional largamente utilizado na Amazônia, embora de ecologicamente desejável e adaptado aos mercados locais, não atende totalmente as necessidades atuais, pois a qualidade dos produtos não corresponde às exigências dos mercados urbanos. Também não permite uma melhoria sensivel do nivel de vida do produtor, pois sua produtividade ainda é baixa.

Para aumentar a competitividade dos SAFs frente a outras alternativas convencionais de agricultura, torna-se necessário conduzí-los do seu atual estado de economia de subsistência de fronteira agrícola para o de economia de mercado. Isso implica, dentre outras coisas, em promover o aumento da sua produtividade, através do desenvolvimento e disseminação de tecnologias adequadas (Canto et al., 1992). A implementação de sistemas agrosilviculturais 
na região, possibilitaria também, uma importante contribuição para a conservação dos recursos genéticos vegetais da Amazônia (Canto et al., 1992).

Os SAFs apresentam-se como uma alternativa de grande importância para tornar os sistemas de produção florestal, agrícola e animal sustentáveis, devido às funções biológicas e ecológicas e sócio-econômicas que podem cumprir. O princípio biológico e ecológico, caracterizado pela "biodinâmica da sobrevivência", que otimiza ao máximo o aproveitamento da energia solar através da multiestratificação diferenciada de uma grande diversidade de espécies. Estas exploram os perfis vertical e horizontal da paisagem, visando a utilização e recirculação dos potenciais produtivos dos ecossistemas (Macedo,1992).

Segundo Macedo et al. (1999), as espécies arbóreas, por possuírem raízes longas exploram maior volume de solo, são capazes de absorver nutrientes e água em locais onde os cultivos agrícolas não conseguiram, uma vez que, nestes, geralmente as raízes absorventes estão concentradas na camada superior do solo, de 0 a $20 \mathrm{~cm}$ de profundidade. Também para estes autores, o dossel das copas formado pela diversidade de espécies vegetais proporciona cobertura do solo através da deposição de camada densa de material orgânico gerada continuamente pela queda das folhas e ramos das diferentes culturas. Isso aumenta a proteção do solo contra a erosão, diminui o escorrimento superficial da água de chuva, promove maior tempo de permanência da água no solo, reduz a temperatura do solo, aumenta a quantidade de matéria orgânica incorporada e, conseqüentemente, melhora as suas propriedades químicas, físicas e biológicas.

A ciclagem de nutrientes é um outro aspecto que deve ser enfatizado, principalmente daqueles facilmente lixiviados, como o cálcio, potássio e enxofre. Plantas arbóreas com suas raízes longas retiram esses nutrientes das camadas mais profundas do solo e os devolve à superfície pela queda das folhas e ramos, tornando-os disponíveis novamente às plantas, após sua mineralização (Macedo et al., 1999). Bernardes \& Lima (2000), estudando SAF 
com seringueira (Hevea brasiliensis) no sul da Bahia, encontraram teores de matéria orgânica no solo similares aos encontrados na mata original. Para os autores, a recuperação do solo deveu-se principalmente a proteção contra a erosão, a menor oxidação da matéria orgânica resultante de uma menor temperatura do solo e a produção de fitomassa pela cobertura vegetal.

Atenção também deve ser dada a utilização de espécies florestais que interagem simbioticamente com bactérias do gênero Rhizobium ou Bradyrhizobium favorecendo a absorção de nitrogênio pelas plantas, pois são fixadoras deste elemento. Estas em sua maioria são leguminosas tropicais e subtropicais (Brewbaker, 1987).

O princípio social em que se fundamentam os SAFs, é de manter o homem no campo, proporcionando melhoria nas condições de vida devido à diversidade de produção e da contínua necessidade de mão-de-obra uma vez que as culturas exigem tratos culturais e são colhidas em diferentes épocas (Engel, 1999 e Macedo et al., 1999).

O princípio econômico dos SAFs é exatamente em buscar a sustentabilidade econômica, produzindo diferentes produtos ao longo do ano, sendo capaz de colocar no mercado produtos de acordo com a demanda. Torna-se de extrema importância a escolha das espécies que serão implantadas nos sistemas para que se obtenham produtos de maior aceitação e venda no mercado em determinadas épocas do ano. Além da comercialização escalonada dos produtos obtidos, há também maiores oportunidades de emprego no meio rural, vide que para o manejo do sistema, é necessária mãode-obra variada (Engel, 1999 e Macedo et al., 1999).

\subsection{Cultivos agroflorestais praticados nos trópicos úmidos}

Torquebiau (2000) em revisão recente sobre classificação dos SAFs propôs algumas categorias básicas por desenho dos sistemas, que são:

- cultivos agrícolas sombreados pelas árvores, 
- sistemas agrosilviculturais contendo cultivos agrícolas, árvores e arbustos,

- cultivos agrícolas e árvores em um arranjamento linear,

- agrosilvipastoris.

O autor comenta que esta classificação pode ser subdividida em seqüencial e simultânea. A clara diferença entre estes dois grupos, é que no primeiro, os componentes se sucedem no tempo, enquanto que no simultâneo, os componentes do sistema possuem uma interação direta, uma vez que encontram-se ao mesmo tempo na área de cultivo.

\subsubsection{Cultivo itinerante ou migratório}

A agricultura migratória sempre foi praticada como uma forma tradicional de uso da terra na Amazônia, consistindo na derrubada da floresta, aproveitamento da madeira e lenha e queima da mata em pequenas áreas onde são feitos cultivos de plantas de ciclo anual de subsistência por um período de dois a três anos. Em seguida, esta área é abandonada, podendo antes passar por um período de pastoreio, e depois deixada em pousio para regenerar até o estágio de capoeira, onde o ciclo recomeça. Este cultivo é classificado como sistema agroflorestal seqüencial (Torquebiau, 2000).

Este sistema varia de acordo com as condições ecológicas locais. Em algumas áreas, a derrubada da floresta acontece no período seco, a queima antes das primeiras chuvas e o plantio de espécies como o milho, feijão, mandioca e banana é realizado aproveitando as cinzas da queimada e o material em decomposição.

Em regiões com baixa pressão de ocupação da terra; onde a área pode ser deixada em pousio por tempo suficientemente longo, e em que os colonos tenham esta tradição, o sistema tem funcionado relativamente bem durante séculos (Engel, 1999). A África e a América Latina são as duas regiões dos trópicos onde se utiliza esse sistema de cultivo (Bandy et al., 1994). 


\subsection{2 "Taungya"}

Este termo tem origem na Birmânia, significando "cultivos de encosta", e foi originalmente usado para designar o plantio de árvores em áreas de agricultura migratória. Atualmente este termo é usado para designar qualquer combinação de cultivos durante as primeiras fases de estabelecimento das árvores, onde o objetivo principal é a produção de madeira (Engel, 1999). O sistema "taungya" também é outro exemplo de cultivo seqüencial (Torquebiau, 2000). Implica no cultivo de espécies alimentícias anuais conjuntamente com espécies florestais durante os primeiros anos de estabelecimento. Aconselhase, no caso de cultivos cuja colheita sejam as raízes, que estas devam ser plantadas a mais de $1 \mathrm{~m}$ das árvores durante o seu estabelecimento e a $2 \mathrm{~m}$ durante os anos posteriores. As árvores devem ser manejadas para favorecer a cultura agricola, com uso de podas, desbastes, etc. O sombreamento excessivo pelas árvores após alguns anos determina o final do sistema agroflorestal e início da plantação florestal pura, cuja duração dependerá da espécie e densidade do plantio (Beer et al., 1994 e Engel, 1999).

Muitos plantios de espécies lenhosas, tanto em grandes como em pequenas propriedades do sul da Bahia e de vários outros estados amazônicos, tiveram início através de um sistema semelhante ao "taungya". Entretanto, a modalidade de exploração das culturas alimentares não foi o da parceria e sim na base de contratação de mão-de-obra pelo proprietário. Desta forma, o sistema não seguiu um dos objetivos do processo que é o de promover melhorias sociais para os parceiros (Ruthemberg, 1980 e Gomes, 1992).

\subsubsection{Cultivo em aléias ou "alley cropping"}

Os cultivos em aléias foram desenvolvidos na Nigéria e constituem-se em práticas viáveis e com aplicação potencial para todas as regiões tropicais, especialmente em áreas com problemas de fertilidade ou terrenos declivosos. São formados por árvores e arbustos geralmente fixadores de nitrogênio, como as espécies do gênero Acácia, Sesbania, Leucaena, Gliricidia, Calliandra, 
Prosopis, intercaladas em faixas com culturas anuais, tais como milho, feijoeiro, soja, mandioca e cereais (Broonkird et al.,1984 e Engel,1999).

Uma característica estrutural desse tipo de arranjo linear é que as árvores e as culturas agrícolas aparecem lado a lado, podendo estas serem tolerantes ou não à sombra. São sistemas classificados como simultâneos e ao mesmo tempo em arranjo linear (Torquebiau, 2000).

Primeiramente, as árvores são plantadas em fileiras únicas ou duplas. A sombra produzida pela copa densa das árvores reduz a infestação com plantas daninhas e diminui o custo de manutenção. As culturas anuais são plantadas na próxima estação chuvosa, após a poda da parte aérea das árvores, seguida da incorporação dos resíduos ao solo para a melhoria da fertilidade. Estes resíduos, também podem ser empregados na alimentação animal como forragem de alta qualidade.

\subsubsection{Pomares caseiros}

Como a agricultura migratória, os pomares familiares constituem uma prática agroflorestal muito antiga, utilizados para prover necessidades básicas de famílias ou comunidades pequenas, com venda ocasional de excedentes de produção. Constitui-se em complexo de plantas perenes ou semiperenes, utilizado por pequenos agricultores com uma superfície da ordem de um hectare e que encontra-se próximas às suas casas (Ruthemberg, 1980).

Este sistema é classificado por sistema simultâneo (Torquebiau, 2000) e possui características vantajosas, como a necessidade de poucos insumos e capacidade constante de produção; necessidade de mão-de-obra escalonada ao longo do ano todo e concentrada na familia. São os sistemas de produção mais parecidos com os ecossistemas naturais e com alta produtividade por unidade de área. Caracterizam-se por sua complexidade, com muitos estratos e grande variedade de árvores, cultivos e animais domésticos, com produção ao longo de todo $o$ ano de frutos, legumes, fibras, madeira, plantas medicinais e aromáticas, galinhas, porcos, etc. (Engel, 1999). 


\subsection{Pupunheira}

Para todos os SAFs dos trópicos úmidos recomendam-se a utilização de fruteiras regionais e culturas perenes. Sendo a pupunheira (Bactris gasipaes H.B.K.) uma palmeira nativa e perene da região Amazônica, sua utilização parece ser viável para compor os SAFs nesta região.

A pupunheira é uma espécie que vem sendo cultivada há anos por várias tribos indígenas das Américas do Sul e Central (Almeyda \& Martin, 1980). Considera-se que os tipos de pupunheiras cultivadas atualmente são o resultado da domesticação de diferentes populações silvestres por tribos indígenas nas suas rotas migratórias (Clement, 1987 e Villachica, 1996a).

Sua distribuição geográfica compreende os territórios entre latitudes $16^{\circ} \mathrm{N}$ e $17^{\circ} \mathrm{S}$, sendo encontrada no norte de Honduras até o sul da Bolivia e do leste de São Luis (MA) ao Equador. É natural de áreas com precipitações pluviais entre 1500 e $6000 \mathrm{~mm} / \mathrm{ano}$. Porém, melhores resultados foram observados onde a precipitação está entre 2000 e 3000 mm/ano (Mora Urpi,1984 e Barbosa, 1993).

Por ser uma planta rústica, adapta-se a um grande número de condições ecológicas, embora as temperaturas médias minimas para o seu desenvolvimento estejam entre $18-24^{\circ} \mathrm{C}$ e as médias máximas de $33^{\circ} \mathrm{C}$ (Rothschuh, 1983). Produz em solos ácidos e de baixa fertilidade, como são os solos da Amazônia, mas apresenta maior produção, quando adubada apropriadamente (Bovi, 1998).

É uma palmácea da família das Arecaceas, multicaule, monóica, alógama, com alto grau de incompatibilidade. Possui porte ereto e, em fase adulta pode alcançar $20 \mathrm{~m}$ de altura e diâmetro do estipe 10 a $30 \mathrm{~cm}$, sendo este monopodial e cilíndrico. O estipe está dividido em cicatrizes onde se inserem as folhas, podendo ou não ser recoberto por espinhos. Suas folhas são pinadas, e também podem conter ou não espinhos no pecíolo e ráquis (Mora Urpi, 1984 e Clement, 1995). 
As flores pistiladas e estaminadas são de cor branco-amarelada e se encontram na mesma inflorescência. As plantas produzem de seis a oito inflorescências por ano. Os frutos são drupas que quando jovens são verdes e ao amadurecerem tornam-se amarelos, vermelhos e algumas combinações dessas cores. Seu fruto é de alto valor nutricional, rico em proteínas, lipídeos, vitamina $A$ e ácido ascórbico. A planta leva em média trêsanos para a produção de frutos (Camacho, 1976 e Mora Urpi, 1984).

A pupunheira produz brotos basais que crescem rapidamente formando os perfilhos. Estes, quando atingem aproximadamente $7 \mathrm{~cm}$ de diâmetro, podem ser cortados para a extração do palmito, que nada mais é do que um conjunto de folhas imaturas, envoltas pelas bainhas das folhas mais velhas. $O$ palmito apresenta uma composição semelhante ao do aspargo branco, excetó pelo conteúdo de carboidratos, ao redor de $3 \%$ no palmito e $6,7 \%$ no aspargo. Possui $90 \%$ de água, 2,94 a $4,74 \%$ de proteínas e 0,57 a $1,01 \%$ de fibra e outros (Villachica, 1996a).

A intensa exploração comercial da juçara (Euterpe edulis) e do açaí (Euterpe oleracea) para extração do palmito contribuiu drasticamente para a diminuição das suas reservas naturais, o que comprometeu sensivelmente a exportação do palmito em conserva oriundo desta palmeira, que hoje representa pouco mais de $10 \%$ da exportação brasileira. O Brasil exporta palmito em conserva para mais de 25 países. Os principais países importadores em 1998 foram Argentina, Estados Unidos, França, Uruguai, Espanha e Itália (FNP CONSULTORIA \& COMÉRCIO, 1999). Sendo assim, o palmito de pupunha surge como uma boa alternativa, pois a juçara não emite brotações laterais, ou seja, não perfilha e leva de 8 a 12 anos para ser executado um único corte. Já o açaí, perfilha, porém tem um ciclo de produção entre o plantio e o primeiro corte de aproximadamente 4 a 6 anos, enquanto na pupunheira, a partir dos 18 meses de idade, pode-se iniciar o corte dos seus perfilhos, aptos para a extração do palmito. 
Além das vantagens da sua precocidade e do seu farto perfilhamento, que promove um retorno financeiro imediato, o palmito de pupunha não apresenta escurecimento enzimático, pois não possui em sua composição química as enzimas polifenol oxidase e peroxidase, um dos principais problemas no processamento do palmito de outras espécies de palmeira (Ferreira, 1982 e Bovi, 1995).

\subsubsection{Pupunheira em SAF}

A pupunheira vem sendo amplamente cultivada em SAFs na Amazônia. No Projeto RECA (Reflorestamento Econômico Consorciado e Adensado), uma associação de pequenos produtores rurais, assentados pelo Instituto Nacional de Colonização e Reforma Agrária - INCRA, no Estado do Acre, existem atualmente, cerca de 650 ha de SAFs formados por pupunheira, cupuaçuzeiro (Theobroma grandiflorum) e castanheira-do-brasil (Bertholletia excelsa), estabelecidos em diversos arranjos. Os plantios foram implantados a partir do ano de 1989, em áreas recém derrubadas de florestas primária ou secundária, encontrando-se atualmente com idades variando de $9-12$ anos. São SAFs do tipo silviagrícola, conhecidos na Região Amazônica como consórcio agroflorestal comercial ou multiestratificado. Nesses modelos há a formação de três estratos horizontais. O cupuaçuzeiro forma o primeiro estrato, com altura média de $4 \mathrm{~m}$; o segundo é composto pela castanheira-do-brasil, com aproximadamente $11 \mathrm{~m}$ e o terceiro é formado pela pupunheira, atingindo $15 \mathrm{~m}$. O espaçamento adotado no sistema, pela maioria dos produtores, foi de 7 $\mathrm{m}$ entre linhas por $4 \mathrm{~m}$ entre plantas, com pequenas variações. No entanto, a densidade de cada espécie e o arranjo são bastante diferentes, variando de 120 a 258 cupuaçuzeiros/ha, 60 a 198 pupunheiras/ha e 40 a 60 castanheiras/ha (Lunz et al., 2000).

Silva \& Dias (1987), estudando a pupunheira em diferentes espaçamentos em consórcio com o cacaueiro (Theobroma cacoa) no estado do Amazonas, constataram nos resultados parciais que não houve indícios de 
incompatibilidade interespecífica entre estas culturas e que um fator condicionante para o sucesso deste agrossistema, é a adequação do arranjo espacial desta palmácea. Silva \& Yuyama (1997), avaliando o cultivo da pupunheira com espécies de ciclo curto como amendoinzeiro, arroz, sorgo e mandioca, constataram que a mandioca foi a lavoura mais produtiva. $A$ pupunheira associada com gramíneas apresentou amarelecimento das folhas $e$ menor crescimento.

\subsubsection{Fisiologia da pupunheira}

A luz é um fator intrinsecamente complexo, que afeta praticamente todos os fenômenos biológicos. Em uma área onde existem plantas de diferentes alturas em diferentes espaçamentos, a qualidade e a quantidade de luz variam espacial e temporalmente. Em cada espaço delimitado de solo, certas características da luz são previsíveis. Nas plantas de menor altura, com dossel baixo e fechado, intensidades extremamente baixas de radiação difusa são previsiveis para a maior parte do dia, sendo mais difícil afirmar a freqüência, duração, intensidade e qualidade da radiação direta (Chazdon \& Fetcher, 1984).

A qualidade da luz é um fator ambiental crítico e influi em todas as etapas do desenvolvimento de uma planta, desde a germinação até a reprodução. Assim, a capacidade fotossintética e as taxas de crescimento das espécies também são influenciadas pela qualidade da luz. Haan ${ }^{1}$ (1988) citado por Bernardes et al. (1996), reportou alguns benefícios da sombra durante o desenvolvimento inicial da pupunheira no campo. Villachica (1996b) afirma que devido ao seu rápido crescimento inicial, a pupunheira só pode ser associada aos cultivos anuais no primeiro ano, beneficiando-se da sombra desses cultivos nos primeiros meses depois do transplante. Silva (1998), utilizou cobertura feita com folhas de palmeira ou sombrite, atenuando a luminosidade para $50 \%$, para que as mudas de pupunheira em viveiro apresentassem desenvolvimento ideal para seu posterior plantio no campo. De outro modo, Gernek et al. (1981) 
verificaram que pupunheiras sob moderada sombra de plantas de Muntingia calabura, uma árvore de sombra usada em cultivo de Euterpe edulis, apresentaram um crescimento mais lento. Bernardes et al. (1996) observaram muitas falhas na germinação de sementes de pupunheira em condições de céu aberto, principalmente devido as baixas temperaturas ocorridas no período de outono e inverno, quando estas se encontravam no viveiro. Os mesmos autores constataram que a sombra provocada por um sombrite que permitia a transmissão de $60 \%$ da luz incidente, foi o tratamento que apresentou maior porcentagem de emergência e desenvolvimento inicial das plantas.

A direção da luz também é de suma importância, pois os períodos de luz direta e sua intensidade são determinados principalmente pelo ângulo da penetração solar por aberturas no dossel, na relação com a posição da folha ou da planta. Em geral, a forma da copa das palmeiras modifica-se um pouco em função de cada espécie. Ela é determinada por um número de variáveis, incluindo filotaxia, número, tamanho e flexibilidade das folhas (Tomlinson \& Jeffrey, 1990). O tamanho da copa das palmeiras juntamente com o diâmetro do seu tronco são proporcionais. As pupunheiras possuem uma copa de tamanho estável a partir do quarto ano permitindo que ao se fazer medições de índice de área foliar (IAF) encontrem-se valores relativamente altos. Esse IAF tem relação direta com a produtividade e com a biomassa (Wandelli \& Marques Filho, 1999).

\subsection{SAF e radiação solar}

O potencial agronômico de uma planta é a sua capacidade de produção em um ambiente determinado pela energia radiante disponível, pela variação em absorção de dióxido de carbono e pela temperatura do ar desde que todos os outros fatores que afetam o crescimento tenham sido otimizados.

O sol é a principal fonte de energia responsável pelos processos físicos, químicos e biológicos que se desenvolvem na Terra (Reichardt, 1993). 
A energia solar que chega à Terra compõem-se por radiações de diferentes comprimentos de onda, que variam de 200 a $4000 \mathrm{~nm}$.

A radiação solar que atinge a superficie terrestre, chamada de radiação global, consiste em duas partes: radiação solar direta e radiação difusa. $A$ radiação direta atinge a superfície da Terra sem que haja qualquer interação durante sua passagem pela atmosfera e representa em média $25 \%$ da radiação que atinge o topo da atmosfera. Deste modo, a radiação difusa assume grande importância como fornecedora de energia para as plantas, devido a sua quantidade que atinge a superfície da Terra, em muitas situações maior ou igual a da radiação direta, e por não ter dependência angular, conseguindo atingir o interior das copas e as partes interiores do dossel de uma forma mais homogênea, principalmente em dias nublados. A intensidade da radiação difusa depende da latitude, da altitude, do ângulo solar, da nebulosidade e da turbidez da atmosfera (Bernardes, 1987). No estudo da ação da luz sobre as plantas, ressaltam-se três fatores básicos: a intensidade da luz, a qualidade da luz e o tempo de exposição da planta em relação à luz. Considera-se ainda, que existe um ótimo de radiação solar para o crescimento de cada espécie vegetal e que para muitas espécies este ótimo é menor que a intensidade total diária de insolação natural (Garner \& Allard, 1920).

A radiação absorvida pelas folhas pode ser separada em radiação direta, radiação difusa na atmosfera e radiação difusa na copa ou no dossel, sendo que a quantidade de radiação que atinge as folhas sombreadas pode ser a soma dos dois últimos. Entretanto, nem toda a radiação que atinge as plantas promove algum efeito fisiológico. A radiação fisiologicamente ativa (PAI) é aquela que possui comprimento de onda capaz de induzir respostas fisiológicas nas plantas. A radiação fotossinteticamente ativa (PAR) representa a energia disponível para a fotossíntese, aproximadamente definida pelos limites de 400 a $700 \mathrm{~nm}$ do espectro (Bernardes, 1987).

A copa das plantas tem um papel importante no crescimento e na produtividade. A eficiência fotossintética de uma copa é afetada pela taxa 
fotossintética por unidade de área foliar e pela forma como a radiaçäo solar é interceptada pela copa, sendo importante sua arquitetura e dimensão. Segundo Tomlinson \& Jeffrey (1990), em uma floresta a porcentagem de radiação que chega ao solo é menor que $1 \%$ do que recebe o dossel das palmeiras. O índice de área foliar (IAF) e a duração da área foliar são os fatores mais importantes que determinam a produção de fitomassa $e$, conseqüentemente, do crescimento das plantas. A competição por luz é, portanto, a primeira limitação em SAFs quando a água e os nutrientes estão disponíveis. Por isso, entender como os SAFs utilizam os recursos disponíveis é fundamental para o estabelecimento de combinações de espécies, arranjo da plantação, densidade de plantio e manejo adequado para diferentes localidades (Bernardes et al., 1996).

No arranjo espacial da plantação, a forma na qual as plantas são distribuídas, afeta o seu crescimento. Em geral espaçamentos mais regulares, como os quadrangulares ou triangulares, são os melhores. Em contrapartida, os tratos culturais e o manejo da cultura ficam facilitados por espaçamentos em linhas (Bernardes \& Viccario, 1986). Pereira (1989) afirmou que o índice de colheita (IC) decresce com o aumento da população em virtude de adaptações morfológicas das plantas. Em condição de forte competição por luz ou sombreamento excessivo o IC é reduzido. Bernardes et al. (1998a) observaram uma diminuição no IC de plantas de milho cultivadas sob copas de seringueira adultas onde a irradiância era de aproximadamente $40 \%$ daquela de campo aberto.

Em SAFs há um efeito dominante do sombreamento causado pelas árvores (Monteith et al., 1991), promovendo redução do crescimento e da produção das culturas abaixo, conforme observado por Chong et al., (1991) para plantas forrageiras, por Bernardes et al., (1997, 1998b, 1998c e 2000) para soja, milho, cana-de-açúcar e arroz e por Righi \& Bernardes (1999) para feijoeiro. Entretanto, a combinação de espécies, que apresentem complementariedade na utilização da radiação, pode levar tais SAFs a serem 
mais eficientes do que os monocultivos de seus componentes (Castro \& Bernardes, 2001). Embora espere-se que a radiação seja o principal fator envolvido nas interações entre os componentes de um SAF, deve-se considerar que em condição de campo, outros fatores climáticos e edáficos afetam essas interações e trazem alguma dificuldade para quantificar o efeito isolado do sombreamento.

\subsection{Modelagem de radiação solar em SAF}

Os modelos matemáticos são descrições simplificadas de sistemas com limites definidos. São construídos para o melhor entendimento do seu funcionamento e interações entre fatores de produção e componentes, permitindo a quantificação dos elementos de maior interesse, estabelecendo-se equações que calculem essas relações. Para tal, é necessário a seleção dos componentes e processos chaves. Os modelos permitem a previsão do desempenho dos sistemas estudados, e são particularmente vantajosos, em relação a estudos puramente empíricos, para avaliação de sistemas de difícil reprodução experimental, como é o caso de SAFs (Bernardes et al., 1998b e Castro \& Bernardes, 2001).

Diversos estudos têm sido feitos para simular o regime de radiação em copas de plantas. Pukkula \& Kuuluvainen (1987) criaram modelo matemático que simula a radiação direta acima e abaixo do dossel de florestas com espaçamentos e copas desuniformes. Já o modelo FORFLUX2 (Bartelink, 1996) inclui o cálculo da radiação difusa. Knevel (1993) desenvolveu o modelo TREESHA para calcular o sombreamento causado por árvores isoladas. Esses modelos complexos demandam grande número de parâmetros e tempo de cálculo.

Assumindo algumas simplificações, pode-se lançar mão de modelos com menos parâmetros e mais simples de processamento de cálculo. Esse é o caso do primeiro deles, apresentado por Monsi \& Saeki (1953), onde a extinção da 
radiação através de um dossel uniformemente distribuído no espaço é calculada. A equação descrita por Goudriaan (1977) e avaliada por Gijzen \& Goudriaan (1989) calcula a irradiância que atinge a entrelinha de culturas em linhas, pode ser utilizada para o mesmo fim em sistemas agroflorestais em aléias (Bernardes et al. 1997 e 1998a), com algumas modificações. 


\section{MATERIAL E MÉTODOS}

\subsection{Caracterização da área experimental}

Este estudo foi desenvolvido no período de março de 1999 à agosto de 2000, na Estação Experimental da Embrapa Amazônia Ocidental, Manaus-AM, localizada no km 29 da Rodovia AM-010, Manaus/Itacoatiara em uma altitude em torno de $50 \mathrm{~m}$ acima do nível do mar, nas coordenadas $03^{\circ} 08^{\prime}$ de latitude Sul e $60^{\circ} 01^{\prime}$ de longitude Oeste.

Segundo a classificação climática de Köppen, o clima é do tipo AF, isto é, Clima Tropical Chuvoso e caracteriza-se por apresentar temperatura média do mês mais frio nunca inferior a $18^{\circ} \mathrm{C}$ e a precipitação do mês mais seco em torno de $100 \mathrm{~mm}$ (EMBRAPA, 1997). As Figuras 1, 2, 3, 4, 5 e 6 mostram dados agrometeorológicos de temperaturas máxima e mínima do ar, precipitação pluviométrica, insolação, umidade relativa do ar e evaporação nos anos em que o estudo foi desenvolvido comparados com a normal dos anos de 1971 até 1997.

O experimento foi implantado em uma área de terra firme, em um latossolo amarelo, textura muito argilosa, onde anteriormente havia sido cultivada seringueira (Hevea spp) por um período de cinco anos, sendo posteriormente abandonada por mais de seis anos. Passado este período, a vegetação foi então derrubada e queimada para a implantação do experimento. 


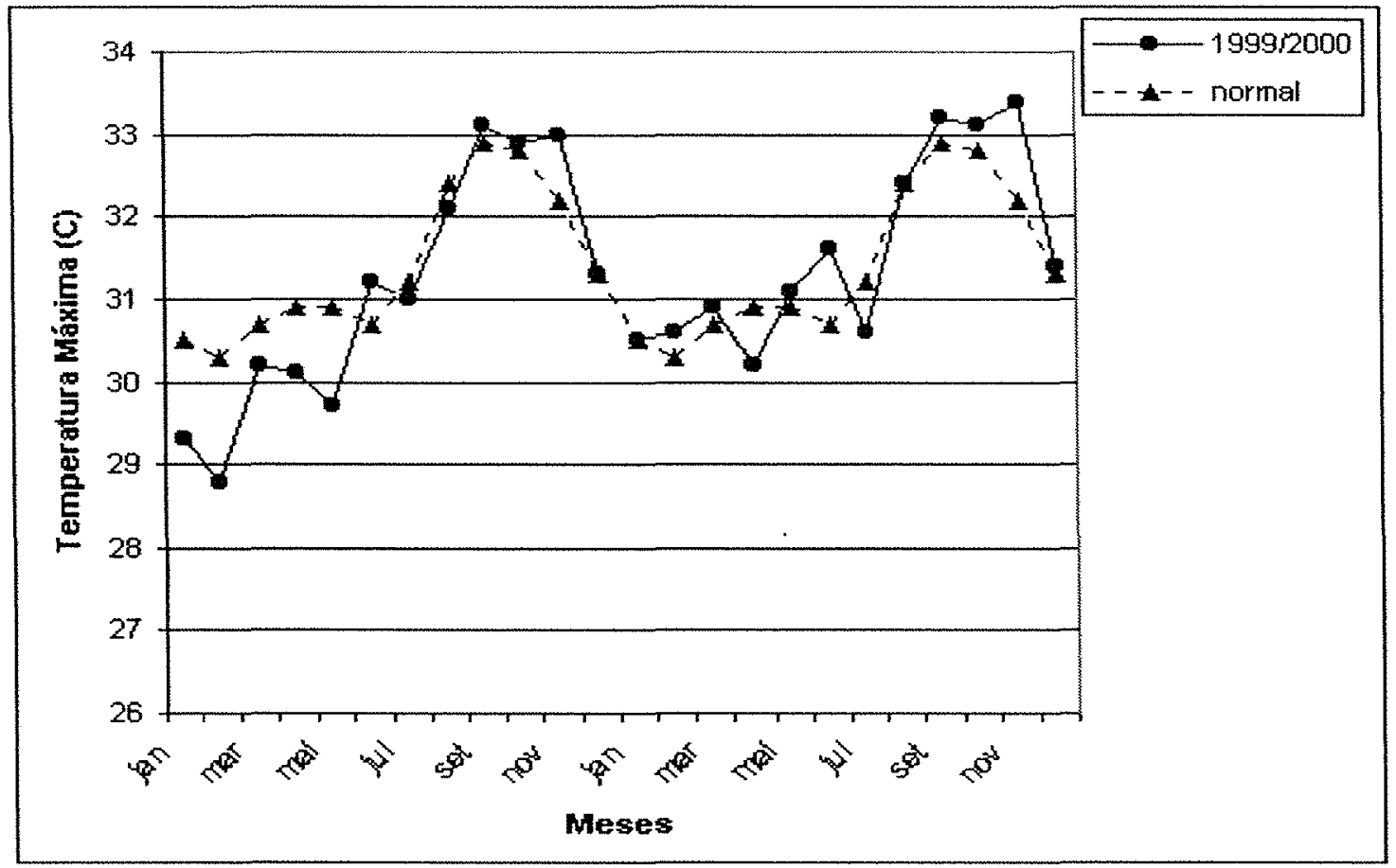

Figura 1- Temperaturas máximas do ar $\left({ }^{\circ} \mathrm{C}\right)$ dos anos de 1999 e 2000, comparadas à normal (1971-1997). Embrapa Amazônia Ocidental.

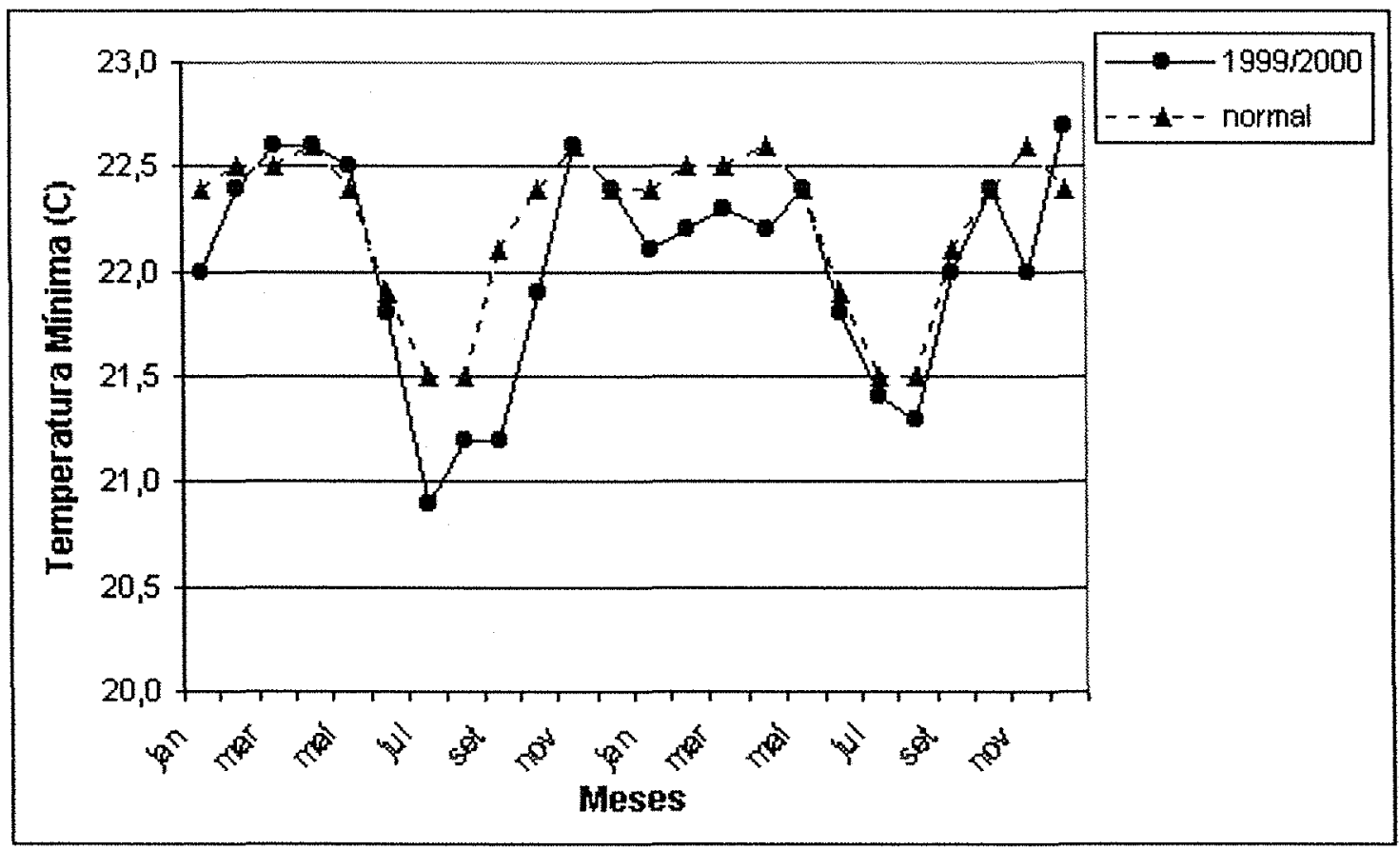

Figura 2 - Temperaturas mínimas do ar $\left({ }^{0} \mathrm{C}\right)$ dos anos de 1999 e 2000, comparadas à normal (1971-1997). Embrapa Amazônia Ocidental. 


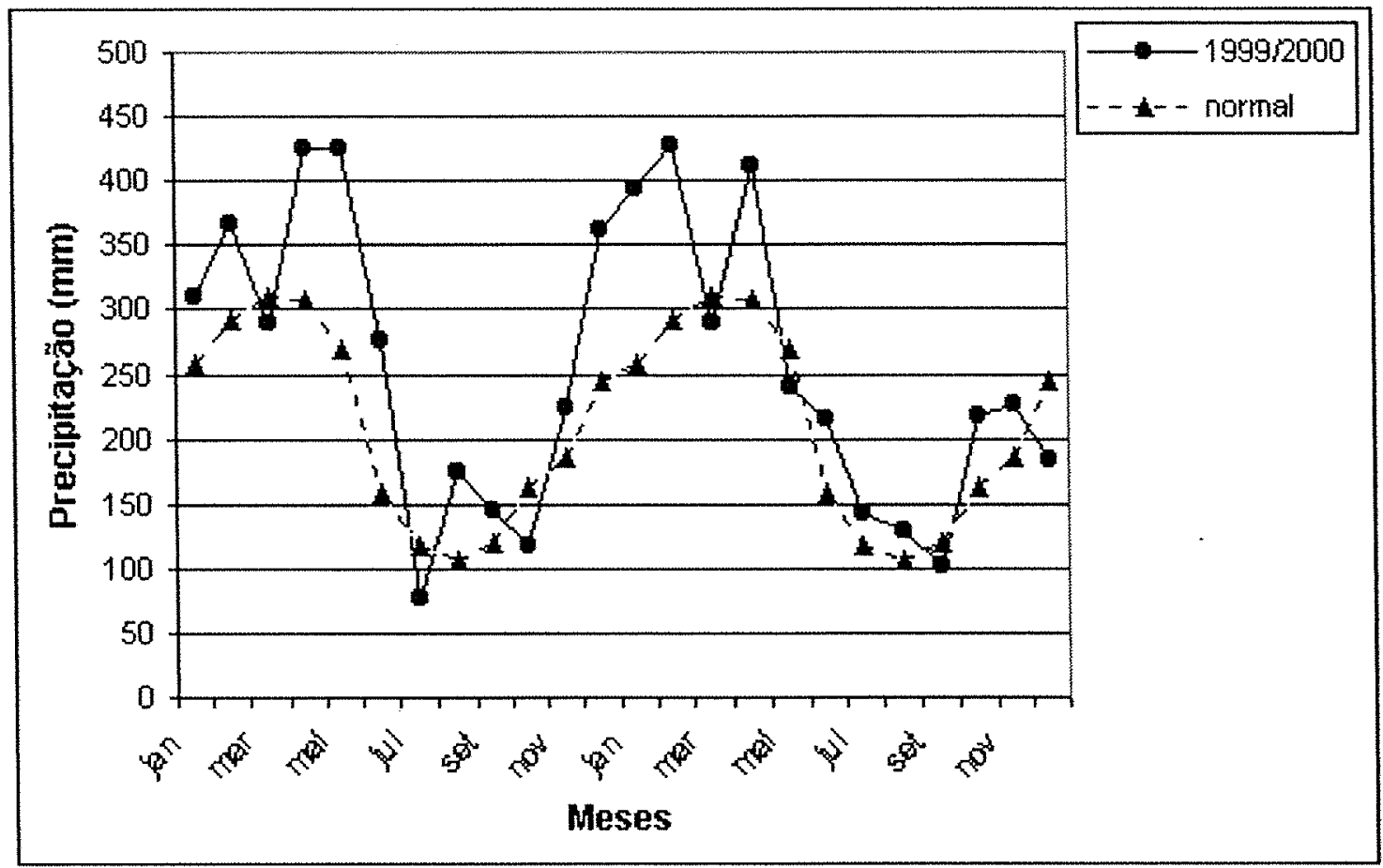

Figura 3 - Precipitação pluviométrica mensal (mm) dos anos de 1999 e 2000, comparadas à normal (1971-1997). Embrapa Amazônia Ocidental.

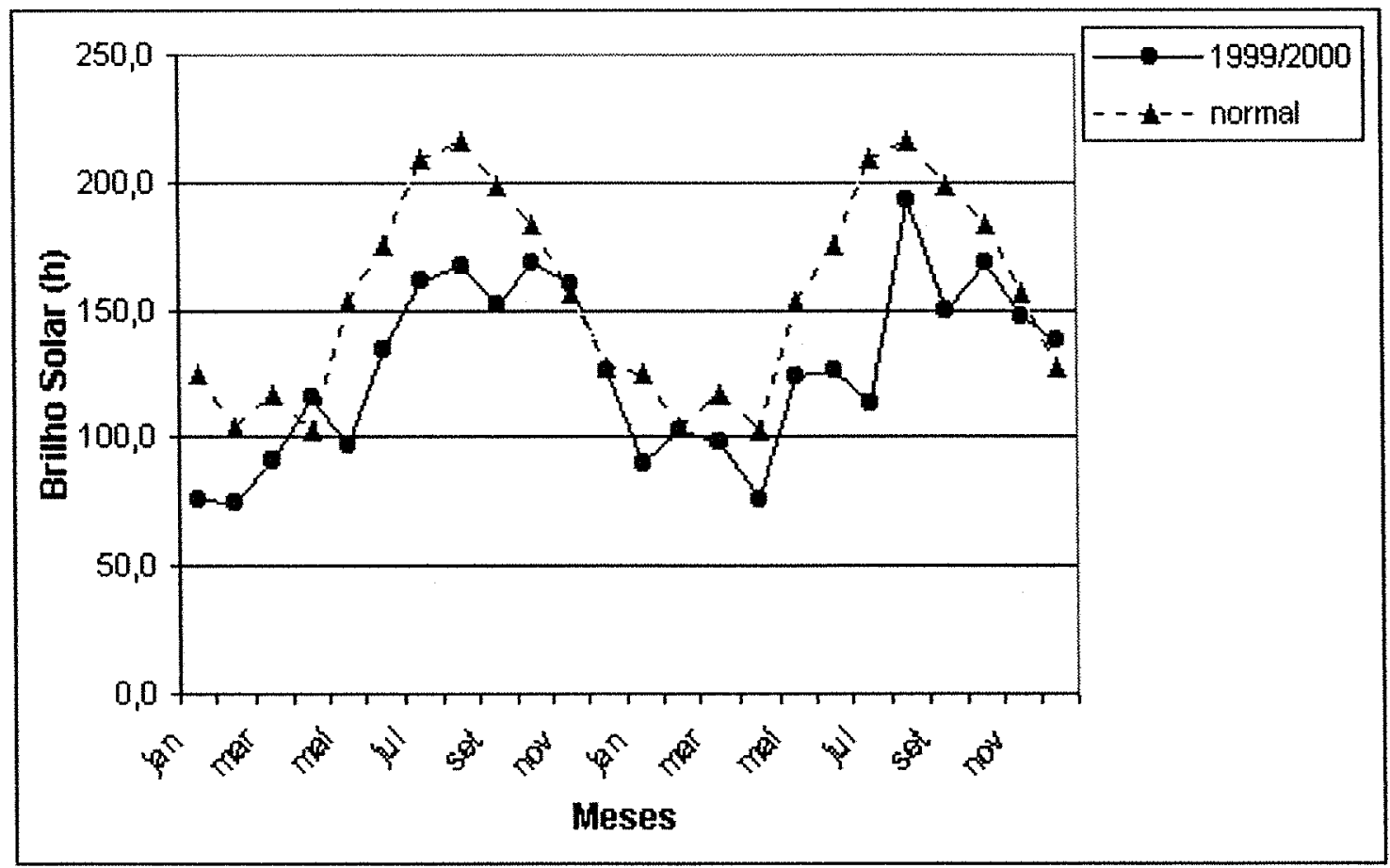

Figura 4 - Brilho solar mensal (h) dos anos de 1999 e 2000, comparadas à normal (1971-1997). Embrapa Amazônia Ocidental. 


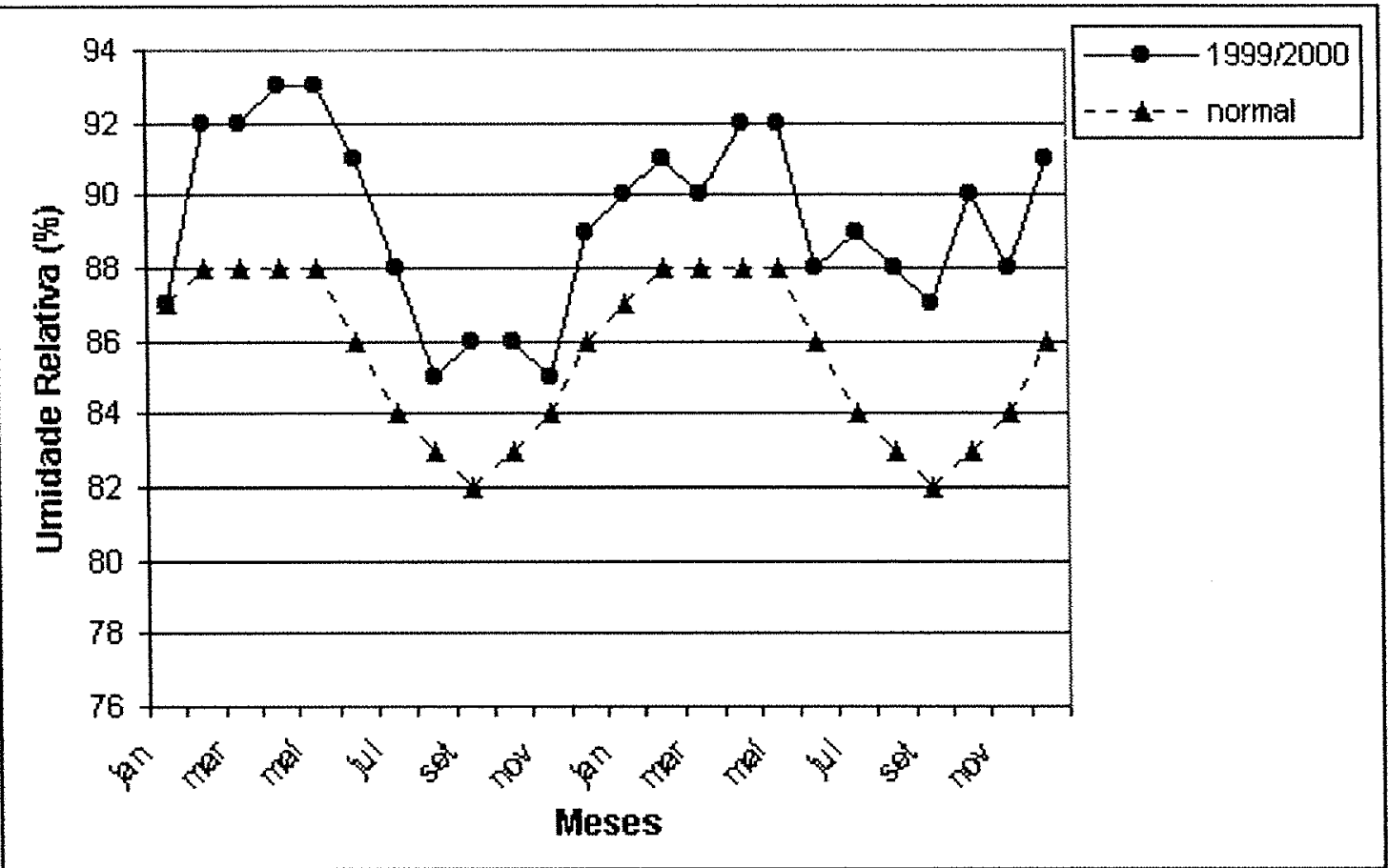

Figura 5 - Umidade relativa do ar (\%) dos anos de 1999 e 2000, comparadas à normal (1971-1997). Embrapa Amazônia Ocidental.

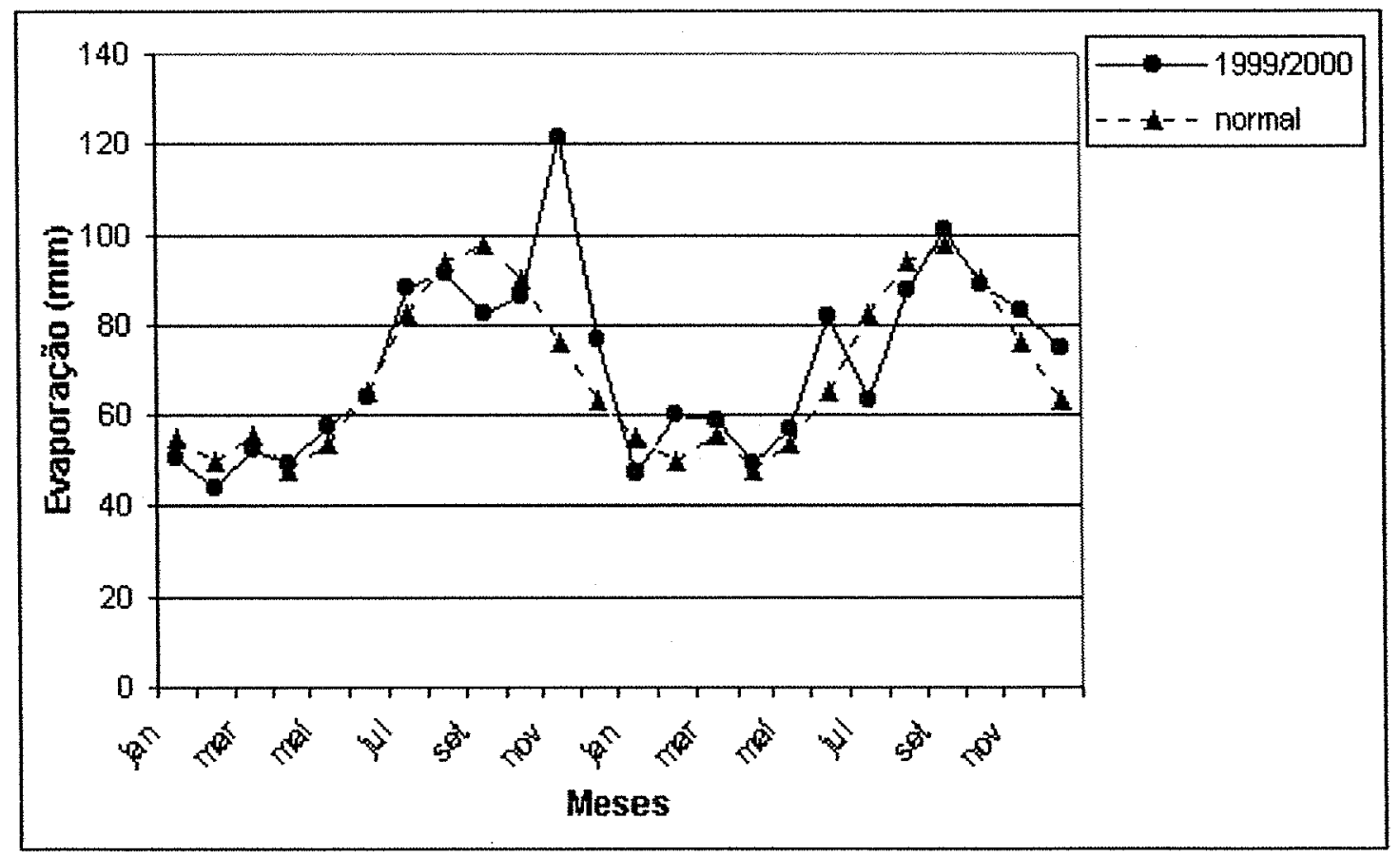

Figura 6 - Evaporação mensal (mm) dos anos de 1999 e 2000, comparadas à normal (1971-1997). Embrapa Amazônia Ocidental. 
O presente estudo é parte de um projeto de pesquisa maior, o projeto SHIFT (Studies on Human Impact on Forests and Floodplains in the Tropics) que envolve a comparação de quatro diferentes SAFs, quatro sistemas convencionais de monoculturas e uma área com a regeneração natural de capoeira (Figura 7). Os SAFs receberam niveis de fertilização de $100 \%$ ou de $30 \%$ do recomendado, com ou sem a inoculação com fungos micorrizicos vesicular-arbusculares (FMVAs), enquanto que os monocultivos receberam $100 \%$ de fertilização e não foram inoculados com os FMVAs. Nas entrelinhas foi plantada a puerária (Pueraria phaseoloides) como planta de cobertura.

Essa área experimental maior era composta por cinco blocos. Para o presente estudo, eliminou-se o bloco " $D$ " e selecionaram-se os SAFs que continham pupunheiras nos tratamentos que haviam recebido o nivel mais alto de fertilização e sem a inoculação por FMVA, comparando-os com o monocultivo de pupunheiras.

\subsection{Delineamento experimental}

O experimento foi conduzido em blocos casualizados com três tratamentos, repetidos quatro vezes. Cada parcela de amostragem de pupunheira foi formada por 12 plantas e cada parcela experimental foi constituída de uma área de $32,0 \mathrm{~m}$ de comprimento $\times 48,0 \mathrm{~m}$ de largura. Os três sistemas de cultivo constituíram os tratamentos: sistema 1 (SAF 1), sistema 2 (SAF 2) e monocultivo.

O SAF 1 foi constituído por uma combinação de três espécies perenes estando a linha com plantas de pupunheira em espaçamento de 2,0 m entre plantas e a 5,0 m entre as linhas adjacentes de seringueira e de cupuaçuzeiro. As linhas de pupunheira se alternavam apenas quanto ao destino da produção, se para extração de palmito ou para a colheita de frutos, como ilustra a Figura 8. 


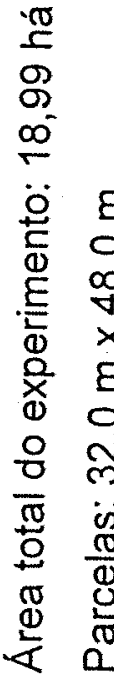

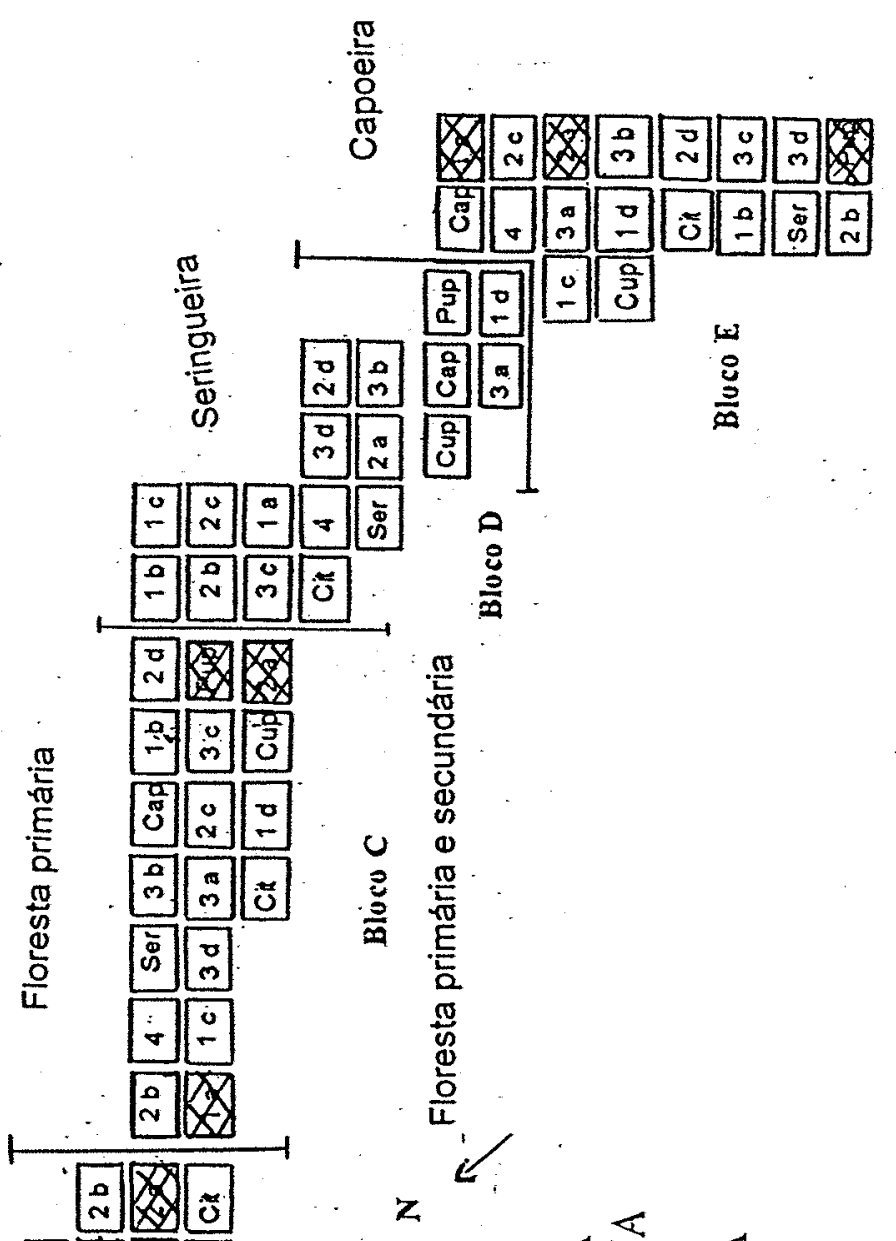

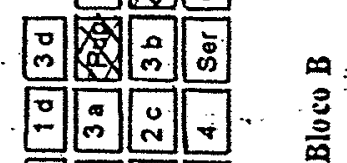

\begin{tabular}{lllll}
\hline 0 & 0 & 0 & 0 \\
0 & 0 & 0 \\
0
\end{tabular}

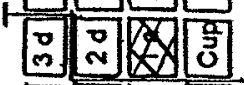

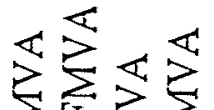

$\sum_{\text {S }} \sum_{\text {i }} \sum_{\text {II }}$

E

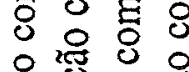

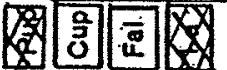

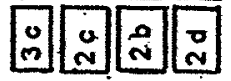

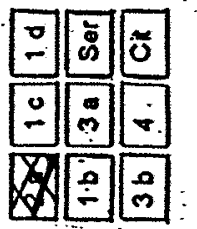

焉

这.

ख్

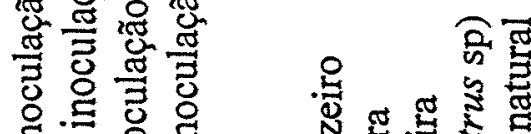

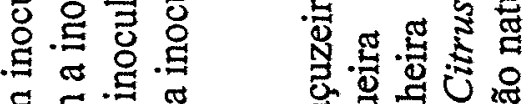

豆

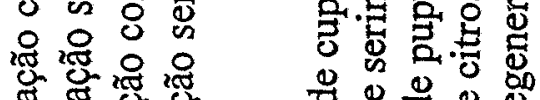

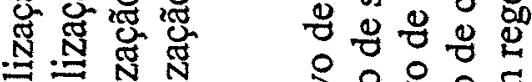

苏

แั

능 혼

ษ

을

E

듀

疍

ᄃ $\frac{0}{0}$

$\frac{\mathbb{2}}{0}$

$\frac{\text { L }}{\text { M }}$

.ึ)

$\frac{2}{2} \frac{8}{2}$

d

要

오

离

흐

음

त

흉 :

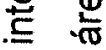

赵

面

중

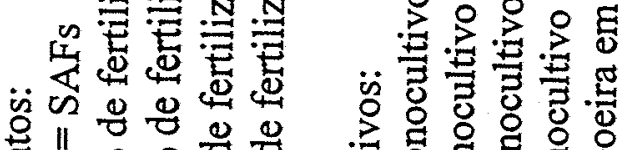

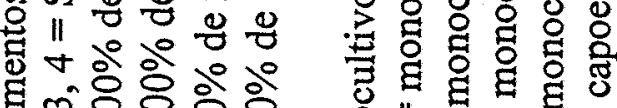

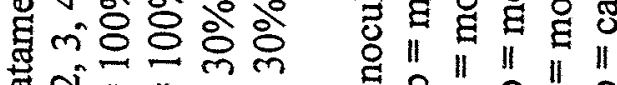

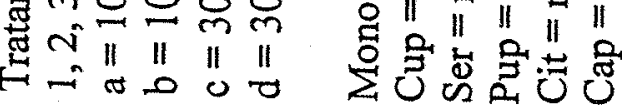

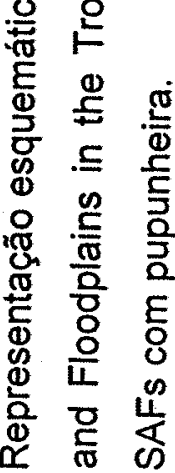

I

똔 
Foram realizadas avaliações em plantas alternadas de seringueira, medindo-se quatro das oito plantas totais da linha, enquanto foram avaliados todos os cinco cupuaçuzeiros da linha. As pupunheiras destinadas a produção de frutos também foram avaliadas alternando-se as plantas.

O SAF 2 foi constituido por uma combinação de quatro espécies perenes estando a linha com plantas de pupunheira em espaçamento de $2,0 \mathrm{~m}$ entre plantas e a 4,0 m entre as linhas adjacentes de castanheira-do-brasil e de cupuaçuzeiro e a 8,0 $\mathrm{m}$ de distância das linhas de urucuzeiro (Bixa orellana), como apresentado na Figura 9. Foram realizadas avaliações em duas castanheiras e dois cupuaçuzeiros em cada uma das linhas adjacentes à pupunheira e em plantas alternadas de urucuzeiro medindo-se três das oito plantas totais de cada uma das duas linhas.

No monocultivo, as pupunheiras estavam em espaçamento de $2,0 \times 2,0$ $m$ entre fileiras e entre plantas, respectivamente.

\subsection{Condução do experimento}

Todas as plantas perenes dos sistemas foram plantadas em 1993, sendo, portanto, plantas adultas na época do início do presente estudo. Estas continuaram recebendo os tratos culturais pertinentes, como fertilização e controle de plantas daninhas para que não ocorressem limitações ao seu crescimento.

As sementes das pupunheiras, oriundas de Yurimáguas, foram semeadas e conservadas em viveiro até o transplantio para o campo. As pupunheiras foram cortadas a partir dos 18 meses após o plantio para a extração do palmito, escolhendo-se as plantas que apresentavam seus estipes com diâmetro igual ou superior a $7 \mathrm{~cm}$ na altura do solo.

No presente estudo, as pupunheiras foram cortadas, aproximadamente, a cada quatro meses. A cada corte, precederam-se avaliações nestas árvores e nas árvores vizinhas das variáveis desejadas. 


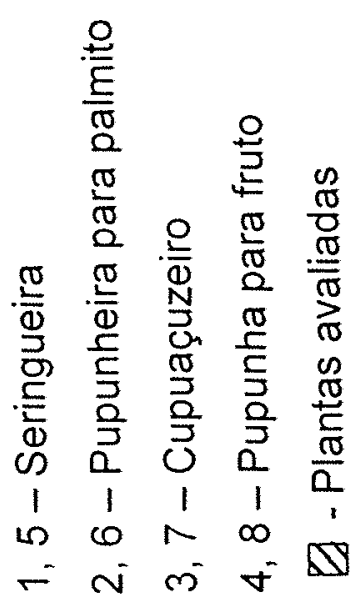

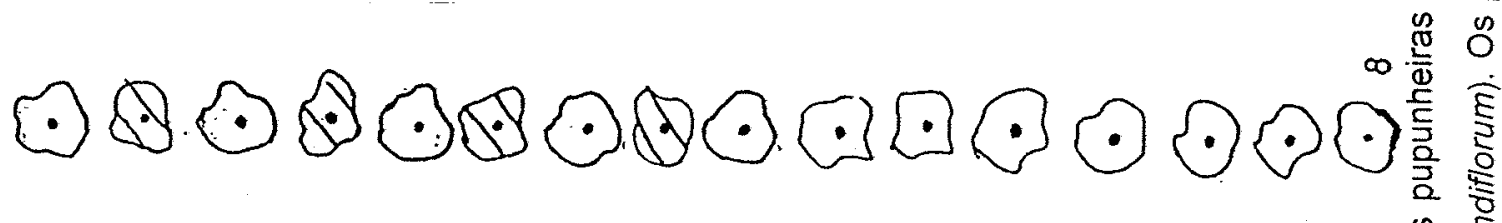
$\odot \odot \odot \odot \odot$

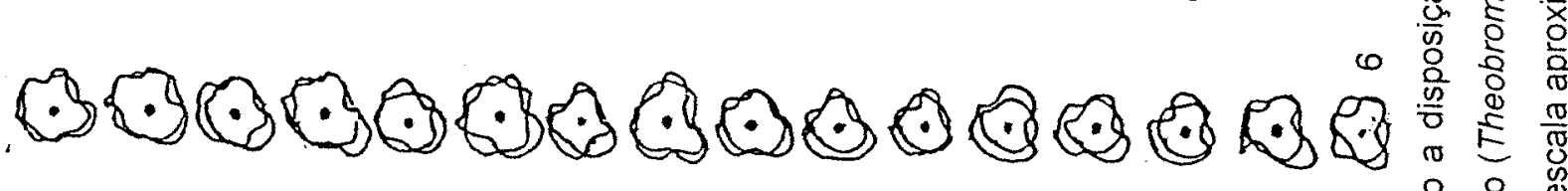

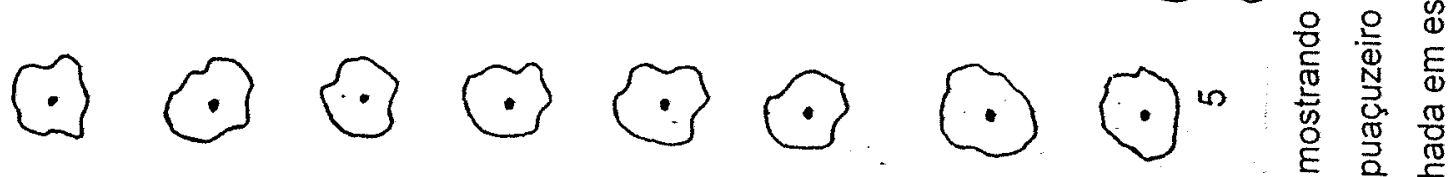

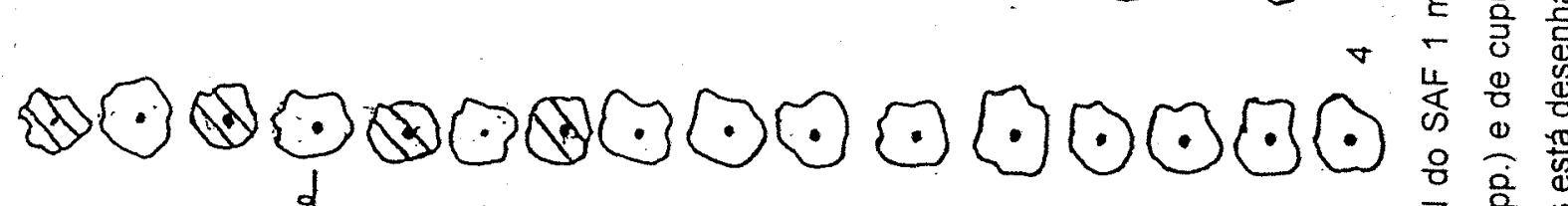

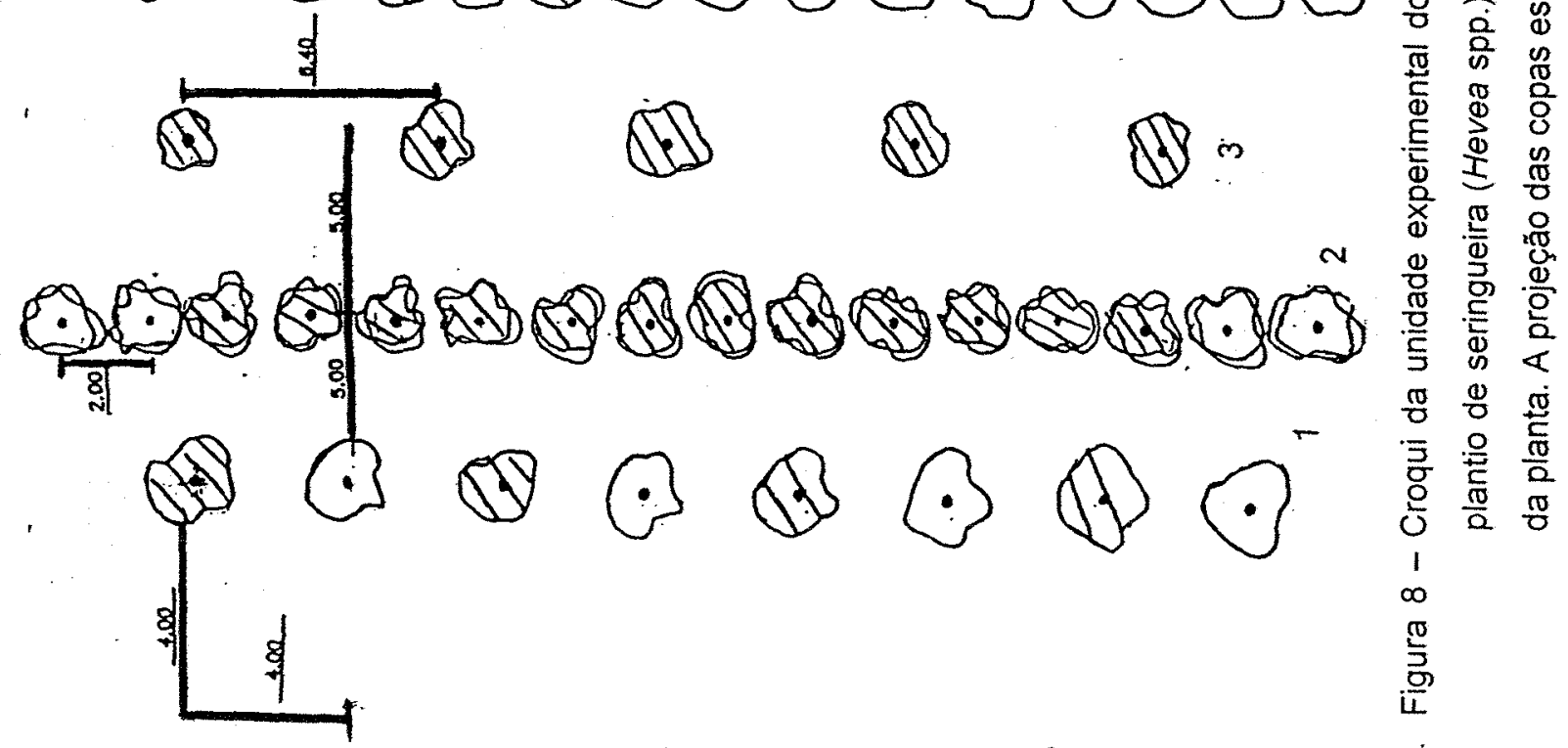




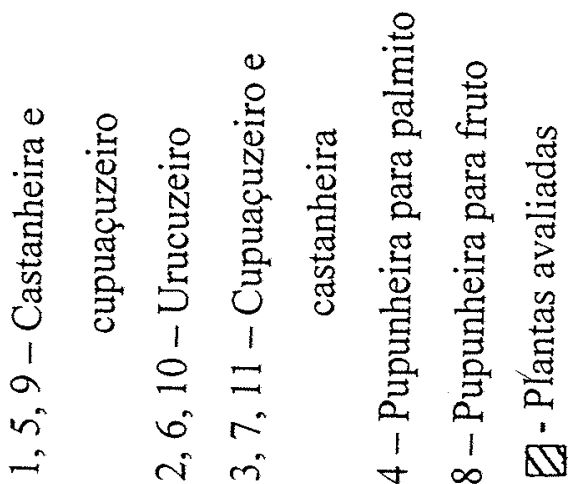

$0\{$.

$\odot$

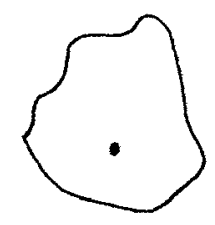

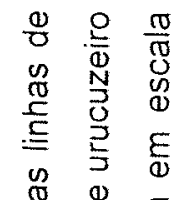

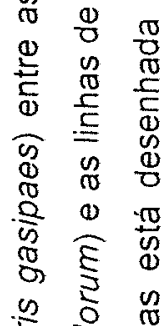

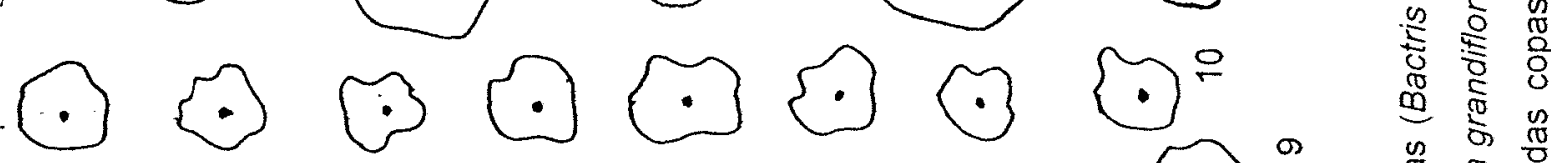

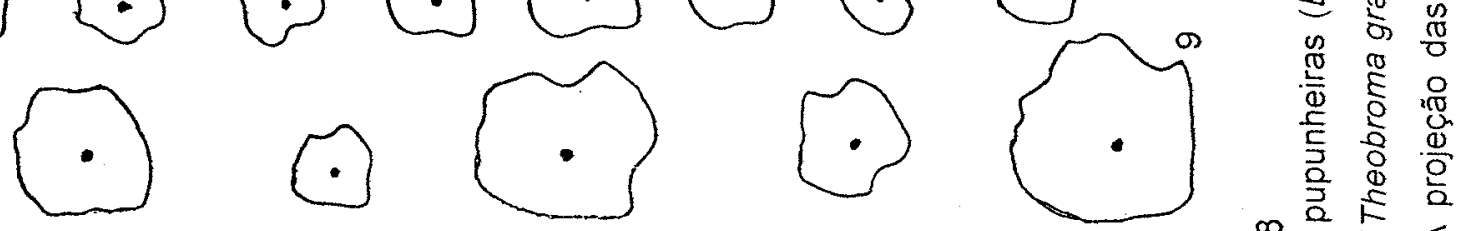

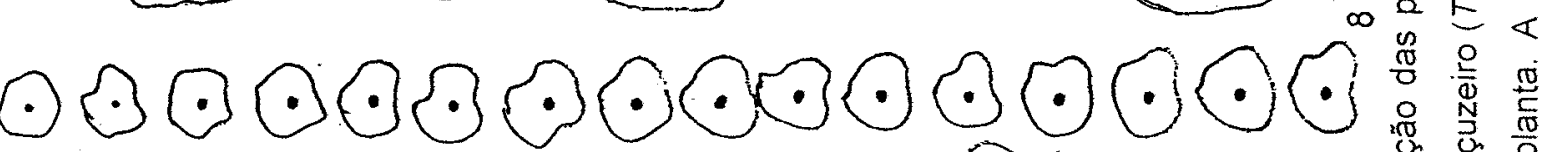

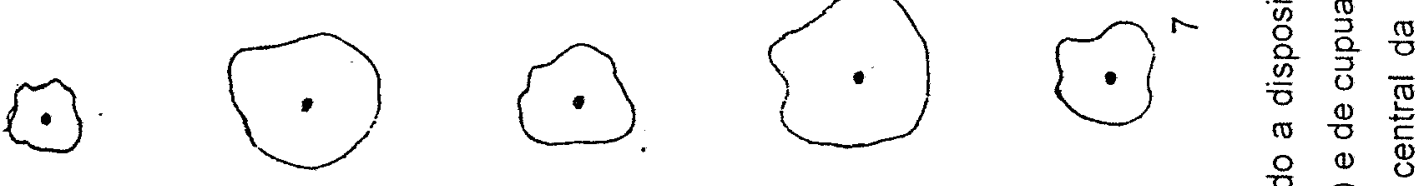

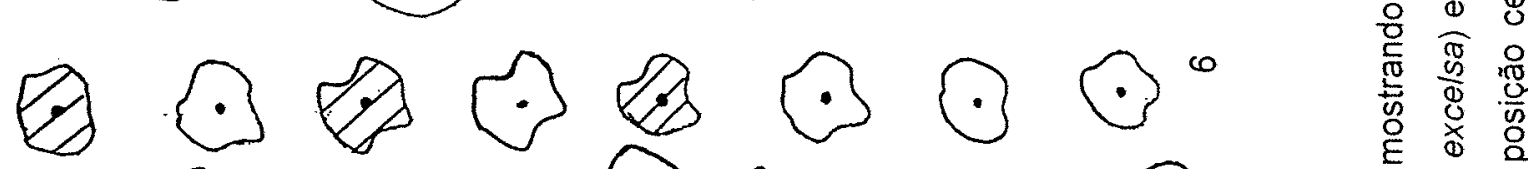
(2)

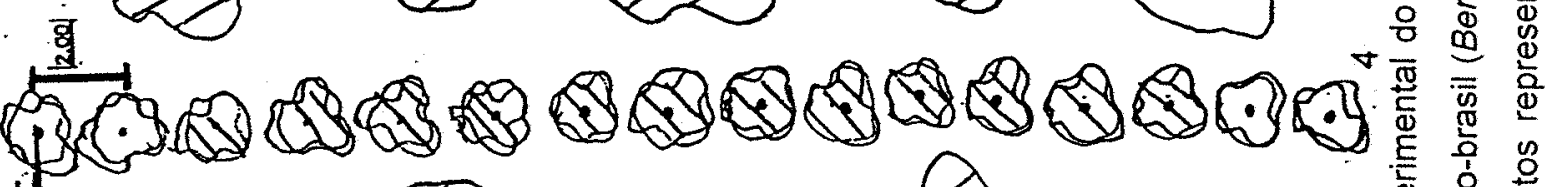

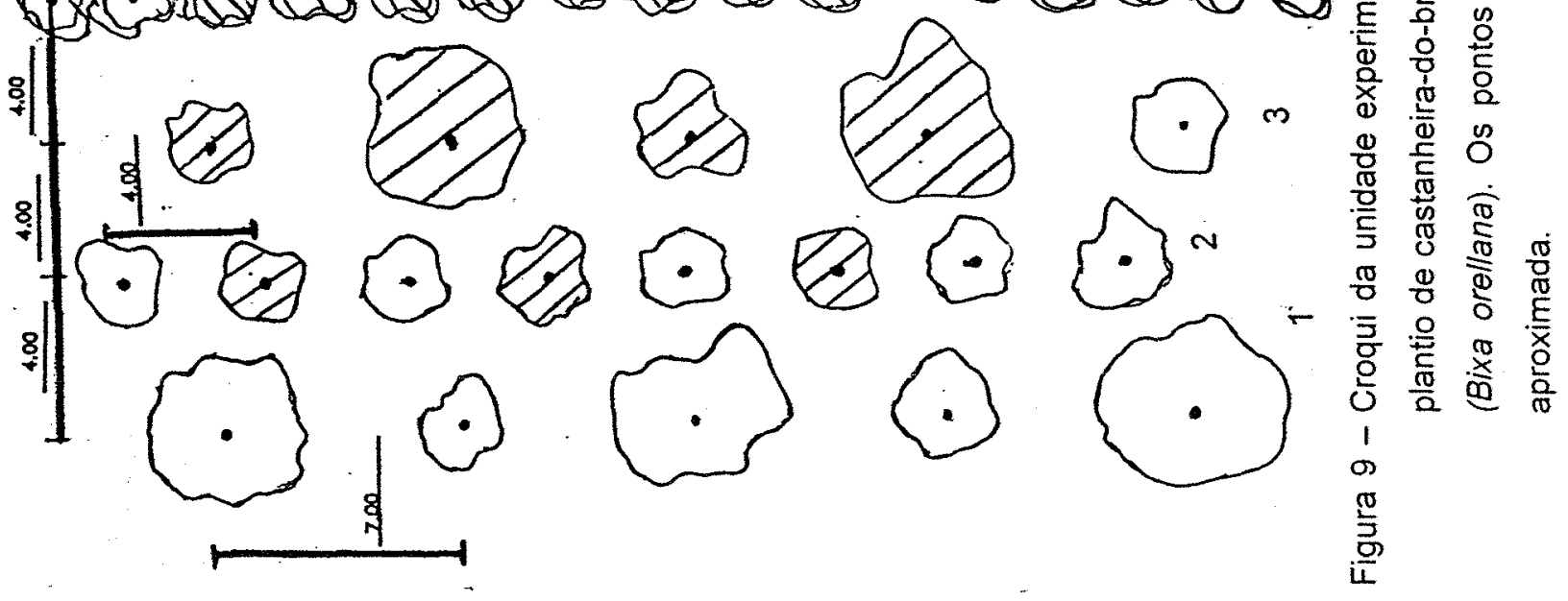




\subsection{Determinação experimental das variáveis avaliadas}

\subsubsection{Nas pupunheiras}

\subsubsection{Número de perfilhos}

O número de perfilhos foi contado em todas as 12 plantas avaliadas.

\subsubsection{Número de folhas}

O número de folhas por planta foi obtido pela contagem de folhas verdes de cada planta avaliada. As folhas amareladas, consideradas fotossinteticamente inativas, foram ignoradas.

\subsubsection{Massa da matéria seca das folhas e dos estipes}

A massa seca das folhas e dos estipes dos perfilhos colhidos, foi estimada nos momentos das colheitas, separando-se as folhas do estipe. $O$ material foi acondicionado em sacos de papel e levado a uma estufa com temperatura constante de $68^{\circ} \mathrm{C}$ e circulação de ar forçada, onde permaneceu até atingir massa constante. A avaliação deste parâmetro iniciou-se em agosto de 1999.

\subsubsection{Massa da matéria seca da parte aérea total das plantas}

A massa seca da parte aérea total foi obtida do somatório das folhas e dos estipes colhidos e estimados no momento da colheita, como descrito no item anterior.

\subsubsection{5 Índice de área foliar (IAF)}

O IAF foi estimado com o analisador de dossel LAI 2000 (LI-COR). Este equipamento realiza medições da atenuação da radiação que ocorre devido a presença das folhas, por comparação entre a luz medida sem e com a interferência das folhas. 


\subsubsection{Altura das plantas}

A altura total das plantas foi medida utilizando-se o altímetro de Haga, que mede altura por hipsometria. A altura da planta foi definida como a distância entre o ponto mais alto da copa e o solo. Apenas as plantas dos SAFs foram medidas.

\subsubsection{Diâmetro da copa}

O diâmetro da copa foi obtido pela média entre os diâmetros longitudinal e perpendicular à linha de plantio, medidos com o auxilio de uma trena. Apenas o diâmetro da copa das plantas dos SAFs foram medidos e o das plantas do monocultivo estimado pela sobreposição de folhas além da distância intermediária entre plantas no espaçamento, verificando-se que aquela era igual a $15 \%$ desse último. Deste modo, estimou-se o valor para $2,30 \mathrm{~m}$ de diâmetro para as pupunheiras no monocultivo.

\subsubsection{Número de palmitos colhidos}

A produção de palmitos por planta foi avaliada procedendo-se a contagem a cada colheita.

\subsubsection{Massa, diâmetro e comprimento do palmito}

A extração do palmito creme ou palmito comestivel foi realizada com a retirada cuidadosa das bainhas das folhas que o envolvem. O palmito creme total foi selecionado pelo aspecto de dureza, sendo refugada a parte que resistia ao corte sob leve pressão de faca de aço inoxidável bem afiada. Eram então avaliados a sua massa, diâmetro e comprimento. Vale ressaltar que após essas medições, os palmitos foram cortados em toletes de $9 \mathrm{~cm}$ de comprimento, tamanho usualmente utilizado pela indústria palmiteira para acondicionamento em frascos de vidro, denominando-se então palmito creme ou palmito envasável. Esta avaliação foi feita com a pesagem deste produto em balança, cujos resultados foram usados para estimar a massa da produção. $O$ 
diâmetro foi determinado com auxílio de um paquímetro e medindo o ponto central do palmito. O comprimento dos palmitos colhidos foi medido com auxílio de uma régua graduada.

\subsubsection{Massa dos resíduos industriais de palmito}

Após a extração do palmito, há uma sobra de pedaços de palmito creme, conhecida por resíduo basal que é uma porção do estipe imediatamente abaixo do meristema, e bastante tenro para ser consumido in natura e resíduo apical, que é composto por partes das folhas acima do último tolete completo de palmito, bastante tenra para ser consumidas in natura. Estas porções são ainda denominadas de resíduos industriais ou aparas, que podem ser também aproveitados na indústria e a sua avaliação procedeu-se através da pesagem. Normalmente são comercializados em cubinhos, picados ou em rodelas.

\subsubsection{Nas árvores vizinhas}

\subsubsection{Altura total e do tronco}

A altura total foi medida utilizando-se o altímetro de Haga, que mede altura por hipsometria. A altura da árvore foi definida como a distância entre o ponto mais alto da copa e o solo e a altura do tronco como a distância entre o ponto de inserção do ramo mais baixo e o solo (Bernardes, 1989).

\subsubsection{Comprimento da copa}

Foi medido pela diferença entre a altura total da árvore e a altura do tronco.

\subsubsection{Diâmetro da copa}

O diâmetro das copas das árvores, também foi medido de forma idêntica às pupunheiras para a extração de palmito, exceto nas seringueiras e nas pupunheiras para a extração de frutos, onde se utilizou um instrumento desenvolvido por Shepperd (1973). Este instrumento contém um espelho em 
um ângulo de $45^{\circ}$ com o plano horizontal que permite visualizar a borda da copa, estando o operador posicionado sob esta. A distância entre o instrumento e o tronco fornece o raio da copa, que somado ao raio do lado oposto fornece o diâmetro.

\subsubsection{Cálculo da disponibilidade de radiação para as pupunheiras}

Neste estudo, foi avaliado o crescimento das pupunheiras em SAF em função da disponibilidade de radiação solar. As árvores das linhas vizinhas formam uma barreira reduzindo a entrada total da radiação solar, fazendo-se necessário um cálculo para a determinação da quantidade de luz que as pupunheiras recebem. O modelo matemático original proposto por Goudrian (1977) e adaptado por Bernardes et al (1998b) e Castro \& Bernardes (1998) (1), foi utilizado para calcular a irradiância relativa $(\mathbf{I} \%=\mathbf{I r} / \mathbf{I}$ ) $)$ que atinge a copa das pupunheiras. O referido modelo simula a disponibilidade relativa de radiação luminosa, onde:

$I \%=\operatorname{Ir} / I 0=1 / 2 *\left\{\operatorname{sen}\left[\operatorname{arctg}\left(d_{1}-\left(\mathrm{CW}_{1}{ }^{2} / \mathrm{d}_{1}\right) / \mathrm{Hr}_{1}\right)\right]+\operatorname{sen}\left[\operatorname{arctg}\left(\left(\left(\mathrm{d}_{2}\right)-\left(\mathrm{cW}_{2}{ }^{2} / \mathrm{d}_{2}\right) / \mathrm{Hr}_{2}\right)\right]\right\}\right.$

em que, Ir = irradiância diária $\left(\mathrm{MJ} \cdot \mathrm{m}^{-2}\right)$ que atinge o topo da copa das pupunheiras a uma dada distância da linha de pupunheira com as duas linhas de árvores vizinhas $\left(d_{1}\right.$ e $\left.d_{2}\right) ; \mathbf{I}_{0}=$ irradiância diária (MJ.m $\left.\mathrm{m}^{-2}\right)$ numa superfície horizontal acima da copa das árvores; $\mathbf{d}_{1}$ e $\mathbf{d}_{2}=$ distância da pupunheira com as linhas de árvores vizinhas; $\mathbf{c W}=$ raio da copa $(\mathrm{m}) ; \mathrm{Hr}=$ altura $(\mathrm{m})$ relativa das árvores (1 e 2) obtida pela seguinte equação (2):

$$
\mathrm{Hr}=\mathrm{H}_{\text {ár }}-\mathrm{H}_{\text {pup }}
$$

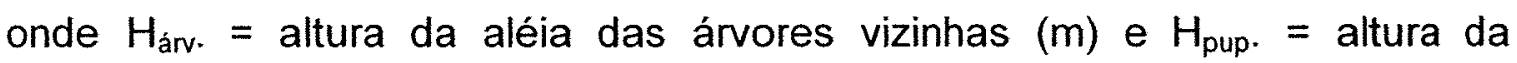
pupunheira. Para incluir a fração de luz que atravessa as aléias de árvores 
vizinhas no cálculo de disponibilidade de luz para as pupunheiras, o valor de $\mathrm{I} \%$ deve ser corrigido acrescentando-se o seu complemento, multiplicado pela permeabilidade das aléias à radiação $(\mathbf{p})$, conforme equação abaixo, postulada por Castro \& Bernardes (1998):

$$
\text { I corrigido } \%=I \%+[(100-1 \%) * p]
$$

As árvores que pela sua menor altura, não ultrapassaram o topo da barreira à radiação proporcionada pelas aléias maiores, não foram consideradas no cálculo de $1 \%$, mas somente para a estimativa da permeabilidade da aléia à radiação. Adicionalmente, estimou-se o valor de p para cada tipo de aléia e nas quatro épocas de avaliação. Para tanto, calculouse a área potencial de interceptação de radiação pela aléia (área pot.), obtida pela equação:

$$
\text { área pot. }=e^{e s p} \text {.ár. }{ }^{*} H_{\text {árv. }}
$$

em que: esp.ár. = espaçamento entre plantas na linha de árvores mais altas $(m)$ e $H_{a ̀ v}=$ altura média destas árvores $(m)$. A área preenchida pelas copas das árvores é calculada pela equação:

$$
\text { área preenchida }=\left[\left(C_{\text {árv }}{ }^{*} D_{\text {árv }}\right) * 0,7\right]
$$

em que: $\mathrm{CC}=$ comprimento da copa da árvore $(\mathrm{m}), \mathrm{DC}=$ diâmetro da copa desta árvore e $0,7=$ fator de correção do formato elíptico das copas. A permeabilidade especifica, ou seja, os vazios que existem entre as folhagens das copas e pelos quais é possivel a passagem da luz é calculado pela fórmula:

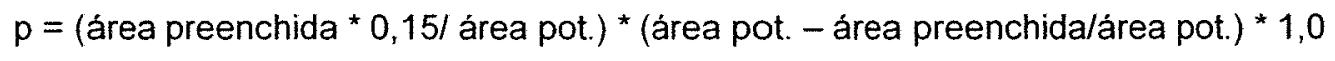


em que: $\mathbf{p}=$ permeabilidade específica e $0,15=$ valor assumido da proporção de luz que atravessa por entre as copas das árvores vizinhas e atinge as pupunheiras.

\subsection{Análise estatística}

Para a análise estatística realizaram-se análises de variância e testes de significância para os tratamentos e épocas de avaliação, para todas as variáveis. A análise foi em esquema de parcelas subdivididas no tempo. No quadro de médias está apresentado dois valores de coeficientes de variação (C.V.). O primeiro valor citado refere-se ao C.V. de tratamento (parcela) e o segundo, ao de épocas (subparcela). Utilizou-se para este procedimento os programa SANEST (sistema de análise estatística). Contrastes entre médias dos tratamentos foi comparada com teste de Tukey a $5 \%$ de probabilidade e apenas entre os tratamentos da variável produção total de palmito por planta, as médias foram comparadas a $10 \%$ de probabilidade. 


\section{RESULTADOS E DISCUSSÃO}

\subsection{Crescimento e biometria das pupunheiras para a produção de palmitos}

As pupunheiras estabelecidas nos três sistemas de cultivo, em cada época de avaliação, apresentaram comportamento semelhante estatisticamente, considerando-se as variáveis avaliadas. Entretanto, entre épocas de avaliação, as pupunheiras apresentaram algumas variáveis com médias estatisticamente diferentes. Exceção a variável índice de área foliar (IAF) das pupunheiras, que apresentou diferenças estatísticas entre os sistemas em estudo e entre as quatro épocas de avaliação, ocorrendo interação estatisticamente diferente entre os sistemas e épocas e para massa seca da parte aérea total que apresenta diferença significativa entre os SAFs na primeira época de avaliação.

\subsubsection{Número de perfilhos por planta}

$\mathrm{Na}$ Tabela 1, são apresentadas as médias entre os sistemas nas quatro épocas de avaliação para a variável número de perfilhos por planta. Comparando-se os sistemas, onde a densidade populacional de pupunheiras é diferente, pode-se observar que em cada época de avaliação as plantas apresentavam número de perfilhos semelhantes. Na Figura 10 estão representados os números médios de perfilhos por planta estabelecidos em cada sistema, em cada época de avaliação. Houve diferenças estaticamente significantes entre as épocas. As maiores quantidades de perfilhos por plantas ocorreram na terceira e quarta avaliações. Segundo Gomes et al. (1988), o 
número de perfilhos por planta ao longo do ciclo da cultura é fundamental, pois indica a capacidade de regeneração da planta, enfatizando que essa capacidade é afetada pela densidade de plantio, ou seja, maior tendência ao perfilhamento nas plantas em densidades menores. Neste trabalho, o número de perfilhos aumentou no decorrer do ciclo da cultura, mas não foi afetado pela densidade de planta, pois no monocultivo a densidade de pupunheiras é muito superior à densidade dos SAFs, apresentando em cada época de avaliação número médio de perfilhos semelhante. Esta é uma evidência de que o fator determinante do perfilhamento é a quantidade de luz incidente na base das pupunheiras. O monocultivo, apesar de possuir maior densidade de pupunheiras por área, estas não sofreram sombreamento, enquanto que os SAFs possuíam menor densidade de pupunheiras que sofriam sombreamento pelas árvores vizinhas. A semelhança no perfilhamento em todos os perfilhamentos leva a crer que houve uma compensação de menor densidade por sombreamento pelas árvores vizinhas quando em ambiente de luz na base das pupunheiras similar entre os tratamentos. O aumento no número de perfilhos na terceira avaliação parece ser devido a baixa precipitação pluviométrica, a baixa umidade relativa do ar, a elevada evaporação e a muito brilho solar (Figuras 3, 5, 6 e 4, respectivamente) ocorridos principalmente entre os meses de julho e outubro, meses que antecederam essa avaliação. Estas condições de clima propiciaram o estímulo a aceleração no desenvolvimento vegetativo, promovendo um maior perfilhamento das pupunheiras. Durante a quarta avaliação, observaram-se também um grande número de perfilhos por planta. Isto se deve ao fato que a maioria das pupunheiras avaliadas na época anterior, permaneceram no campo intactas, sem terem atingido o diâmetro adequado para o corte de palmito até a quarta avaliação, associado a um maior intervalo entre as avaliações da terceira e da quarta época, que foram de seis meses. Enquanto que o intervalo entre a segunda e terceira época foi apenas de quatro meses. 
Tabela 1. Número médio de perfilhos por planta comparado entre os três sistemas de cultivo e entre as épocas de avaliação.

\begin{tabular}{ccllll}
\hline Tratamentos & \multicolumn{5}{c}{ Épocas } \\
\cline { 2 - 6 } & mar/99 & ago/99 & dez/99 & jun/00 & Médias \\
\hline SAF 1 & 5,4 a B & 5,8 a B & 8,9 a A & 8,9 a A & 7,25 a \\
SAF 2 & 4,8 a B & 5,1 a B & 7,1 a A & 7,6 a A & 6,15 a \\
Monocultivo & 5,9 a B & 6,2 a B & 8,8 a A & 8,1 a A & 7,25 a \\
Médias & 5,4 B & 5,7 B & 8,3 A & 8,2 A & \\
C.V. (\%) & 11,84 & & & & \\
C.V. (\%) & 6,94 & & & & \\
\hline
\end{tabular}

- Médias seguidas de letras minúsculas iguais na vertical não diferem entre si pelo teste de Tukey a $5 \%$ de probabilidade.

- Médias seguidas de letras maiúsculas iguais na horizontal não diferem entre si pelo teste de Tukey a $5 \%$ de probabilidade.

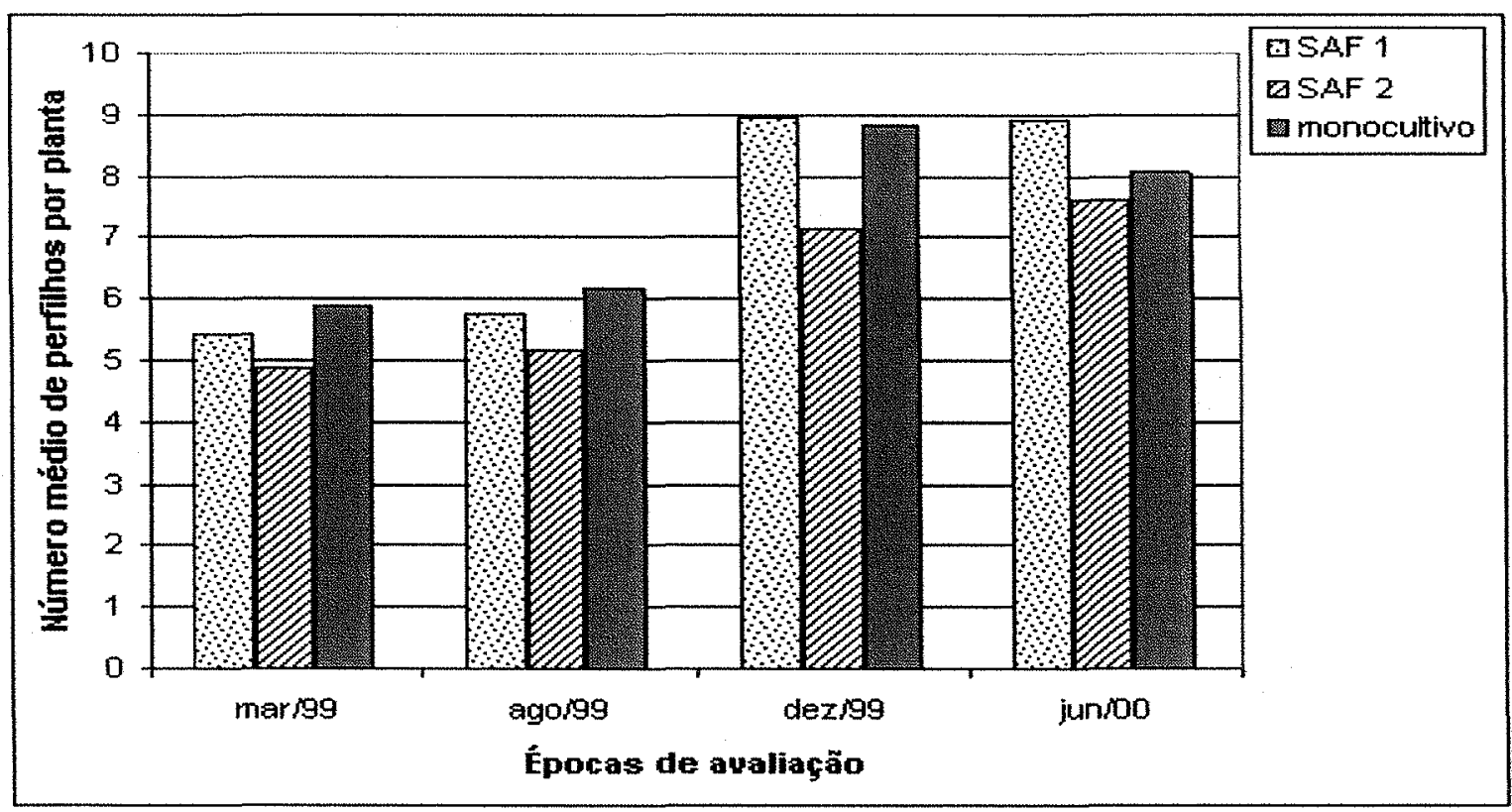

Figura 10 - Número médio de perfilhos por planta nos três sistemas estudados em cada época de avaliação. 


\subsubsection{Número de folhas por planta}

Os números médios de folhas por planta, nos três sistemas de cultivo e nas quatro épocas de avaliação estão apresentados na Tabela 2 e Figura 11. Não houve diferença estatística entre os sistemas. No entanto, ocorreram diferenças estatísticas significantes ao comparar-se as duas primeiras épocas em que foram realizadas as avaliações com as duas últimas. Na terceira e quarta avaliações, as plantas apresentaram-se com maior número de folhas.

$\mathrm{Na}$ pupunheira, o número de folhas vivas, verdes ou funcionais está diretamente relacionado com o número de folhas internas e, portanto, com a produção de palmito (Clement et al., 1988 e Bovi et al., 1992). Segundo Bovi (1998) e Ramos (1998), o número de folhas verdes por planta tende a decrescer com o aumento da densidade populacional e com a deficiência hídrica e nutricional. Os resultados deste estudo discordam com os autores, pois não houve redução do número de folhas por planta com o aumento da densidade de plantas. Entretanto, a compensação entre densidade e sombreamento, discutido no item 4.1.1 também deve ter provocado essa semelhança entre tratamentos. De forma semelhante ao número de perfilhos, 0 número médio de folhas por planta na terceira e na quarta épocas, foram superiores as duas épocas anteriores. Provavelmente a baixa precipitação pluviométrica e bastante brilho solar (Figuras 3 e 4) que antecederam esta avaliação estimularam a emissão foliar. Para a quarta avaliação, e da mesma forma que para o número de perfilhos, observaram-se que com a chegada das chuvas as plantas voltaram a crescer, justificando a constância do número médio de folhas. Este resultado está de acordo com Yuyama (1997), que em estudos com pupunheira em consorciação, observou que um maior número de folhas verdes, maior atividade fotossintética, e conseqüentemente, aumento da taxa de crescimento das plantas ocorreram após um periodo de baixa precipitação, com a chegada das chuvas. A estas considerações, junta-se o fato de ter havido um intervalo maior de avaliação entre essas duas últimas épocas. 
Tabela 2. Número médio de folhas por planta comparado entre os sistemas de cultivo e entre as épocas de avaliação.

\begin{tabular}{cccccc}
\hline Tratamentos & \multicolumn{5}{c}{ Épocas } \\
\cline { 2 - 6 } & mar/99 & ago/99 & dez/99 & jun/00 & médias \\
\hline SAF 1 & 17,6 a B & 18,7 a B & 31,4 a A & 28,8 a A & 24,1 a \\
SAF 2 & 15,4 a B & 17,5 a B & 24,0 a A & 25,3 a A & 20,5 a \\
Monocultivo & 20,6 a B & 22,5 a B & 27,1 a A & 24,7 a A & 23,7 a \\
Médias & 17,9 B & 19,6 B & 27,5 A & 26,3 A & \\
C.V. (\%) & 10,99 & & & & \\
C.V. (\%) & 8,83 & & & & \\
\hline
\end{tabular}

- Médias seguidas de letras minúsculas iguais na vertical não diferem entre si pelo teste de Tukey a $5 \%$ de probabilidade.

- Médias seguidas de letras maiúsculas iguais na horizontal não diferem entre si pelo teste de Tukey a $5 \%$ de probabilidade.

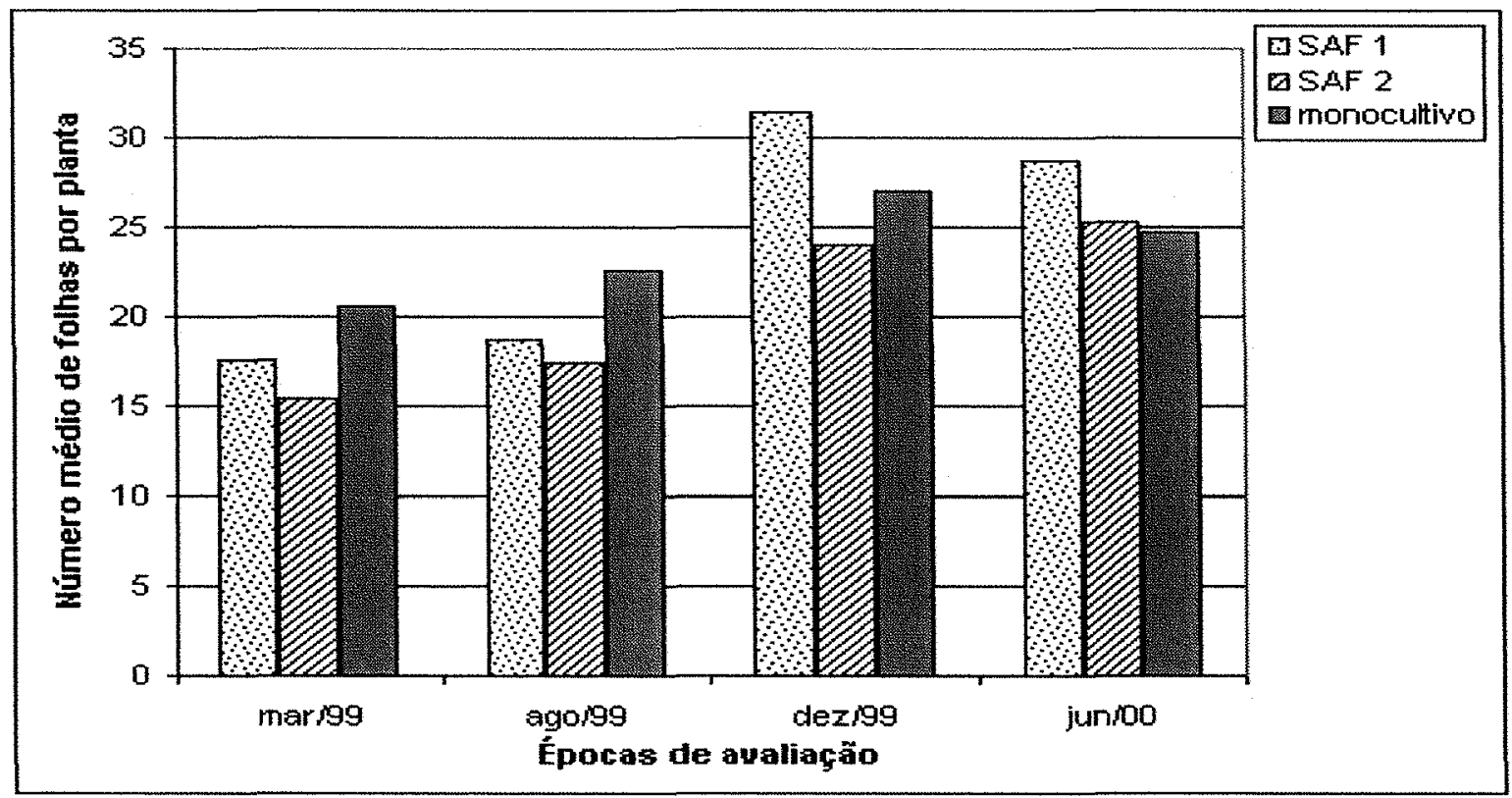

Figura 11 - Número médio de folhas por planta nos três sistemas estudados em cada época de avaliação. 


\subsubsection{Massa da matéria seca (MS) das folhas e dos estipes}

Não houve diferença estatística na massa da matéria seca das folhas e dos estipes das pupunheiras entre os sistemas em cada época de avaliação (Tabelas 3 e 4). Entretanto, pode-se verificar que houve diferença estatística para essas variáveis, ao compararem-se as épocas de avaliação (Tabelas 3 e 4 e Figuras 12 e 13), comprovando-se que a colheita realizada após os meses que ocorreu uma baixa precipitação, foi menor. Durante o período de baixa precipitação pluviométrica, houve um maior desenvolvimento vegetativo das pupunheiras havendo, portanto, uma baixa quantidade de plantas com diâmetro ideal para a colheita de palmitos, o que conseqüentemente, justificou a baixa produção de matéria seca.

Tabela 3. Médias da massa da matéria seca das folhas das plantas ( $\mathrm{kg} / \mathrm{planta)}$ comparadas entre sistemas de cultivo e entre as épocas de avaliação.

\begin{tabular}{ccccc}
\hline Tratamentos & \multicolumn{4}{c}{ Épocas } \\
\cline { 2 - 5 } & ago/99 & dez/99 & jun/00 & médias \\
\hline SAF 1 & 2,859 a A & 1,286 a B & 1,996 a AB & 2,047 a \\
SAF 2 & 2,772 a A & 1,300 a B & 1,969 a AB & 2,014 a \\
Monocultivo & 3,253 a A & 1,472 a B & 2,841 a AB & 2,522 a \\
Médias & $2,961 \mathrm{~A}$ & $1,353 \mathrm{~B}$ & $2,269 \mathrm{AB}$ & \\
C.V. $(\%)$ & 25,60 & & & \\
C.V. $(\%)$ & 31,88 & & & \\
\hline
\end{tabular}

- Médias seguidas de letras minúsculas iguais na vertical não diferem entre si pelo teste de Tukey a $5 \%$ de probabilidade.

- Médias seguidas de letras maiúsculas iguais na horizontal não diferem entre si pelo teste de Tukey a $5 \%$ de probabilidade. 


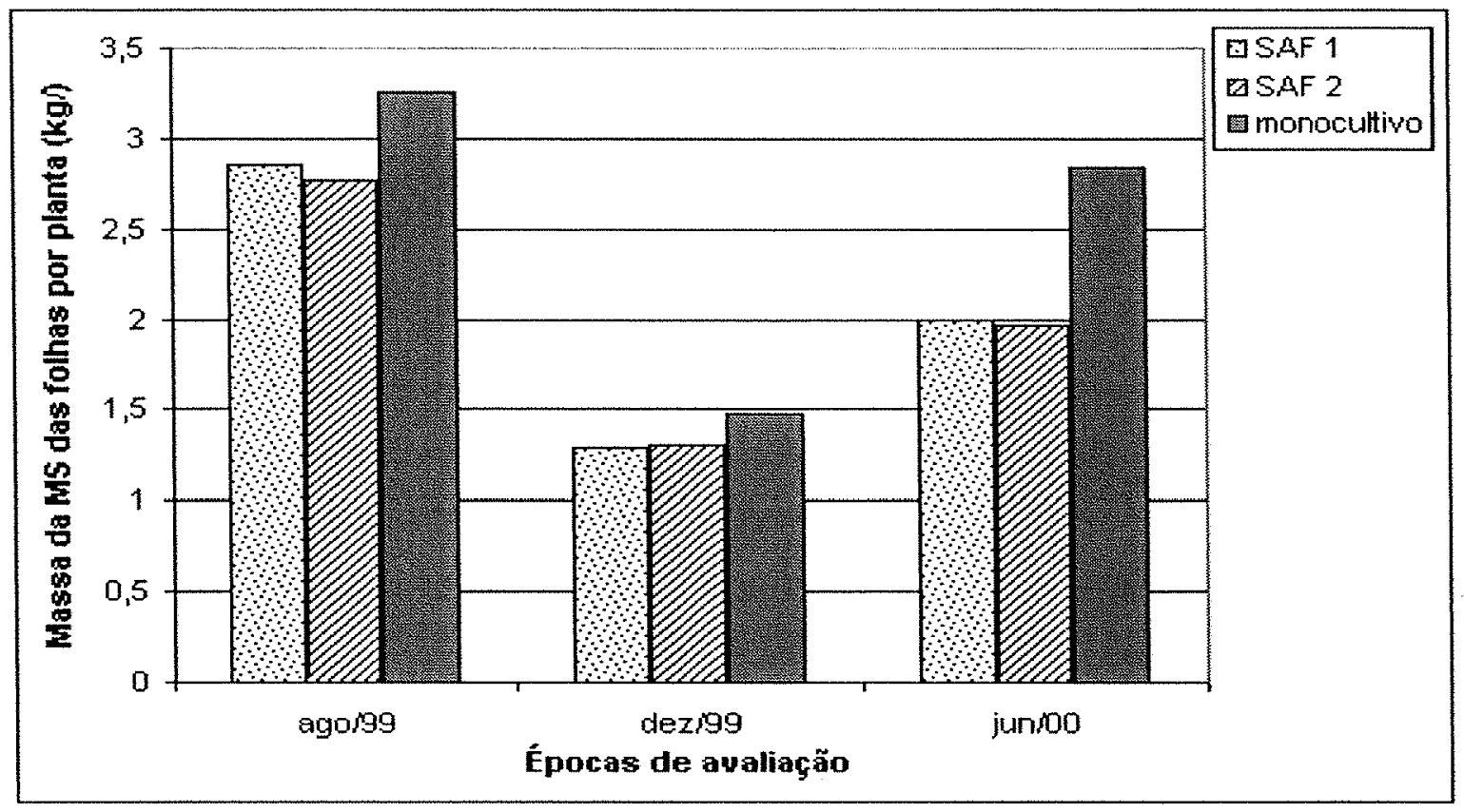

Figura 12 - Massa da matéria seca (MS) das folhas por planta (kg/planta) para os três sistemas estudados em cada época de avaliação.

Tabela 4. Médias da massa da matéria seca dos estipes das plantas ( $\mathrm{kg} / \mathrm{planta)}$ comparadas entre os sistemas de cultivo e entre as épocas de avaliação.

\begin{tabular}{ccccc}
\hline Tratamentos & \multicolumn{4}{c}{ Épocas } \\
\cline { 2 - 5 } & ago/99 & dez/99 & jun/00 & médias \\
\hline SAF 1 & 3,150 a A & 1,114 a B & 3,303 a A & 2,522 a \\
SAF 2 & 2,929 a A & 1,240 a B & 3,017 a A & 2,395 a \\
Monocultivo & 4,199 a A & 1,530 a B & 2,883 a A & 2,871 a \\
Médias & 3,426 A & 1,295 B & 3,068 A & \\
C.V. $(\%)$ & 19,80 & & & \\
C.V. $(\%)$ & 24,91 & & & \\
\hline
\end{tabular}

- Médias seguidas de letras minúsculas iguais na vertical não diferem entre si pelo teste de Tukey a $5 \%$ de probabilidade.

- Médias seguidas de letras maiúsculas iguais na horizontal não diferem entre si pelo teste de Tukey a $5 \%$ de probabilidade. 


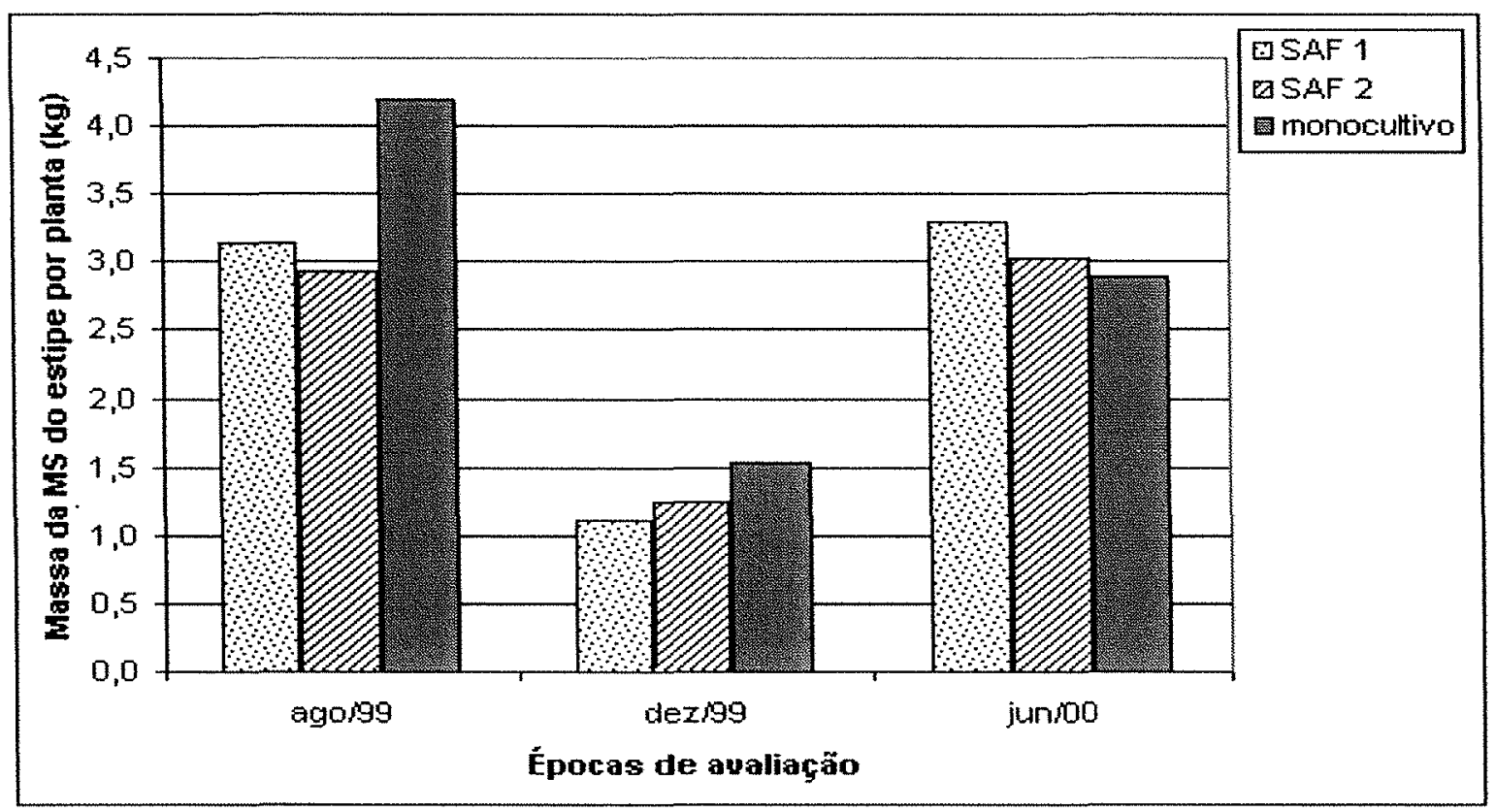

Figura 13 - Massa da matéria seca (MS) dos estipes por planta (kg/planta) para os três sistemas em cada época de avaliação.

\subsubsection{Massa da matéria seca (MS) da parte aérea total das plantas colhidas}

A Tabela 5 apresenta as médias da massa da matéria seca total da parte aérea das plantas colhidas. As médias entre os sistemas apresentaram comportamento semelhante durante a avaliação de dezembro/99 e de junho/00, onde os três sistemas mostraram-se significativamente iguais entre si. Entretanto, na avaliação realizada em agosto/99, o monocultivo foi significativamente superior aos demais. Ao comparar-se as épocas de avaliação, observou-se uma menor produção de matéria seca na terceira época, diferindo significativamente das demais (Figura 14). Nesta avaliação, condições climáticas, como baixa precipitação pluviométrica e muito brilho solar, provavelmente ocasionaram redução do metabolismo, reduzindo 
conseqüentemente, o crescimento e desenvolvimento das pupunheiras, não permitindo que estas estivessem em condições de corte, o que conseqüentemente, justificou a baixa produção de matéria seca.

A análise mostrou diferença estatística entre as épocas de avaliação, apenas quando realizaram-se os contrastes entre as médias a $10 \%$ de probabilidade.

Tabela 5. Médias da massa da matéria seca da parte aérea total das plantas ( $\mathrm{kg} / \mathrm{planta}$ ) comparadas entre os sistemas de cultivo e entre as épocas de avaliação.

\begin{tabular}{ccccc}
\hline Tratamentos & \multicolumn{4}{c}{ Épocas } \\
\cline { 2 - 5 } & ago/99 & dez/99 & jun/00 & médias \\
\hline SAF 1 & $6,009 \mathrm{~b} \mathrm{~A}$ & 2,400 a B & 5,299 a A & 4,569 a \\
SAF 2 & 5,701 b A & 2,540 a B & 4,986 a A & 4,409 a \\
Monocultivo & 7,452 a A & 3,002 a C & 5,724 a B & $5,393 \mathrm{~b}$ \\
Médias & 6,387 A & 2,647 B & 5,336 A & \\
C.V. $(\%)$ & 21,90 & & & \\
C.V. $(\%)$ & 26,31 & & & \\
\hline
\end{tabular}

- Médias seguidas de letras minúsculas iguais na vertical não diferem entre si pelo teste de Tukey a $5 \%$ de probabilidade.

- Médias seguidas de letras maiúsculas iguais na horizontal não diferem entre si pelo teste de Tukey a $5 \%$ de probabilidade. 


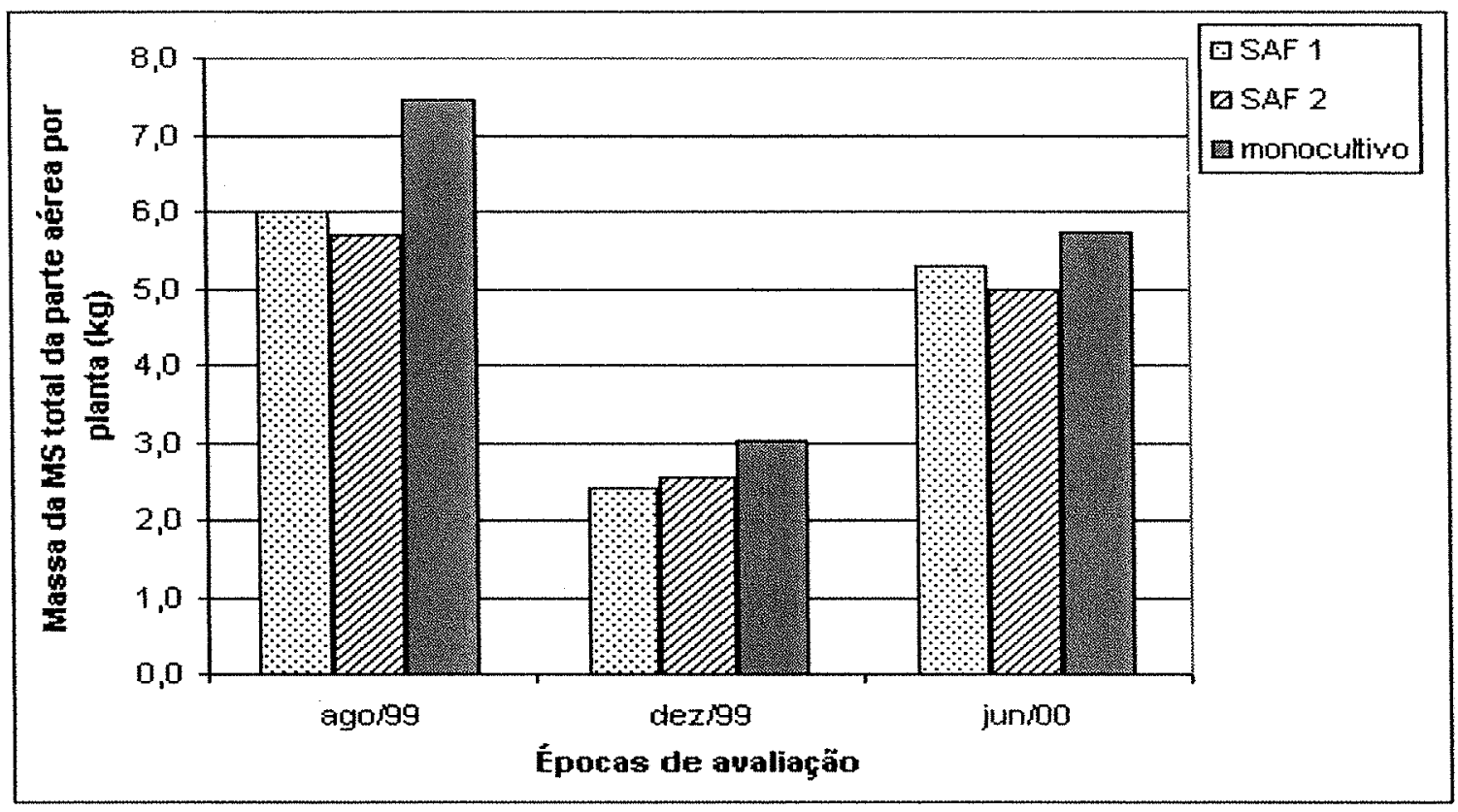

Figura 14 - Massa da matéria seca (MS) da parte aérea total das plantas ( $\mathrm{kg} / \mathrm{planta}$ ) para os três sistemas estudados em cada época de avaliação.

\subsection{5 Índice de área foliar (IAF) da planta}

Houve diferença significativa no índice de área foliar das pupunheiras entre os sistemas, exceto na segunda e quarta avaliações (Tabela 6). Nas diferentes épocas em que foram realizadas as avaliações, ocorreram variações nos IAF, havendo portanto, diferenças estatisticamente significantes (Figura 15).

Comparando-se os sistemas, pode-se observar que 0 monocultivo apresentou freqüentemente IAF superior aos SAFs, e estes, por sua vez, apresentaram IAF iguais. Na segunda avaliação, em agosto/99, todos os três sistemas mostraram-se semelhantes, porém o SAF 1 apresentou IAF ligeiramente superior. $\mathrm{Na}$ avaliação subseqüente, o monocultivo continuou 
apresentando IAF superior, enquanto os dois SAFs se mostraram semelhantes entre si. Na última avaliação, os três sistemas apresentaram IAF semelhantes.

Tabela 6. Médias do IAF $\left(\mathrm{m}^{2}\right.$ de folha $/ \mathrm{m}^{2}$ de área de solo) por planta comparadas entre os sistemas de cultivo e entre as épocas de avaliação.

\begin{tabular}{cccccc}
\hline Tratamentos & \multicolumn{5}{c}{ Épocas } \\
\cline { 2 - 6 } & mar/99 & ago/99 & dez/99 & jun/00 & Médias \\
\hline SAF 1 & $2,25 \mathrm{~b}$ A & 2,33 a A & 2,36 b A & 2,06 a A & $2,24 \mathrm{~b}$ \\
SAF 2 & $1,72 \mathrm{~b} \mathrm{~B}$ & 1,89 a AB & 2,74 ab A & 2,13 a AB & $2,12 \mathrm{~b}$ \\
Monocultivo & 3,26 a A & 1,83 a B & 3,20 a A & 2,65 a AB & 2,74 a \\
Médias & $2,41 \mathrm{AB}$ & $2,02 \mathrm{~B}$ & $2,77 \mathrm{~A}$ & $1,95 \mathrm{AB}$ & \\
C.V. (\%) & 10,16 & & & & \\
C.V. $(\%)$ & 19,99 & & & & \\
\hline
\end{tabular}

- Médias seguidas de letras minúsculas iguais na vertical não diferem entre si pelo teste de Tukey a $5 \%$ de probabilidade.

- Médias seguidas de letras maiúsculas iguais na horizontal não diferem entre si pelo teste de Tukey a $5 \%$ de probabilidade.

O fato do monocultivo ter apresentado valor mais alto de IAF, é devido, provavelmente, ao maior adensamento das plantas, que proporcionou uma produção maior de perfilhos e de folhas por área.

Ao analisarem-se as épocas de avaliação para cada sistema, constatou-se que tanto no SAF 1 como no SAF 2, o valor máximo do IAF ocorreu na terceira avaliação com 2,36 e 2,74 $\mathrm{m}^{2}$ de folha/ $\mathrm{m}^{2}$ de área de solo, respectivamente. No SAF 1, estudando-se as quatro épocas não detectou-se diferença entre elas. O SAF 2 apresentou um IAF maior na terceira época em relação a primeira, porém os valores de ambos não diferenciaram daqueles da segunda e quarta épocas de avaliação. 
No monocultivo, verificou-se que o IAF apresentou um maior valor $(3,26)$ na primeira avaliação, realizada em março/99, porém semelhante estatisticamente ao IAF da terceira e da quarta avaliações, enquanto a segunda medição se apresentou significativamente menor $(1,83)$.

Estudando a radiação solar em meio vegetal para estimar o IAF, Wandelli \& Marques Filho (1999) observaram que em um SAF com palmeiras o IAF médio foi de 2,04, valor aproximado ao encontrado no presente estudo. Estes autores, comparando um SAF com palmeiras com um SAF multiestratificado sem a presença de palmeiras, constataram que o incremento médio anual de IAF foi de 0,51 e 0,39 para o SAF com e sem palmeiras, respectivamente.

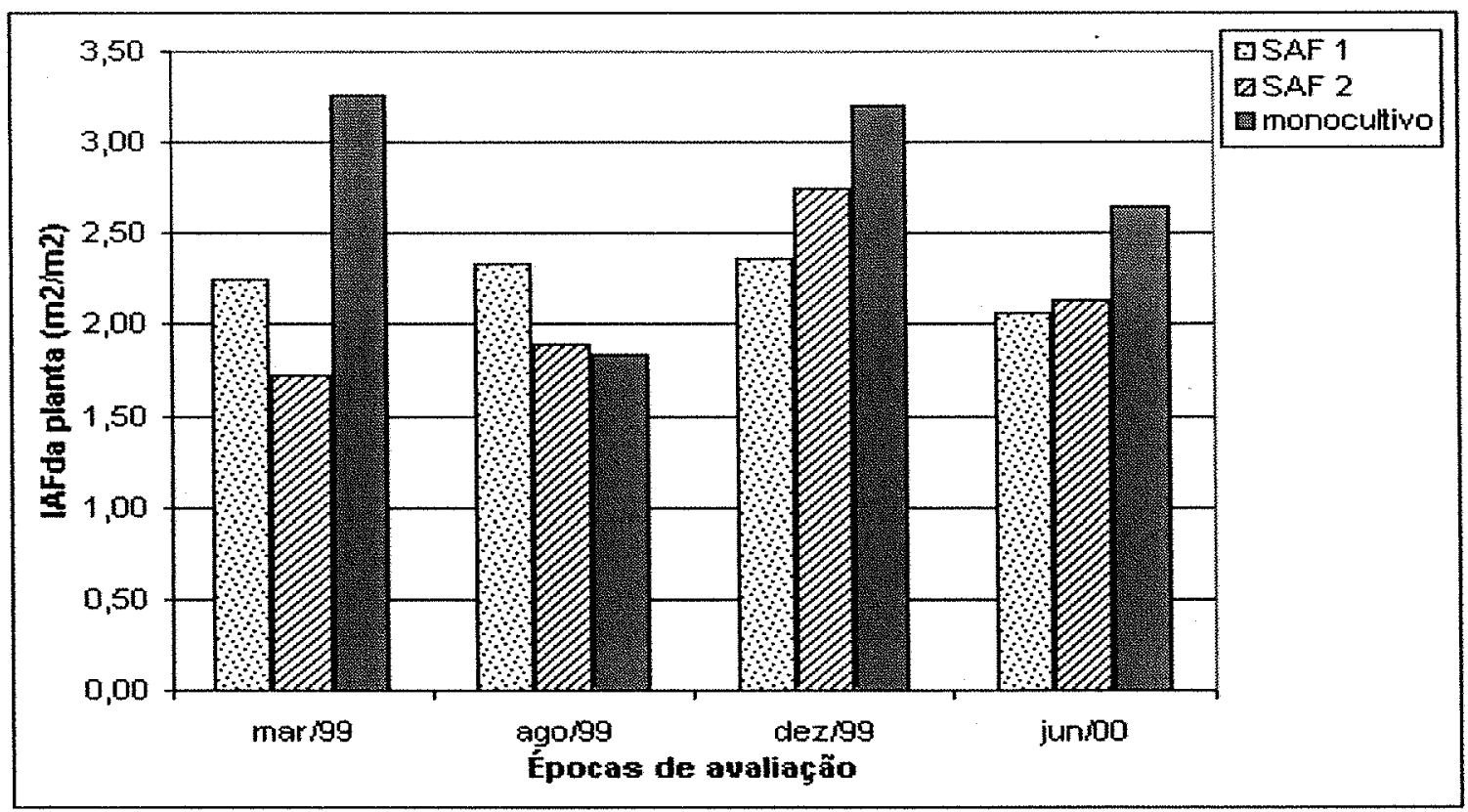

Figura 15 - Índice de área foliar (IAF $-\mathrm{m}^{2}$ de folha $/ \mathrm{m}^{2}$ de área de solo ocupada) da planta para os três sistemas estudados para cada época de avaliação. 


\subsubsection{Diâmetro da copa}

A Tabela 7 e a Figura 16 apresentam as médias entre sistemas para a variável diâmetro da copa.

No monocultivo, a observação de sobreposição de copas mostrou que o seu diâmetro médio foi de aproximadamente $2,30 \mathrm{~m}$, menor, portanto que a dos SAFs, que variaram entre $2,72 \mathrm{~m}$ e 3,45 m. O diâmetro da copa das pupunheiras não foi diferente entre os SAFs em todas as épocas. Por outro lado, houve variação de diâmetro de copa entre as épocas de avaliação. O diâmetro da copa registrado na terceira época (dezembro/99), foi significativamente inferior ao da quarta época (junho/00). Esse menor crescimento das copas pode ser explicado pela menor disponibilidade de água para as plantas no período que antecedeu a terceira avaliação, conforme mostra a Figura 3. Durante a terceira avaliação, mesmo registrando-se uma aceleração no desenvolvimento vegetativo, as folhas ainda encontravam-se jovens o que explica nesta mesma época o diâmetro da copa ser significativamente inferior. O diâmetro médio maior, registrado na quarta época, indica que com o início das chuvas, houve uma retomada do crescimento.

Tabela 7. Diâmetros médios da copa $(\mathrm{m})$ por planta comparado entre os dois sistemas agroflorestais e entre as épocas de avaliação.

\begin{tabular}{cccccc}
\hline Tratamentos & \multicolumn{5}{c}{ Épocas } \\
\cline { 2 - 6 } & mar/99 & Ago/99 & dez/99 & jun/00 & médias \\
\hline SAF 1 & 3,08 a AB & 3,25 a $\mathrm{AB}$ & 2,90 a B & $3,45 \mathrm{a} \mathrm{A}$ & $3,17 \mathrm{a}$ \\
SAF 2 & $2,99 \mathrm{a} \mathrm{AB}$ & $3,23 \mathrm{aAB}$ & $2,72 \mathrm{a} \mathrm{B}$ & $3,18 \mathrm{a} \mathrm{A}$ & $3,03 \mathrm{a}$ \\
Médias & $3,04 \mathrm{AB}$ & $3,24 \mathrm{AB}$ & $2,81 \mathrm{~B}$ & $3,22 \mathrm{~A}$ & \\
C.V. $(\%)$ & 6,92 & & & & \\
C.V. $(\%)$ & 13,48 & & & & \\
\hline
\end{tabular}

- Médias seguidas de letras minúsculas iguais na vertical não diferem entre si pelo teste de Tukey a $5 \%$ de probabilidade.

- Médias seguidas de letras maiúsculas iguais na horizontal não diferem entre si pelo teste de Tukey a $5 \%$ de probabilidade. 


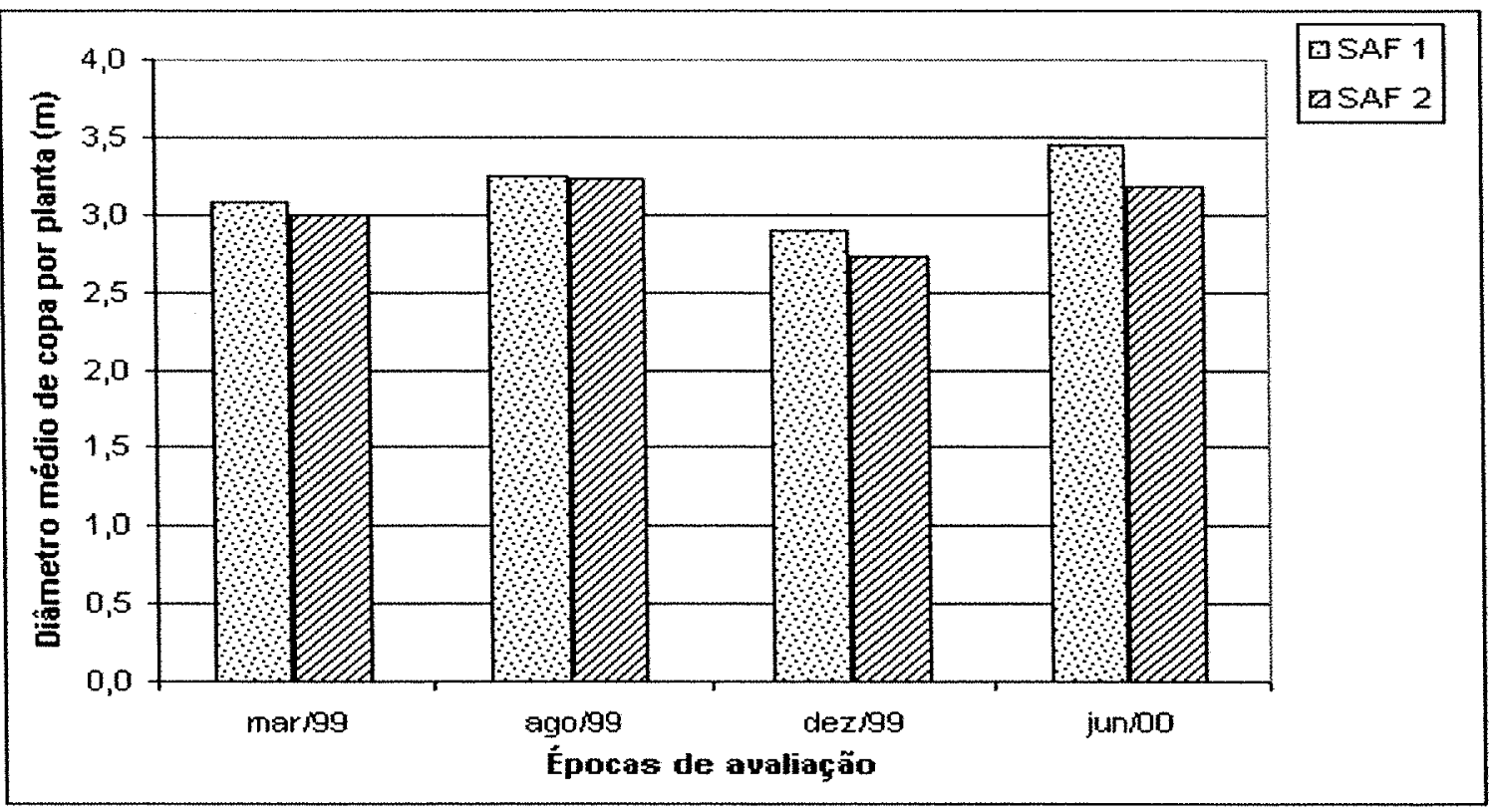

Figura 16 - Diâmetro médio da copa da planta $(\mathrm{m})$ para os dois sistemas agroflorestais em cada época de avaliação.

\subsubsection{Altura da planta}

A altura média das plantas nos dois SAFs, na primeira e na segunda épocas de avaliação apresentaram-se iguais estatisticamente, enquanto o da segunda avaliação se apresentou igual a terceira, que por sua vez não se diferenciou estatisticamente da quarta época avaliação (Tabela 8 e Figura 17).

Esta variável, segundo Bovi et al. (1988) e Clement (1995) apresenta correlação positiva e significativa com a produção de palmito. Plantas maiores, geralmente possuem massa de palmito maior devido ao maior diâmetro em relação às plantas mais jovens (Gomes \& Arkcoll, 1988). Este estudo concorda parcialmente com estes autores. $\mathrm{Na}$ terceira época constatou-se pouca altura das plantas e menor massa de palmitos. Entretanto, na quarta avaliação registrou-se uma menor altura das plantas e uma produção de palmitos superior. Isto parece ter ocorrido pelo maior número de perfilhos colhidos 
apesar da pouca altura das plantas. Por outro lado, na primeira avaliação, os resultados deste estudo concordam inteiramente com os autores citados.

Tabela 8. Altura média das plantas $(\mathrm{m})$ comparada entre os dois sistemas agroflorestais e entre as épocas de avaliação.

\begin{tabular}{cccccc}
\hline Tratamentos & \multicolumn{5}{c}{ Épocas } \\
\cline { 2 - 6 } & mar/99 & ago/99 & dez/99 & jun/00 & médias \\
\hline SAF 1 & 3,68 a A & 3,61 a AB & 2,85 a BC & 2,73 a C & 3,22 a \\
SAF 2 & 4,09 a A & 3,56 a AB & 2,87 a BC & 2,65 a C & 3,29 a \\
Médias & 3,88 A & 3,58 AB & $2,86 \mathrm{BC}$ & $2,69 \mathrm{C}$ & \\
C.V. (\%) & 10,47 & & & & \\
C.V. (\%) & 16,77 & & & & \\
\hline
\end{tabular}

- Médias seguidas de letras minúsculas iguais na vertical não diferem entre si pelo teste de Tukey a $5 \%$ de probabilidade.

- Médias seguidas de letras maiúsculas iguais na horizontal não diferem entre si pelo teste de Tukey a $5 \%$ de probabilidade.

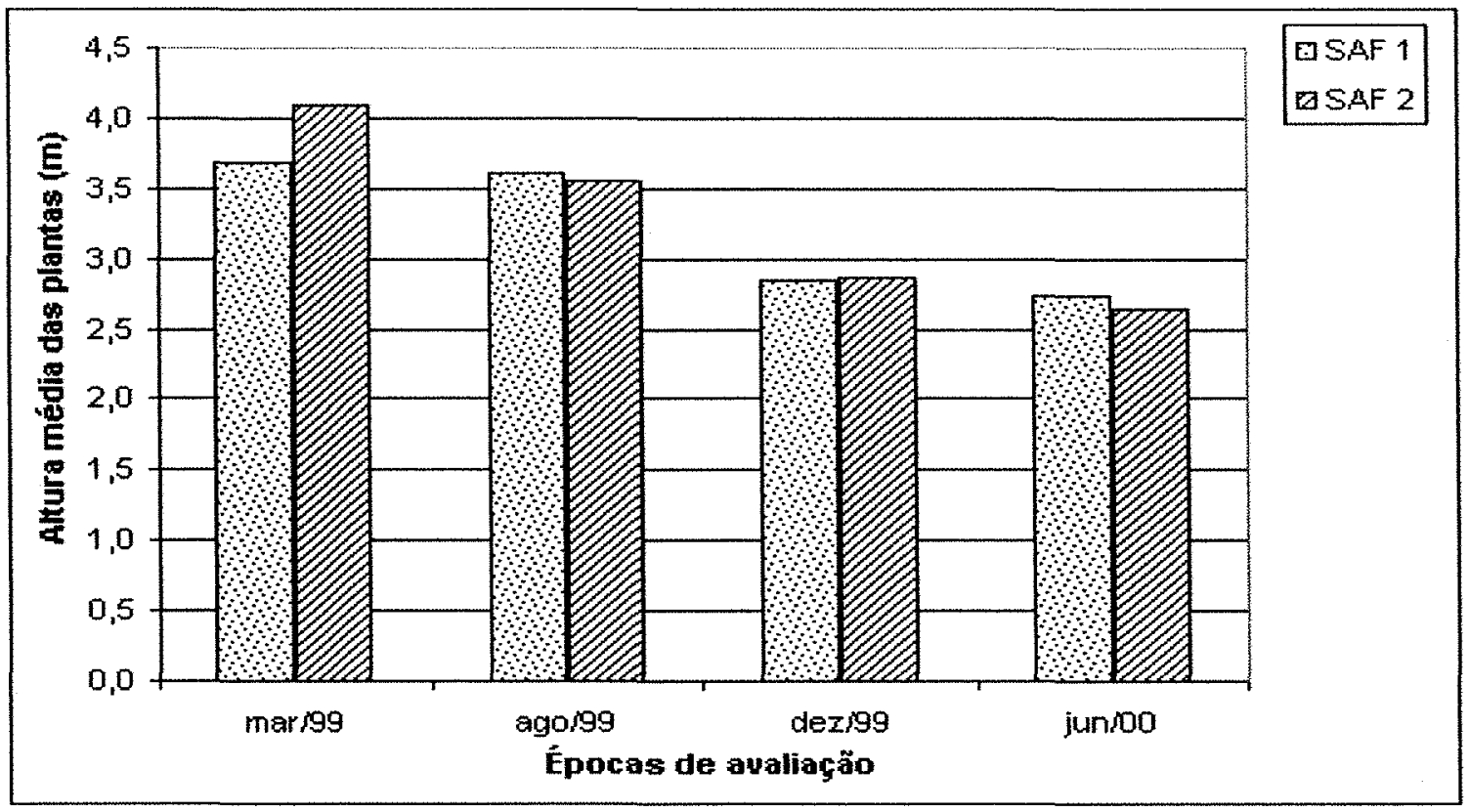

Figura 17 - Altura média da planta $(\mathrm{m})$ para os dois sistemas agroflorestais em cada época de avaliação. 


\subsection{Produção das pupunheiras}

\subsubsection{Número de palmitos colhidos por planta}

Verifica-se na Tabela 9 que o número médio de palmitos colhidos por planta foi igual estatisticamente nos três sistemas de cultivo em todas as épocas de avaliação. Porém, na terceira época, o número de palmitos colhidos foi significativamente menor em todos os sistemas ao comparar-se a produção entre as épocas (Figura 18). Segundo Bovi (1998), a produção é muito influenciada por deficiência hídrica, justificando os resultados da terceira avaliação, em que houve uma menor colheita do produto, e obviamente, uma menor produção total e da quarta avaliação, que com aumento da precipitação pluviométrica, o meristema voltou a crescer, implicando em uma maior produção. A importante o conhecimento sobre o número de palmitos colhidos para se estimar a produção, podendo ser usado rotineiramente, especialmente quando a produção for destinada a indústria (Clement \& Bovi, 2000).

Tabela 9. Número médio de palmitos colhidos por planta comparada entre os sistemas de cultivo e entre as épocas de avaliação.

\begin{tabular}{cccccc}
\hline Tratamentos & \multicolumn{5}{c}{ Épocas } \\
\cline { 2 - 6 } & mar/99 & ago/99 & dez/99 & jun/00 & Médias \\
\hline SAF 1 & 0,765 a A & 0,602 a A & 0,102 a B & 0,710 a A & 0,545 a \\
SAF 2 & 0,514 a A & 0,489 a A & 0,178 a B & 0,522 a A & 0,426 a \\
Monocultivo & 0,975 a A & 0,540 a A & 0,334 a B & 0,563 a A & 0,603 a \\
Médias & 0,570 A & 0,540 A & $0,200 \mathrm{~B}$ & $0,600 \mathrm{~A}$ & \\
C.V. (\%) & 5,82 & & & & \\
C.V. (\%) & 12,66 & & & & \\
\hline
\end{tabular}

- Médias seguidas de letras minúsculas iguais na vertical não diferem entre si pelo teste de Tukey a $5 \%$ de probabilidade.

- Médias seguidas de letras maiúsculas iguais na horizontal não diferem entre si pelo teste de Tukey a $5 \%$ de probabilidade. 


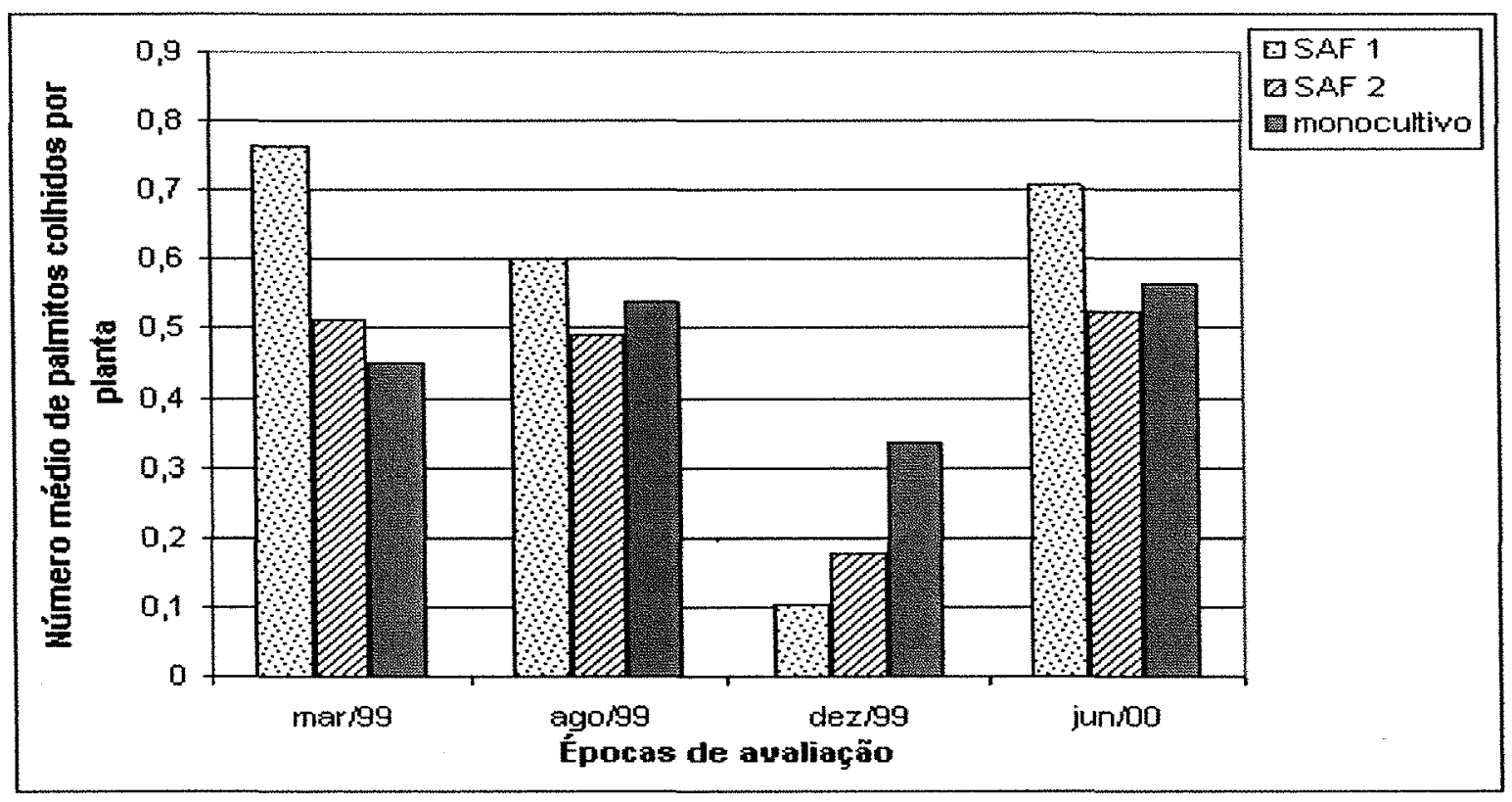

Figura 18 - Número médio de palmitos colhidos por planta nos três sistemas de cultivo em cada época de avaliação.

\subsubsection{Diâmetro e comprimento do palmito por planta}

Para diâmetro e comprimento médio do palmito das pupunheiras, não foi verificado diferença estatística entre os sistemas de cultivo e entre as épocas de avaliação, mas notou-se que na terceira época de avaliação, em dezembro/99, os palmitos apresentaram um diâmetro médio de $1,8 \mathrm{~cm}$, ou seja, bem inferior ao ideal para a comercialização, que é em torno de 2,0 a $2,5 \mathrm{~cm}$ (Tabela 10). Também nesta mesma época, o comprimento dos palmitos foi aproximadamente $22 \%$ menor que o comprimento médio das demais épocas de avaliação (Tabela 11). O número de folhas está intimamente associado ao diâmetro médio e ao comprimento do palmito, assim como a altura da planta mostra uma associação fenotípica com o diâmetro (Bovi et al. 1992). Resultados semelhantes foram encontrados neste estudo, onde observou-se que a quarta avaliação apresentou um maior número de folhas, o que refletiu em comprimento e diâmetro do palmito satisfatórios para a exigência da 
indústria. Uma vez que diâmetro e comprimento são componentes do peso, conseqüentemente, a produção total de palmitos nessa época foi superior a anterior. Na terceira avaliação, embora tenha ocorrido um grande perfilhamento e emissão foliar, as plantas ainda estavam no estágio de acumular reservas e, portanto, obteve-se uma menor produção, o que demonstra uma relação nem sempre obrigatória dessas características com a produção.

Tabela 10. Diâmetro médio do palmito por planta $(\mathrm{cm})$ comparado entre os sistemas de cultivo e entre as épocas de avaliação.

\begin{tabular}{cccccc}
\hline Tratamentos & \multicolumn{5}{c}{ Épocas } \\
\cline { 2 - 6 } & mar/99 & ago/99 & dez/99 & jun/00 & Médias \\
\hline SAF 1 & 2,7 a A & 1,3 a A & 1,5 a A & 3,0 a A & 2,1 a \\
SAF 2 & 2,4 a A & 2,3 a A & 1,6 a A & 2,3 a A & 2,2 a \\
Monocultivo & 2,6 a A & 2,3 a A & 2,5 a A & 2,5 a A & 2,5 a \\
Médias & 2,6 A & 2,0 A & 1,8 A & 2,6 A & \\
C.V. $(\%)$ & 10,42 & & & & \\
C.V. $(\%)$ & 14,88 & & & & \\
\hline
\end{tabular}

- Médias seguidas de letras minúsculas iguais na vertical não diferem entre si pelo teste de Tukey a $5 \%$ de probabilidade.

- Médias seguidas de letras maiúsculas iguais na horizontal não diferem entre si pelo teste de Tukey a $5 \%$ de probabilidade.

Tabela 11. Comprimento médio do palmito por planta $(\mathrm{cm})$ comparado entre os sistemas de cultivo e entre as épocas de avaliação.

\begin{tabular}{cccccc}
\hline Tratamentos & \multicolumn{5}{c}{ Épocas } \\
\cline { 2 - 6 } & mar/99 & ago/99 & dez/99 & jun/00 & Médias \\
\hline SAF 1 & 34,5 a A & 31,6 a A & 24,8 a A & 35,5 a A & 31,6 a \\
SAF 2 & 30,4 a A & 27,8 a A & 21,5 a A & 33,1 a A & 28,2 a \\
Monocultivo & 39,6 a A & 32,3 a A & 30,5 a A & 30,3 a A & 33,2 a \\
Médias & 34,8 A & 30,6 A & 25,6 A & 33,0 A & \\
C.V. (\%) & 13,27 & & & & \\
C.V. (\%) & 20,93 & & & & \\
\hline
\end{tabular}

- Médias seguidas de letras minúsculas iguais na vertical não diferem entre si pelo teste de Tukey a $5 \%$ de probabilidade.

- Médias seguidas de letras maiúsculas iguais na horizontal não diferem entre si pelo teste de Tukey a $5 \%$ de probabilidade. 


\subsubsection{Produção de palmito creme por planta}

$\mathrm{Na}$ Tabela 12, pode-se observar que para a variável massa do palmito creme também não houve diferença estatística entre os sistemas. Entretanto, entre as épocas de avaliação, na terceira época a produção de palmito creme foi significativamente menor, enquanto que na primeira época esta foi estatisticamente superior à terceira e igual às outras duas colheitas (Figura 19). Tal resultado era esperado devido a pequena quantidade de palmitos colhidos em conseqüência das condições climáticas que antecederam esta avaliação, como já comentado no itens anterior.

Tabela 12. Médias da massa do palmito creme por planta $(\mathrm{g})$ comparadas entre os sistemas de cultivo entre as épocas de avaliação.

\begin{tabular}{|c|c|c|c|c|c|c|}
\hline \multirow[t]{2}{*}{ Tratamentos } & \multicolumn{4}{|c|}{ Épocas } & \multirow[b]{2}{*}{ médias } & \multirow[b]{2}{*}{ TOTAL } \\
\hline & $\mathrm{mar} / 99$ & ago/99 & dez/99 & jun/00 & & \\
\hline SAF 1 & 231,1 a A & $130,2 \mathrm{a} A \mathrm{~B}$ & 92,3 a $B$ & $183,2 \mathrm{a} A \mathrm{~B}$ & $159,2 a$ & 636,8 \\
\hline SAF 2 & 154,2 a $A$ & $117,8 \mathrm{a} A B$ & 97,2 a $B$ & $162,8 \mathrm{a} A B$ & $133,0 \mathrm{a}$ & 532,0 \\
\hline Monocultivo & 229,4 a $A$ & $177,8 \mathrm{a} A \mathrm{~B}$ & 172,3 aB & $162,2 \mathrm{a} A \mathrm{~B}$ & 185,4 a & 741,7 \\
\hline Médias & $204,9 \mathrm{~A}$ & $141,9 \mathrm{AB}$ & $120,6 \mathrm{~B}$ & $169,4 \mathrm{AB}$ & & \\
\hline C.V. $(\%)$ & 17,28 & & & & & \\
\hline C.V. (\%) & 23,77 & & & & & \\
\hline
\end{tabular}

- Médias seguidas de letras minúsculas iguais na vertical não diferem entre si pelo teste de Tukey a $5 \%$ de probabilidade.

- Médias seguidas de letras maiúsculas iguais na horizontal não diferem entre si pelo teste de Tukey a $5 \%$ de probabilidade. 


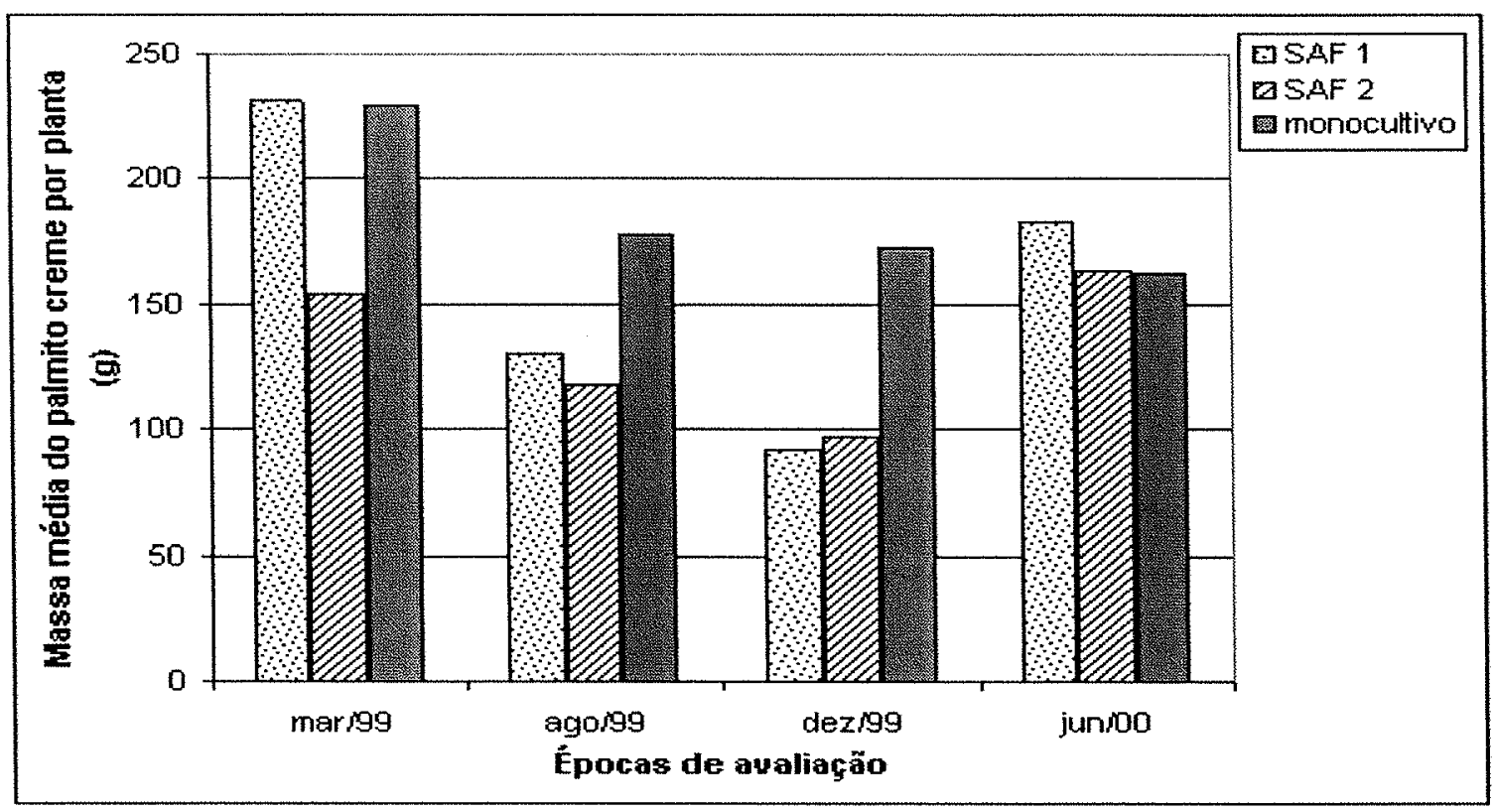

Figura 19 - Massa média do palmito creme por planta (g) para os três sistemas de cultivo em cada época de avaliação.

\subsubsection{Produção de resíduos industriais de palmito por planta}

Para a massa de resíduo industrial de palmito, observou-se que durante a segunda e a quarta avaliações, houve uma grande quantidade desses resíduos. Nestas épocas, a quantidade de resíduos foi estatisticamente iguais entre si e nas outras duas épocas de avaliação as produções foram também significativamente iguais, porém, inferiores. Os sistemas de cultivo apresentaram-se iguais estatisticamente entre si (Tabela 13 e Figura 20). 
Tabela 13. Massa média de resíduo industrial de palmito por planta ( $g$ ) comparada entre os sistemas de cultivo e entre as épocas de avaliação.

\begin{tabular}{cccccc}
\hline Tratamentos & \multicolumn{5}{c}{ Épocas } \\
\cline { 2 - 6 } & mar/99 & ago/99 & dez/99 & jun/00 & médias \\
\hline SAF 1 & 31,0 a B & 52,3 a A & 24,2 a B & 78,2 a A & 46,4 a \\
SAF 2 & 17,4 a B & 48,3 a A & 22,3 a B & 64,9 a A & 38,2 a \\
Monocultivo & 19,6 a B & 49,9 a A & 37,9 a B & 68,9 a A & 44,1 a \\
Médias & 22,7 B & 50,2 A & 28,1 B & 70,7 A & \\
C.V. (\%) & 15,93 & & & & \\
C.V. (\%) & 20,68 & & & & \\
\hline
\end{tabular}

- Médias seguidas de letras minúsculas iguais na vertical não diferem entre si pelo teste de Tukey a $5 \%$ de probabilidade.

- Médias seguidas de letras maiúsculas iguais na horizontal não diferem entre si pelo teste de Tukey a $5 \%$ de probabilidade.

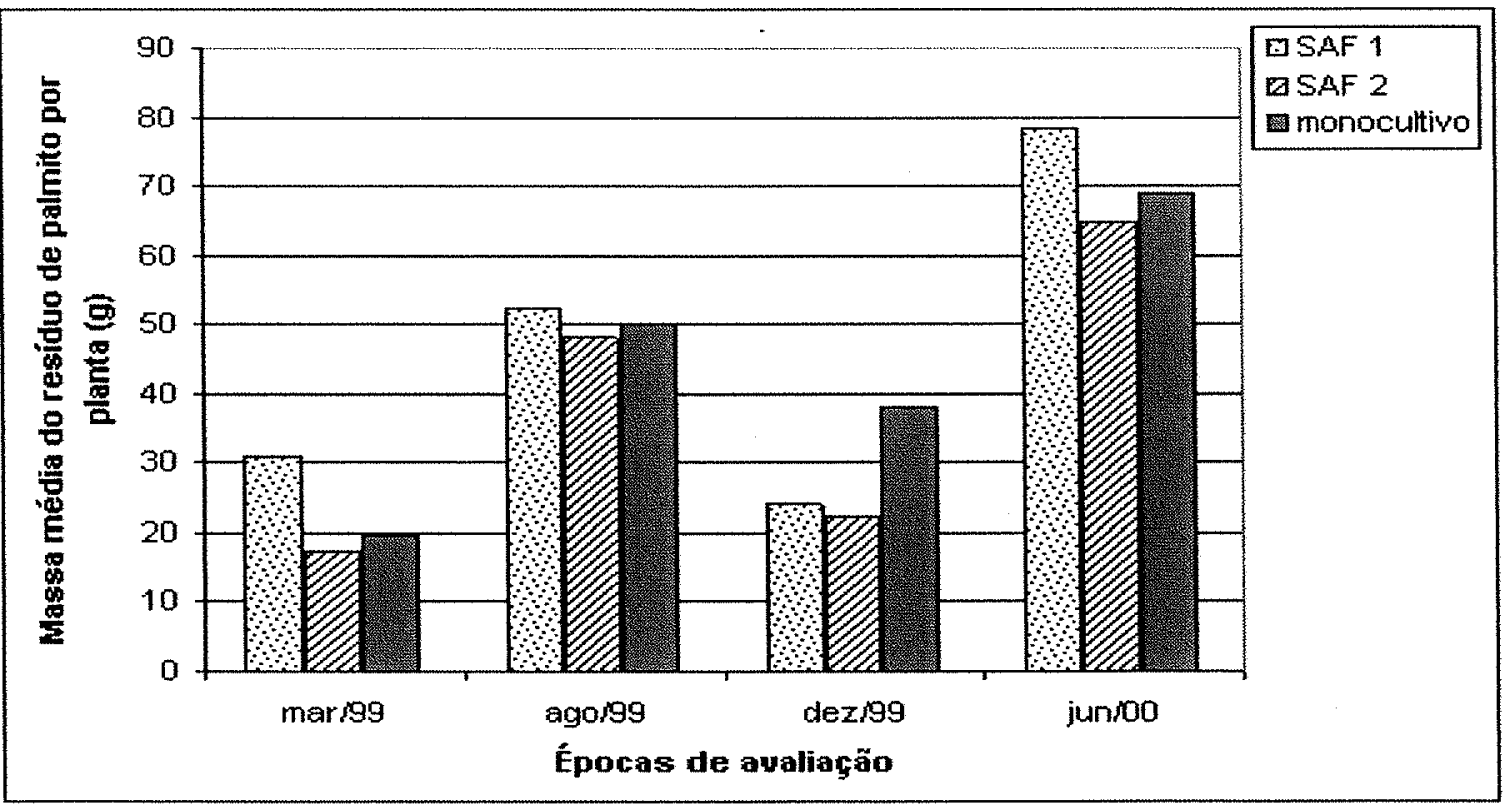

Figura 20 - Massa média dos resíduos industriais de palmitos por planta (g) para os três sistemas de cultivo em cada época de avaliação. 


\subsubsection{Produção total de palmito por planta}

A produção total de palmitos por planta da segunda e terceira épocas de avaliação, agosto/99 e dezembro/99 respectivamente, foram estatisticamente iguais entre si e inferiores as outras duas épocas. Entretanto, em valores absolutos, a terceira época apresentou uma produção sensivelmente inferior a segunda. A baixa produção nessas duas épocas de avaliação, possivelmente foi devido ao período de baixa temperatura do ar (Figura 2) e da baixa precipitação pluviométrica, ocorrida nos períodos prévios a cada uma dessas duas colheitas (Figura 3). Na terceira época, observou-se que muitas plantas não produziram estipes que atingissem diâmetro mínimo para o corte, chegando a não haver produção em parcelas inteiras como ocorreu no bloco A do SAF 2 e no bloco $C$ do SAF 1. Tal fato comprova que a baixa precipitação limita o crescimento e a produção das pupunheiras. Segundo Villachica (1996a), tanto a precipitação pluviométrica total quanto a sua distribuição no tempo são importantes, pois a planta não tolera períodos secos maiores que três meses, o que ocasiona redução do crescimento e da frutificação.

Essa menor produção obtida na terceira avaliação pode ser atribuída, em parte, ao menor intervalo de tempo entre os cortes realizados entre a segunda e a terceira épocas de avaliação (Tabela 14).

Schroth et al (2001), trabalhando na mesma área experimental deste estudo, obtiveram uma produção de palmito de 400 a $850 \mathrm{~g}$ por planta e Clement (1988) em experimentos com monocultivos na Amazônia Central, obteve em torno de $500 \mathrm{~g}$ por planta em uma área de 2500 plantas por ha. Estes resultados assemelham-se aos encontrados neste estudo, embora neste, a produção do monocultivo tenha sido inferior ao relatado por estes autores. $A$ análise mostrou diferença estatística entre as épocas de avaliação, apenas quando realizaram-se os contrastes entre as médias a $10 \%$ de probabilidade. 
Tabela 14. Massa total média de palmitos por planta $(\mathrm{g})$ comparada entre os sistemas de cultivo e entre as épocas de avaliação.

\begin{tabular}{ccccccc}
\hline Tratamentos & \multicolumn{7}{c}{ Épocas } \\
\cline { 2 - 7 } & mar/99 & ago/99 & dez/99 & jun/00 & médias & TOTAL \\
\hline SAF 1 & 261,8 a A & 183,8 a B & 116,2 a B & 264,5 a A & 206,6 a & 826,3 \\
SAF 2 & 171,7 a A & 169,3 a B & 118,8 a B & 200,8 a A & 165,2 a & 660,6 \\
Monocultivo 254,9 a A & 228,0 a B & 209,0 a B & 232,0 a A & 231,0 a & 923,9 \\
Médias & 229,5 A & 193,7 B & 148,0 B & 232,4 A & & \\
C.V. $(\%)$ & 16,74 & & & & & \\
C.V. $(\%)$ & 21,53 & & & & & \\
\hline
\end{tabular}

- Médias seguidas de letras iguais minúsculas na vertical não diferem entre si pelo teste de Tukey a $10 \%$ de probabilidade.

- Médias seguidas de letras iguais maiúsculas na horizontal não diferem entre si pelo teste de Tukey a $10 \%$ de probabilidade.

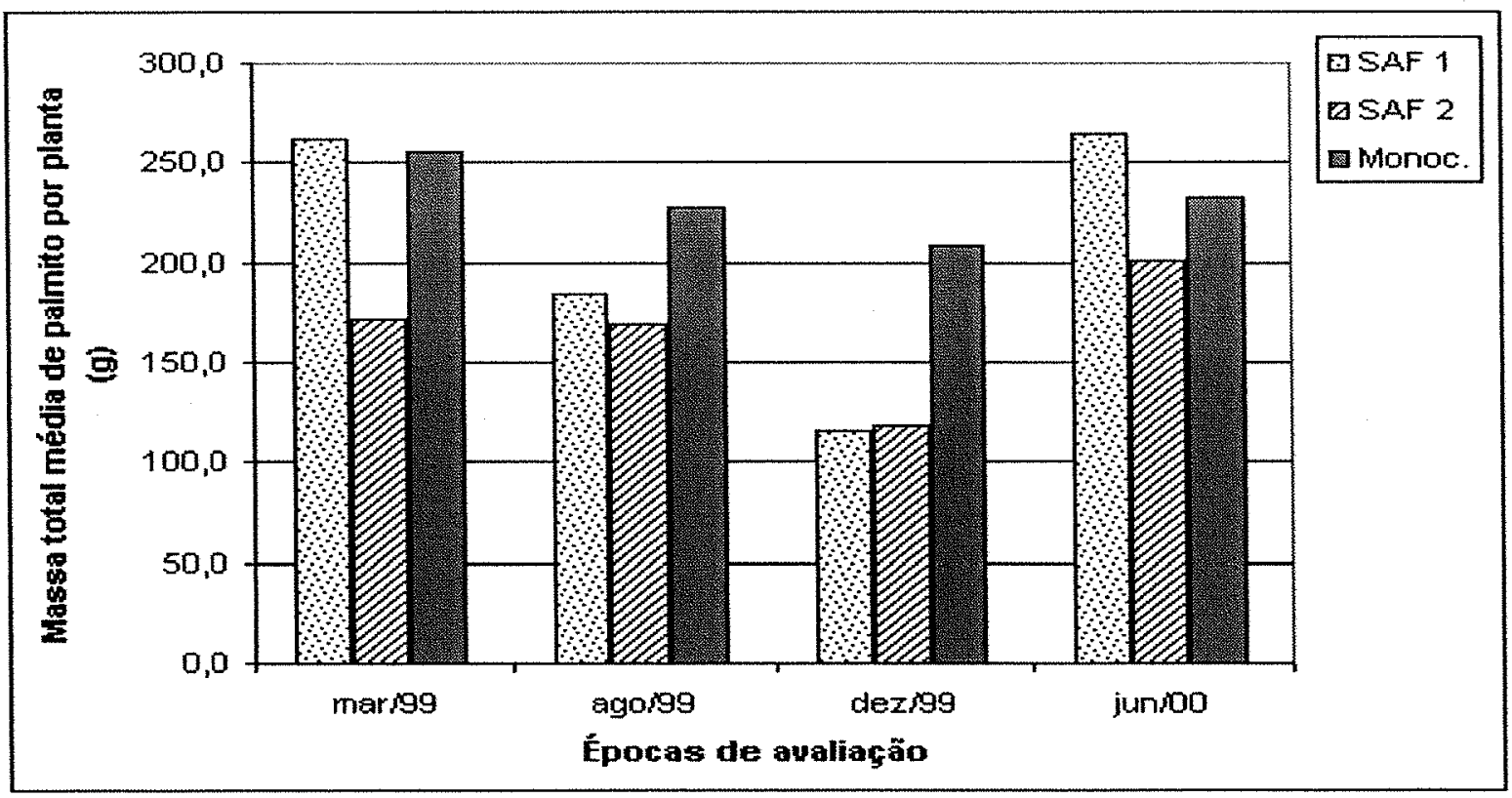

Figura 21 - Massa média do palmito total por planta $(\mathrm{g})$ para os três sistemas de cultivo em cada época de avaliação. 


\subsubsection{Produção total de palmito por hectare}

A pupunheira é, entre os componentes dos SAFs estudados, a planta perene que apresenta produção comercial mais precocemente. Conseqüentemente, a produção advinda dessas plantas indica a capacidade do sistema gerar receita até a entrada em produção das demais plantas perenes.

Neste aspecto, o SAF 2, devido ao menor número de pupunheiras por área, resultou em uma produção de palmitos por hectare muito pequena, enquanto que o monocultivo, foi o sistema que teve a produção mais elevada. Tal resultado era esperado, tendo visto haver uma quantidade de pupunheiras na área muito superior à dos demais sistemas. O SAF 1 foi constituído por um número de plantas de pupunha $50 \%$ maior que o SAF 2 e a sua produção foi superior $67,21 \%, 62,04 \%$ e $53,94 \%$ nas colheitas dos meses de março/99, maio/00 e agosto/99, a primeira, quarta e segunda colheita, respectivamente. A terceira, realizada em dezembro/99, foi a que menos produziu, apresentando uma produção $48 \%$ a mais que o SAF 2 (Tabela 15).

Assim, verifica-se que o SAF 1 foi sistematicamente superior, em termos de produção de palmito do que o SAF 2. Este desempenho coincide com os resultados preliminares da mesma área experimental apresentados por Macedo et al. (1998) onde o SAF 1 foi mais produtivo que o SAF 2. As pupunheiras no SAF 1 tiveram uma produção média de 115,130 e $95 \mathrm{~kg} / \mathrm{ha}$ aos 18,30 e 38 meses de idade, respectivamente. 
Tabela 15. Massa total média de palmitos por hectare $(\mathrm{kg} / \mathrm{ha})$ comparada entre os sistemas de cultivo e entre as épocas de avaliação.

\begin{tabular}{ccccccc}
\hline Tratamentos & \multicolumn{7}{c}{ Épocas } \\
\cline { 2 - 7 } & mar/99 & ago/99 & dez/99 & jun/00 & médias & TOTAL \\
\hline SAF 1 & 54,5 & 38,3 & 24,2 & 55,1 & 43,0 & 172,2 \\
SAF 2 & 17,9 & 17,6 & 12,4 & 21,0 & 17,2 & 68,8 \\
Monocultivo & 637,2 & 570,1 & 522,6 & 580,0 & 577,5 & 2309,9 \\
Médias & 236,6 & 208,7 & 186,4 & 218,677 & & \\
\hline
\end{tabular}

\subsubsection{Relações entre o crescimento e a produção}

$\mathrm{Na}$ terceira época de avaliação, foi constatado um aumento no número de perfilhos e de folhas por planta e na área foliar (Tabelas 1, 2 e 5). A produção de palmito, seja massa de creme, de resíduos industriais e total (Tabelas 11, 12 e 13), seja em número de palmitos colhidos, assim como a massa seca de suas folhas e perfilhos foram inferiores nesta época (Tabelas 8 , 3 e 4). No período que antecedeu essa avaliação, ocorreu uma baixa precipitação e a baixa umidade relativa do ar (Figura 3 e 5) associadas com elevada evaporação (Figura 6). Por outro lado, houve brilho solar em abundância (Figura 4). Dessa forma, as evidências apontadas acima indicam que a falta de água inibiu o desenvolvimento meristemático, resultando em pequena quantidade de palmito. Entretanto, a maior disponibilidade de radiação propiciou uma aceleração na emissão foliar e no perfilhamento, resultando em maior área foliar. Provavelmente, a coincidência de maior área foliar em decorrência do período de maior irradiância, possibilitou um aumento na taxa e na atividade fotossintética total, resultando em acúmulo de fotoassimilados para um crescimento posterior das plantas, dependente de disponibilidade hídrica. Assim, com o aumento da precipitação pluviométrica após a terceira época de avaliação, houve uma retomada do crescimento, principalmente do meristema, resultando em maior produção de palmito na avaliação seguinte (junho/00). 
Pode-se inferir que não há uma coincidência permanente entre o crescimento meristemático e a sua externalização através da emissão foliar e de perfilhos. O crescimento meristemático é favorecido principalmente pela disponibilidade hídrica, desde que haja fotoassimilados suficientes para suportar tal crescimento, enquanto que a emissão de folhas é favorecida pela luz. Aparentemente, uma área foliar maior parece indicar uma menor quantidade de palmito na planta. Assim, seria mais aconselhável adiar a colheita dos palmitos, através do corte de plantas com grande área foliar para após o período seco, pois a produção de palmito deverá aumentar substancialmente depois de um período chuvoso.

Embora o SAF 1 tenha se apresentado como o sistema mais produtivo, pode-se verificar que o seu rendimento de palmito creme por planta assemelhou-se ao dos demais. Na primeira época de avaliação, este SAF apresentou um rendimento de massa de palmito creme em relação à massa de palmito total de $88,3 \%$, o SAF 2 de $90,1 \%$ e o monocultivo de $90 \%$. Na segunda época, o rendimento foi de $70,8 \%$, de $69,6 \%$ e de $78 \%$ no SAF 1 , SAF 2 e monocultivo, respectivamente. Na terceira época, os SAFs tiveram um desempenho semelhante ao da primeira, ou seja, o SAF 1 permaneceu com rendimento mais baixo $(79,4 \%)$, enquanto o SAF 2 e o monocultivo apresentaram-se com rendimentos bem próximos, de $81,8 \%$ e de $82,4 \%$, respectivamente. Na última avaliação, o SAF 1 também apresentou o menor rendimento $69,3 \%$, enquanto o SAF 2 atingiu $81,1 \%$ e o monocultivo $70 \%$.

\subsection{Crescimento e biometria das árvores vizinhas}

\subsubsection{Diâmetro da copa}

Pode-se observar pela Figura 22, que no SAF 1, as árvores tiveram um maior aumento de copa no período compreendido entre a primeira e a segunda época de avaliação. O diâmetro da copa das seringueiras e das pupunheiras para a produção de frutos apresentaram crescimento similar a partir da segunda 
avaliação, com um crescimento lento, possivelmente em função da baixa precipitação ocorrida no mês de julho.

No SAF 2, o crescimento da copa das árvores teve um comportamento semelhante desde o início até o final das avaliações. Exceção às plantas de urucum, que sofreram uma poda de produção entre a primeira e a segunda avaliações (Figura 23).

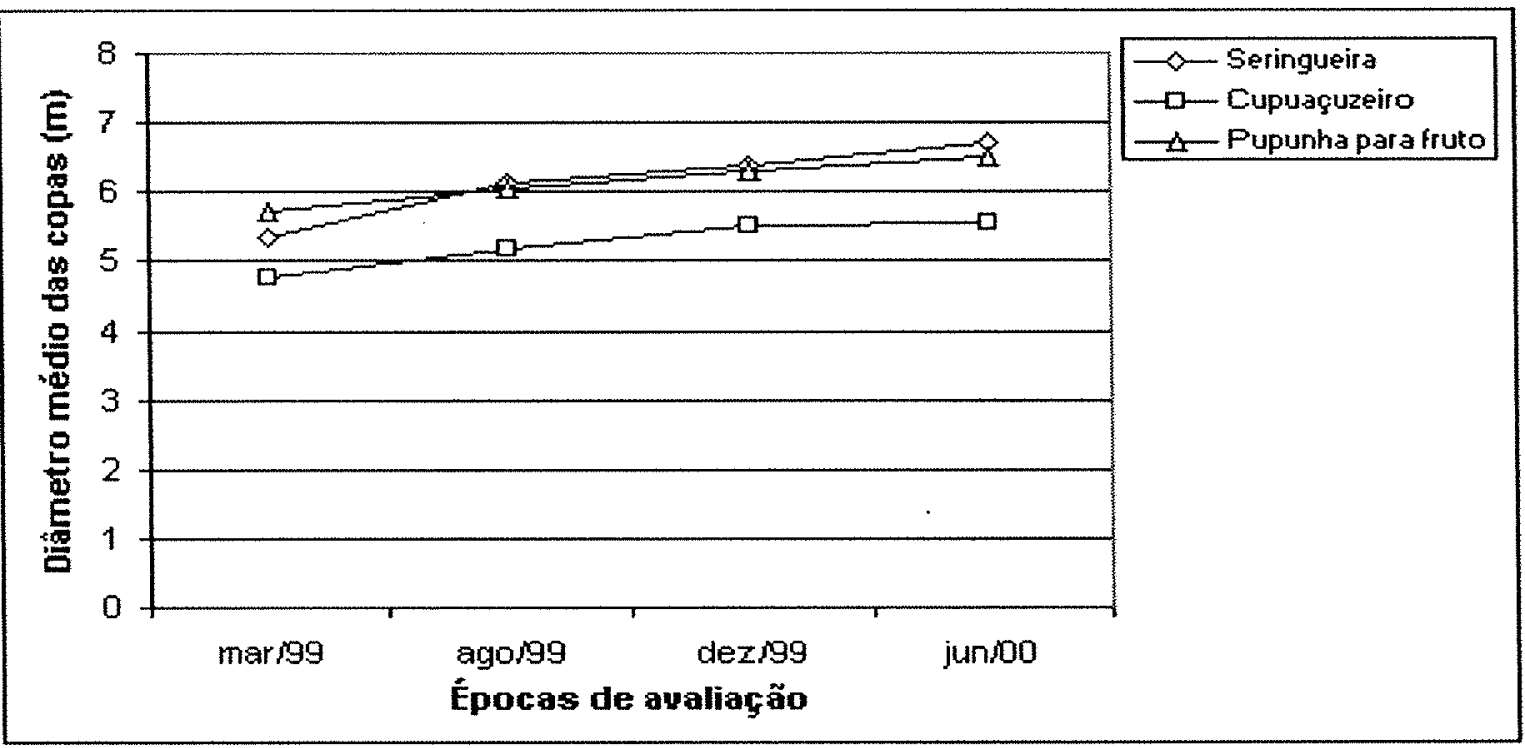

Figura 22 - Diâmetro médio da copa $(\mathrm{m})$ de seringueira, de cupuaçuzeiro e de pupunheira para a produção de frutos no SAF 1. 


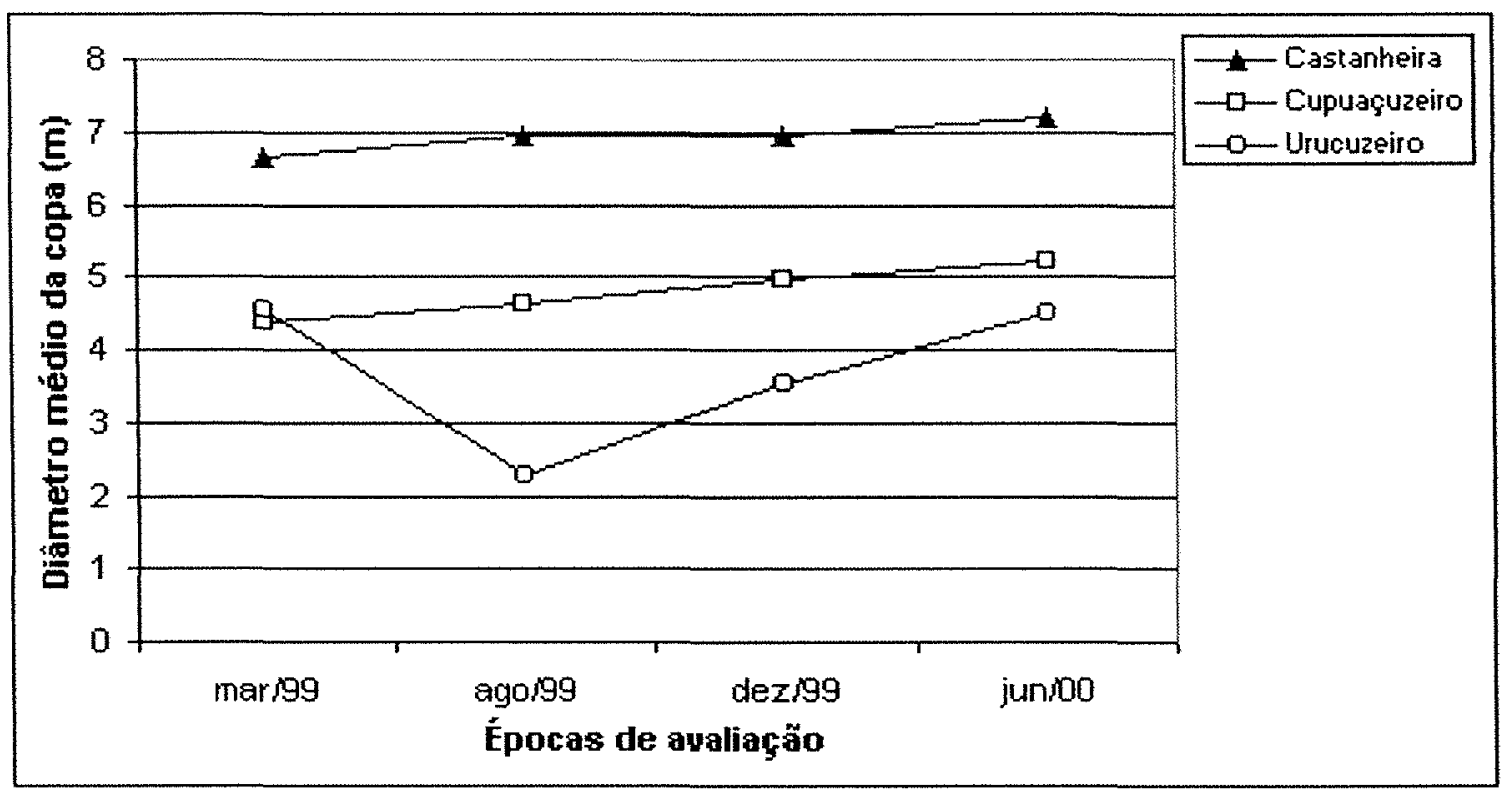

Figura 23 - Diâmetro médio da copa $(m)$ de castanheira-do-brasil, de cupuçuzeiro e de urucuzeiro no SAF 2.

\subsubsection{Altura das árvores}

Nas Figuras 24 e 25 são apresentados a altura das diferentes espécies vegetais que compõe os dois SAFs. No SAF 2, o urucuzeiro apresentou um decréscimo na altura devido a poda realizada entre a primeira e a segunda avaliações. As demais espécies no período experimental, apresentaram crescimento em altura inferior a $1 \mathrm{~m}$, com exceção da pupunheira para a produção de frutos, que apresentaram aumento em altura de aproximadamente $3 \mathrm{~m}$. 


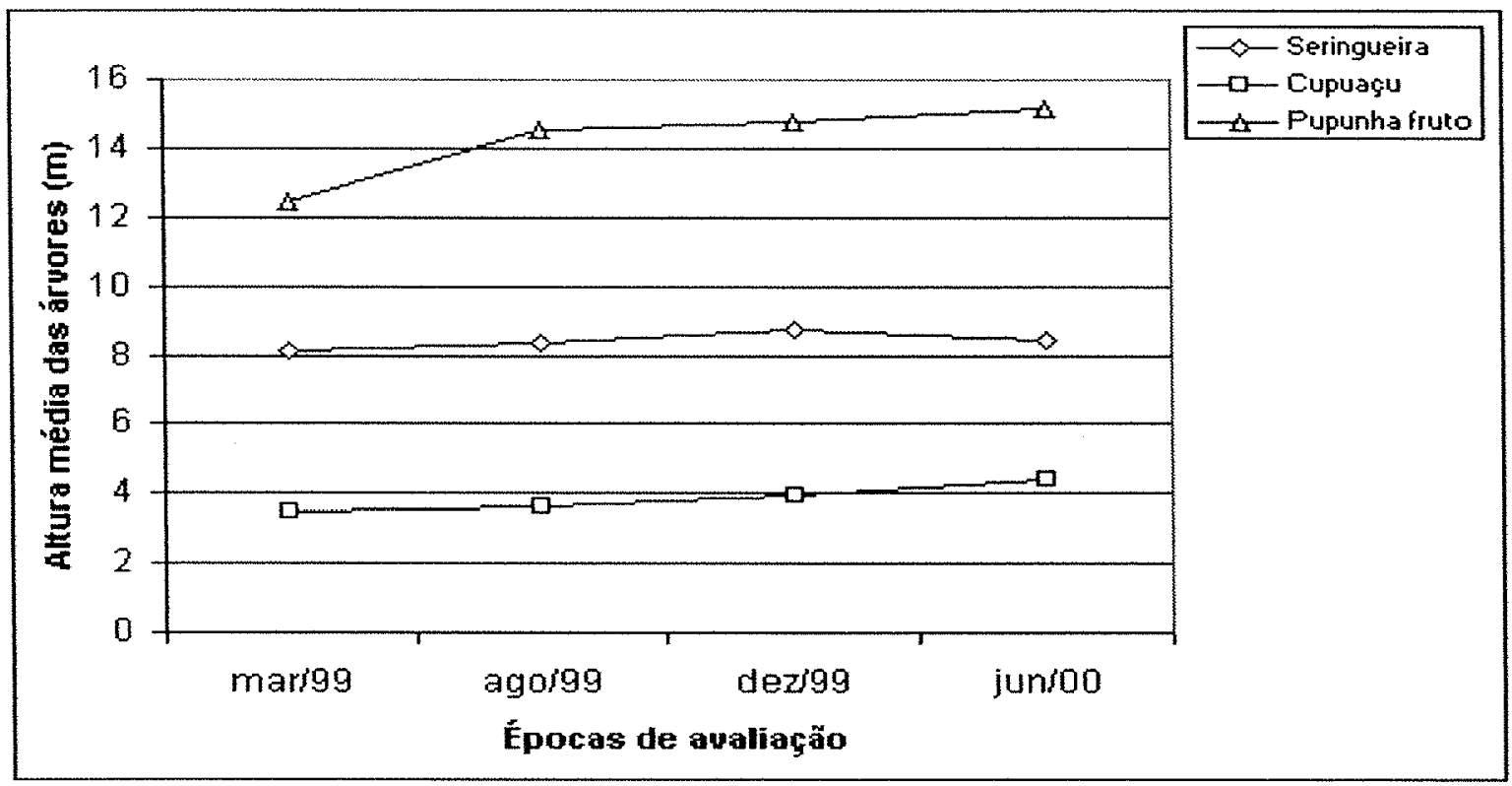

Figura 24 - Altura média $(m)$ de seringueira, de cupuaçuzeiro e de pupunheira para a produção de frutos no SAF 1.

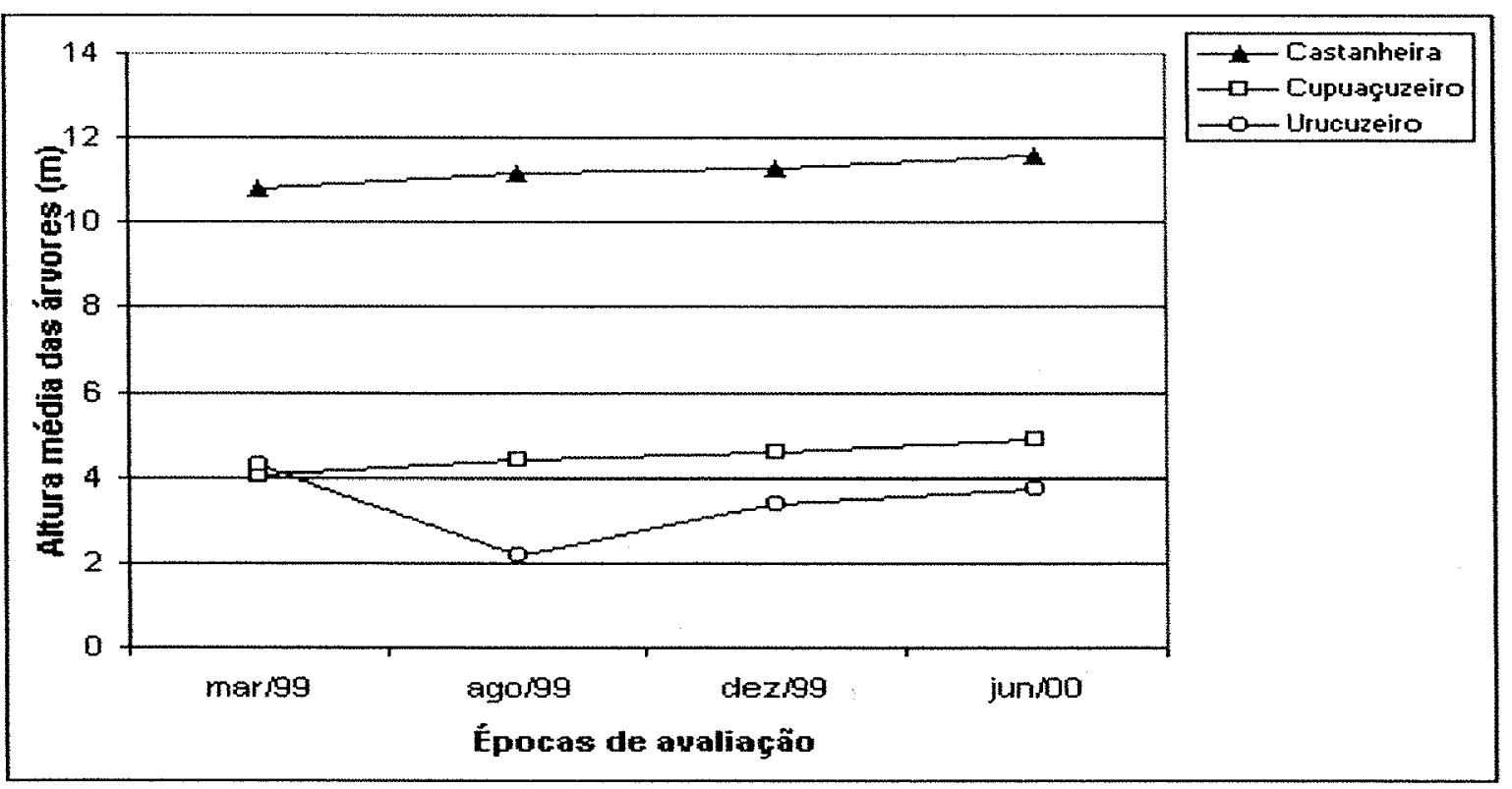

Figura 25 - Altura média $(\mathrm{m})$ de castanheira-do-brasil, de cupuaçuzeiro e de urucuzeiro no SAF 2. 


\subsubsection{Altura dos troncos}

Na Figura 26 e 27 estão apresentados os resultados das médias da altura do tronco das árvores vizinhas nos SAFs 1 e 2.

\subsubsection{Comprimento das copas}

O comprimento da copa das árvores vizinhas dos SAFs 1 e 2 podem ser visualizados nas Figuras 28 e 29.

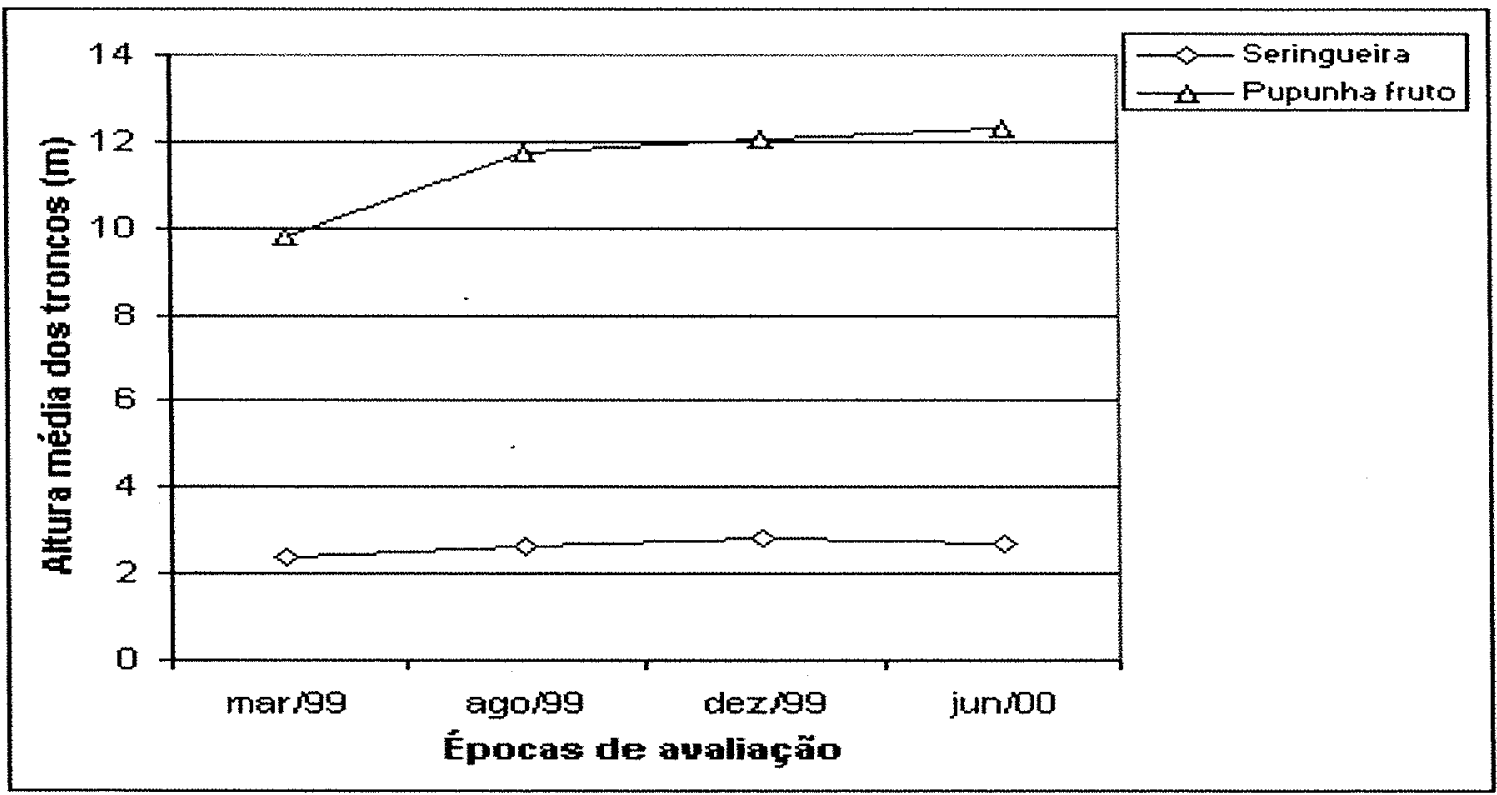

Figura 26 - Altura média dos troncos $(m)$ de seringueira e de pupunheira para a produção de frutos no SAF 1. 


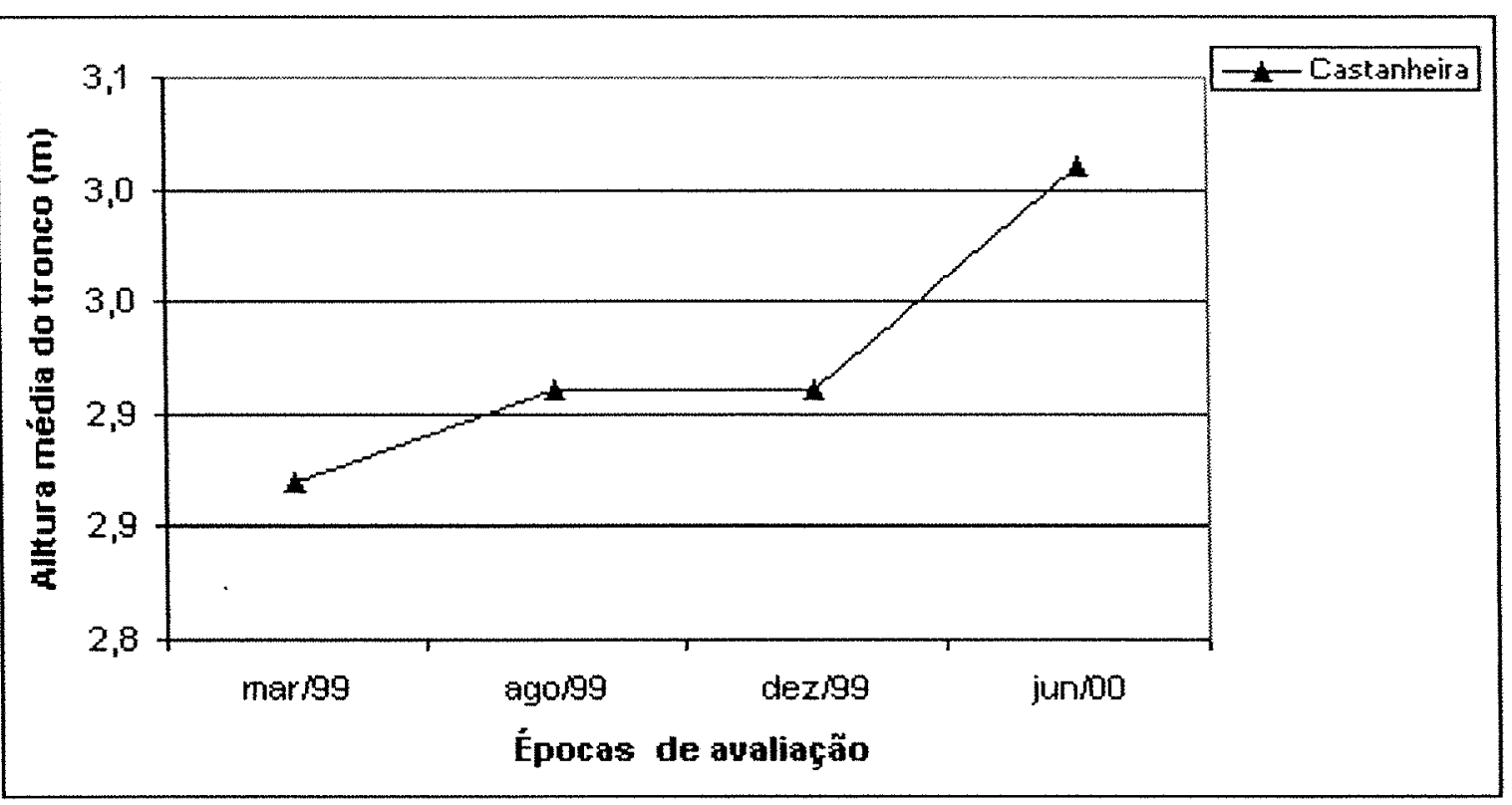

Figura 27 - Altura média do tronco $(\mathrm{m})$ de castanheira-do-brasil no SAF 2.

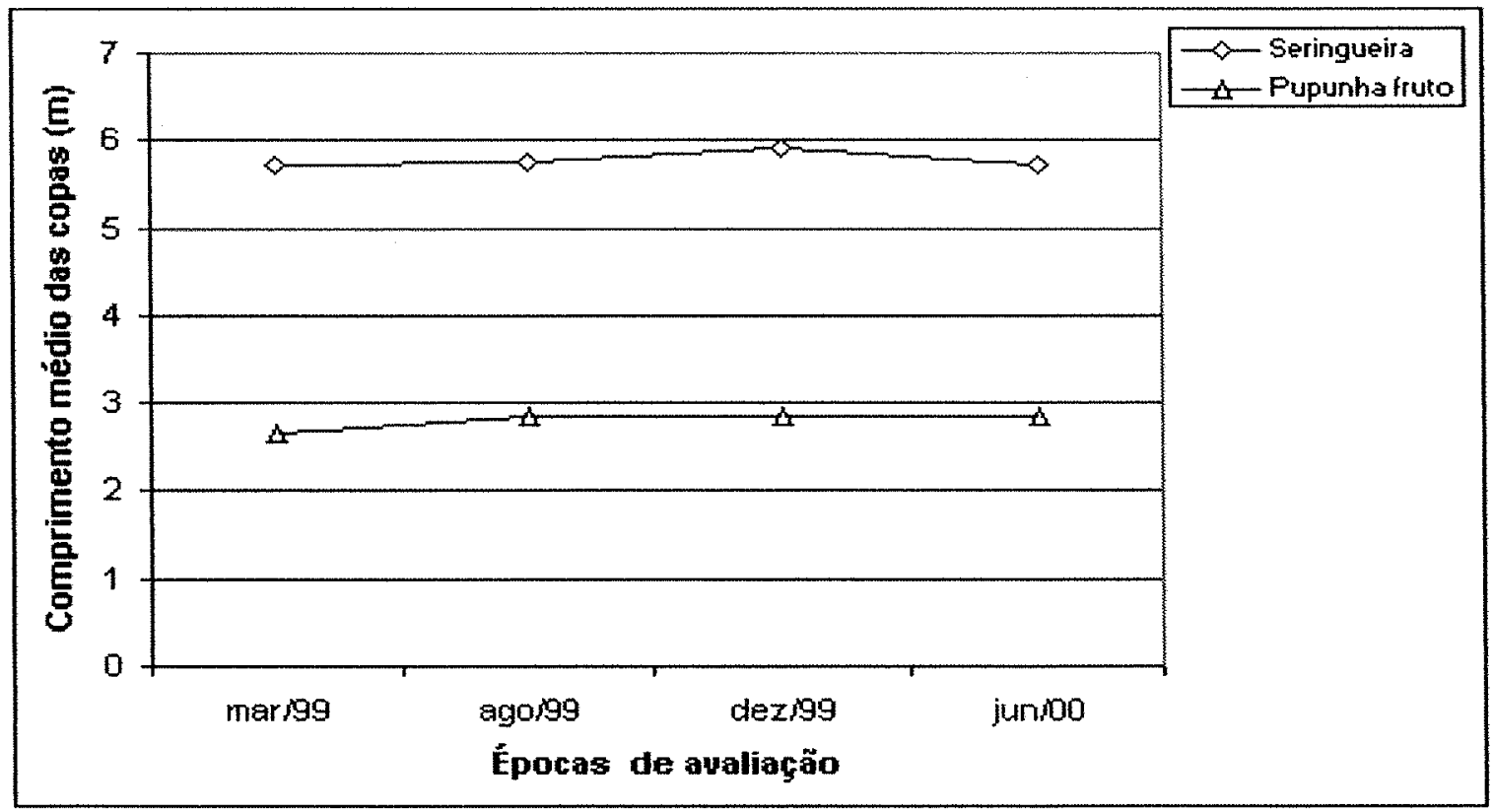

Figura 28 - Comprimento médio das copas $(\mathrm{m})$ de seringueira e de pupunheira para a produção de frutos no SAF 1. 


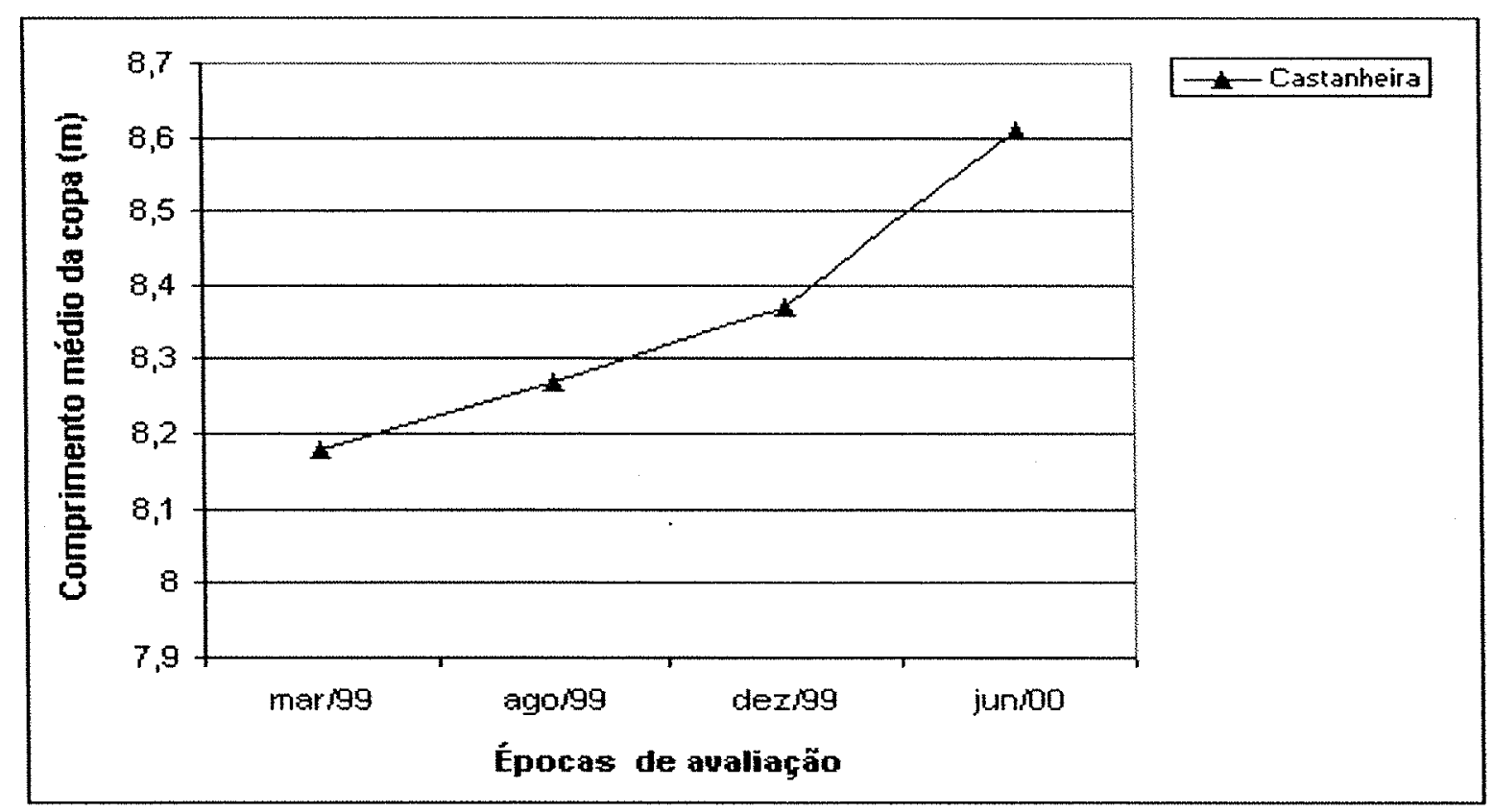

Figura 29 - Comprimento médio da copa $(\mathrm{m})$ de castanheira-do-brasil no SAF 2.

\subsection{Relações entre a produção e os fatores climáticos}

De uma maneira geral, o SAF 1 foi mais produtivo que o SAF 2. Isto se deve não apenas ao fato deste possuir um maior número de plantas de pupunha, mas também pelas espécies de árvores vizinhas que o compõem, ao maior espaçamento entre as pupunheiras e as árvores vizinhas, resultando em uma maior quantidade de radiação solar disponivel para as linhas de pupunheira.

A irradiância relativa corrigida ( $1 \%$ corrigido) apresentou resultados diferentes para cada época de avaliação (Tabela 16), devido ao crescimento das árvores vizinhas, disponibilizando quantidades diferentes de luz às pupunheiras. À medida que estas árvores cresciam, formando uma barreira maior, a quantidade de luz que atingia as pupunheiras era menor, portanto, o 
I $\%$ corrigido decrescia. O I\% corrigido do SAF 1 foi sempre maior que do SAF 2.

Tabela 16. Irradiância relativa corrigida ( $\mathrm{l} \%$ corrigido) entre os sistemas agroflorestais e entre as épocas de avaliação.

\begin{tabular}{lllll}
\hline Tratamentos & \multicolumn{4}{c}{ Épocas } \\
\cline { 2 - 5 } & mar/99 & ago/99 & dez/99 & jun/00 \\
\hline SAF 1 & 0,8819 & 0,8441 & 0,8085 & 0,7935 \\
SAF 2 & 0,7621 & 0,7423 & 0,7314 & 0,7063 \\
\hline
\end{tabular}

A relação entre produção e irradiância esta representada na Figura 30. Pode-se observar que a produção está intimamente relacionada com a quantidade de luz que chega até a cultura, comprovada pela regressão linear, estatisticamente significante ao nível de $95 \%$ de probabilidade $\left(r^{2}=0,6181\right)$, existente entre eles. A produção total de palmitos foi maior nas condições em que a irradiância também foi maior. Righi (2000), também encontrou alta correlação entre $1 \%$ e produção de fitomassa do feijoeiro em SAF com seringueiras.

Pode ser verificado neste estudo que a pupunheira apresentou diferenças quanto a sua produção dada a sua proximidade ou distanciamento das linhas das árvores vizinhas e as diferentes alturas destas árvores. No SAF 1, que foi o mais produtivo, as linhas de pupunheiras localizavam-se mais afastadas das linhas das árvores vizinhas, numa distância de $10 \mathrm{~m}$ das árvores mais altas do sistema, as pupunheiras para extração de frutos, permitindo uma maior irradiância. No SAF 2, a linha de pupunheiras apresentava-se entre as linhas de árvores mais altas do sistema, a castanheira-do-brasil, a uma distância apenas de $4 \mathrm{~m}$, o que permitiu uma menor irradiância. 
Bernardes et al. (1998b) observaram que a disponibilidade de radiação à cultura intercalar é o principal fator determinante do crescimento e da produção, quando os outros fatores não são limitantes. No presente estudo, a mesma relação foi observada entre disponibilidade de radiação e a produção, das pupunheiras. Para uma provável mesma condição hídrica no solo entre o SAF 1 e o SAF 2, aquele em que as pupunheiras receberam uma maior incidência de luz, a produção também foi maior. No entanto, não só a disponibilidade de luz foi responsável pelas variações de produção. O período de seca que antecedeu a terceira avaliação contribuiu para o aumento na emissão de perfilhos e folhas por planta, favorecendo então a produção da colheita posterior, como discutido no item 4.2.7.

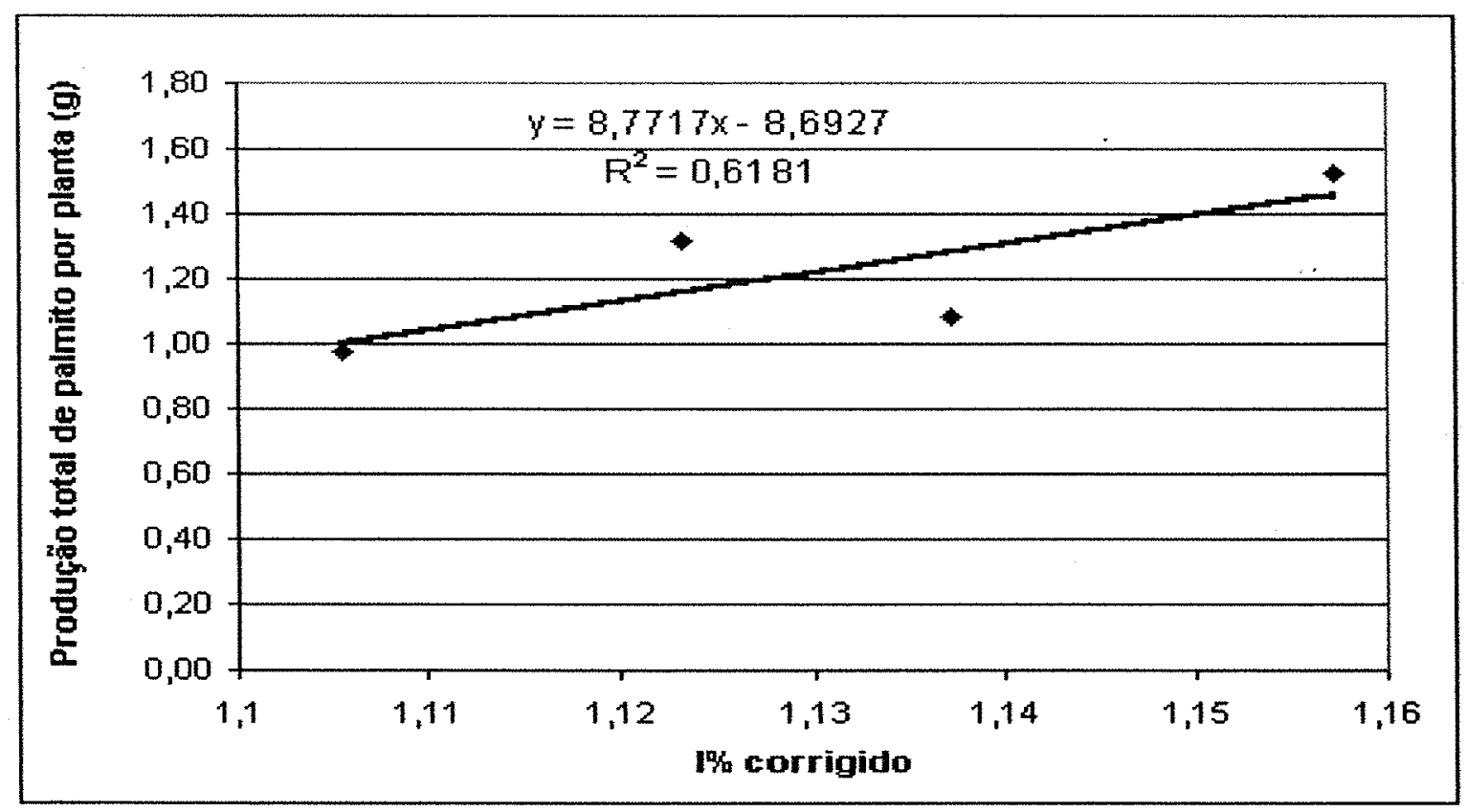

Figura 30 - Regressão linear entre $\mathrm{I} \%$ corrigido e produção de palmito por planta (g) no SAF 1 e no SAF 2. 
Deve-se considerar também que o intervalo de corte entre a segunda e a terceira época foi menor (quatro meses), enquanto que o intervalo entre a terceira e a quarta época foi maior (seis meses), proporcionando que um maior número de plantas alcançassem o ponto de colheita.

Teixeira (1997), comparando a umidade nas camadas superficiais do solo bem próximo a estas palmeiras com as camadas próximas às castanheiras, cupuaçuzeiros e urucuzeiros, detectou que próximo as pupunheiras ocorreram os menores valores de umidade no solo. Em estudos complementares, Haag (1997) constatou que a deficiência de água no solo apresentou conseqüências mais severas para as pupunheiras do que para as outras espécies que compunham os SAFs, devido ao seu sistema radicular concentrar-se na camada superficial do solo. Emmerich (1998), estudando a distribuição das raízes de pupunheira em SAFs, confirma estes resultados. Verificou que a biomassa das raízes finas das plantas de pupunheira, concentram-se nos primeiros $10 \mathrm{~cm}$ da camada de solo. Ferreira et al. (1980) observaram que $58,1 \%$ do total da massa radicular desta palmeira foram encontrados nos primeiros $20 \mathrm{~cm}$ da superfície do solo.

No entanto, embora os estudos demonstrem que a concentração de raízes da pupunheira esteja na camada superficial do solo, Haag (1997) e Bovi et al. (1999) verificaram que as raízes dessas palmeiras atingiram profundidades de 1,5 a $2,0 \mathrm{~m}$.

\section{5 Considerações finais}

Fatos que ocorreram em dezembro/99 foram conseqüências da baixa precipitação e alta intensidade luminosa ocorrida anteriormente a esta avaliação. Em junho/00, foram em virtude de um maior intervalo entre os dois últimos cortes para a colheita de palmito associado a retomada do crescimento meristemático das pupunheiras após um periodo de alta precipitação pluviométrica. 
Nos períodos de dezembro/99 e junho/00 observaram-se maior perfilhamento e maior emissão de folhas por planta de pupunheira com relação a março/99 e agosto/99. Em dezembro/99 notou-se uma redução da massa da matéria seca foliar e da massa seca dos estipes com relação a agosto/99 e junho/00. Na avaliação realizada em março/99 verificou-se que o IAF mostrouse mais elevado no monocultivo com relação aos SAFs. Em dezembro/99 o IAF revelou-se superior no monocultivo, enquanto que os sistemas apresentaram comportamento semelhante. Nos períodos de março/99 a junho/00, o diâmetro de copa e a altura das plantas mostraram-se semelhantes entre os dois SAFs.

Em dezembro/99 observou-se menor número de palmitos colhidos com relação a março/99, agosto/99 e junho/00 e o diâmetro e o comprimento do palmito foram semelhantes em todas as épocas de avaliação. Em dezembro/99 observou-se uma baixa produção de palmito creme e nos períodos de março/99 e junho/00 observou-se que a produção total de palmitos por planta foi maior com relação a agosto/99 e dezembro/99.

Para futuros experimentos com pupunheiras em SAFs, deve-se aumentar o número de épocas para as avaliações e o número de plantas avaliadas para se obter maiores detalhes de dados de irradiância e de produção.

O modelo matemático empregado no presente estudo para medir irradiância deve ser utilizado como ferramenta para o planejamento dos SAFs, na escolhas das espécies para compô-lo e na disposição das mesmas.

As variáveis analisadas apresentaram C.V. (coeficiente de variação) alto, e isto deve-se, provavelmente, a grande variabilidade existente na população de pupunheira.

A pupunheira é bastante exigente em água e o uso de cálculos e instrumentos que possam auxiliar a medição da quantidade de água no solo, a quantidade de água absorvida e transpirada pela planta, podem contribuir para o melhor entendimento e indicar o SAF mais viável economicamente para o produtor. 
Previamente a este estudo, os três SAFs receberam manejo bem diferenciados entre si e este fato pode ter contribuído para os diferentes resultados aqui obtidos.

A comparação do desempenho dos SAFs e do monocultivo, depende da produção das diversas espécies, que não foi avaliada no presente estudo. 


\section{CONCLUSÕES}

Pelos dados experimentais pode-se concluir que:

a) Há um efeito positivo da radiação solar disponivel sobre a produção de palmito de pupunheiras.

b) O perfilhamento e a emissão foliar são maiores nos períodos de aumento de brilho solar.

c) A pupunheira apresentou uma variação significativa de produção e crescimento entre as épocas de avaliação.

d) O modelo matemático proposto é um método eficiente para estimar a produção das pupunheiras sombreadas em SAFs. 


\section{REFERÊNCIAS BIBLIOGRÁFICAS}

ALMEYDA, N.; MARTIN, F.W. Cultivation of neglected tropical fruits with promise. Washington: USDA, 1980. cap. 8, p. 10-24: The pejibaye.

BANDY, D.; GARRITY, D.P.; SÁNCHEZ, P. El problema mundial de al agricultura de tala y queima. Agrofloresteria en las Américas, v.1, n.3, p.14-20, 1994.

BARBOSA, A.M.M. Pupunha (Bactris gasipaes) In: ENCONTRO SOBRE PRODUÇÃO DE PALMITO, Piracicaba, 1993. Anais. Piracicaba: CALQ, 1993. p 8-11.

BARTELINK, H. H. Simulation of radiation interception and transmission in forest stands: model documentation and examples. Wageningen: Department of Forestry, Agricultural University Wageningen, 1996. 35 p. (Hinkellord Report, 19)

BEER, J.; LUCAS, C.; KAPP, G. Reforestacion con sistemas agrosilviculturales permanentes versus plantaciones puras. Agroforesteria en las Américas, v. 1, n.3, p. 21-25, 1994. 
BERNARDES, M.S. Fotossíntese no dossel das plantas cultivadas. In: CASTRO, P.R.C.; FERREIRA, S.O.; YAMADA, T. (Ed.) Ecofisiologia da produção. Piracicaba: POTAFOS, 1987, cap.2, p.13-48.

BERNARDES, M.S. Efeito de métodos químicos de indução de copa no desenvolvimento da seringueira (Hevea brasiliensis Muell. Arg. cv. RRIM 600). Piracicaba, 1989. 192p. Dissertação (Mestrado) - Escola Superior de Agricultura "Luiz de Queiroz", Universidade de São Paulo.

BERNARDES, M.S.; LIMA, S.F.F. Curso de atualização em relações solo-planta-atmosfera: densidade populacional, disposição e direção de linhas de plantio, manejo da copa e a luz como fator essencial. Piracicaba: ESALQ, 2000. 55p.

BERNARDES, M.S. ; VICCARIO, L.R. Aspectos fitotécnicos do plantio e condução do seringal em desenvolvimento. In: SIMPÓSIO SOBRE A CULTURA DA SERINGUEIRA NO ESTADO DE SÃO PAULO, Piracicaba, 1986. Anais. Campinas: Fundação Cargill, 1986. p.193228.

BERNARDES, M.S.; CROMBERG, V.U.; FÚRIA, L.R.R.; MARTINS, A.N. Influence of nursery conditions on germination and initial development of pejibaye (Bactris gasipaes). Revista de Biologia Tropical, v.44, n.2, p. $499-505,1996$. 
BERNARDES, M.S.; GOUDRIAAN, J.; CÂMARA, G.M.S.; DOURADO NETO, D. Interações acima e abaixo da superfície do solo em sistema agroflorestal de seringueira (Hevea brasiliensis) e soja (Glycine max). In: CONGRESSO BRASILEIRO DE AGROMETEOROLOGIA, 10., Piracicaba, 1997. Anais. Piracicaba: Sociedade Brasileira de Agrometeorologia, 1997. p. 549-551.

BERNARDES, M.S.; GOUDRIAAN, J.; DOURADO NETO, D.; CÂMARA, G.M.S. Tree-crop interactions in agroforestry system of rubber with soybean and maize. In: CONGRESS FOR THE EUROPEAN SOCIETY OF AGRONOMY, 5., Nitra, 1998. Short communications. Nitra: ESA, 1998a. v.2, p. 125-126.

BERNARDES, M.S.; TERUEL, D.A.J.; SPAROVEK, G.; DOURADO NETO, D. Modelos ambientais e sustentabilidade. (compact disc) In: WORKSHOP DE AGRICULTURA SUŚTENTÁVEL EM REGIÕES TROPICAIS DE RELEVO ACIDENTADO, 3., Paty dos Alferes, 1998c. Anais. Rio de Janeiro: EMBRAPA, CNPS, 1998b. (EMBRAPA, CNPS. Boletim de Pesquisa, 9).

BERNARDES, M.S.; CHRISTOFFOLETI, P. J.; SAMPAIO, L. S.; COSTA, J. D.; LOUREIRO, R. F. A. Weeds in agroforestry system: a critical review. In: INTERNATIONAL WEED SCIENCE CONGRESS, 3., Foz do Iguassu, 2000. Proceedings. Foz do Iguassu: International Weed Science Society. No prelo. 
BERNARDES, M.S.; SPAROVEK, G.; ROSSETO, R.; FARHAT, M. VICCINO, J.R.; STAPE, J.L.; FILHO, V.A.C.; HAMMERSCHLAG, N. Sistemas de produção para áreas com restrições à colheita mecanizada de cana-de-açúcar. In: SEMANA DA CANA-DE-AÇÚCAR DE PIRACICABA, 3., Piracicaba, 1998. Anais. Piracicaba: STAB, 1998c. p. 35-37.

BOAS, O. Uma breve descrição dos Sistemas Agroflorestais na América Latina. IF. Série Registros São Paulo, n.8, p.1-16, 1991.

BOVI, M.L.A. Palmito pupunha: informações básicas para o cultivo. In: ENCONTRO SOBRE PRODUÇÃO DE PALMITO, Piracicaba,1995. Anais. Piracicaba: CALQ, 1995. p. 12-33.

BOVI, M.L.A. Palmito pupunha: informações básicas para cultivo. Campinas: Instituto Agronômico, 1998. 50 p. (IAC. Boletim Técnico, 173).

BOVI, M.L.A.; GODOY JÚNIOR, G.; SAES, L.A. Pesquisas com os gêneros Euterpe e Bactris no Instituto Agronômico de Campinas. In: ENCONTRO NACIONAL DE PESQUISADORES EM PALMITO. Curitiba, 1988. Anais. Colombo: Embrapa, CNPF, 1988. p. 1-43.

BOVI, M. L. A.; SAES, L.A.; GOGOY JÚNIOR, G. Correlações fenotípicas entre caracteres não destrutiveis e palmito em pupunheiras. Turrialba, v. 42, n. 3, p. 382-390, 1992.

BOVI, M.L.A.; SPIERING, S.H.; BARBOSA, A.M.M. Densidade radicular de progênies de pupunheira em função de adubação NPK. Horticultura Brasileira, v.17, n.3, p. 186-193, 1999. 
BREWBAKER, J.L. Significant nitrogen fixing trees in agroforestry systems. In: H.L. GHOLZ (Ed.). Agroforestry: realities, possibilities and potentials. Dordrecht, The Netherlands: Martius Nijhoff, 1987. p. 31- 46 .

BROONKIRD, S.A.; FERNANDES, E.C.M.; NAIR, P.K.R. Forest villages: an agrofloresty approach to rehabilitating forest land degraded by shifiting cultivation in Thailand. Agroforestry Systems, v.2, p.87-102, 1984.

CAMACHO, V.E. El pejybayo (Guilielma gasipaes (H.K.B.) Bailey). In: SIMPÓSIO INTERNACIONAL SOBRE PLANTAS DE INTERESSE ECONÔMICO DE LA FLORA AMAZONICA, Belém, 1972. Turrialba: IICA, 1976. p. 101-106.

CANTO, A. do C.; SILVA, S.E.L da; NEVES, E.J.M. Sistemas agroflorestais na Amazônia Ocidental: aspectos técnicos e econômicos. In: ENCONTRO BRASILEIRO DE ECONOMIA E PLANEJAMENTO AGROFLORESTAL, Manaus, 1992. Anais. Manaus: Embrapa, 1992. p.23-36.

CASTRO, D. S.; BERNARDES, M.S. Estudos das relações de luz em sistemas agroflorestais de seringueira. Piracicaba: FAPESP, 1998, 45 p. (Relatório de Estudos).

CASTRO, P. R. C.; BERNARDES, M. S. Ecofisiologia de cultivos tropicais: a luz como fator essencial e a sua modelagem como forma de entendimento (compact disc). In: CONGRESSO BRASILEIRO DE FISIOLOGIA VEGETAL, 7., Ilhéus, 2001. Fisiologia de plantas no novo milênio: desafios e perspectivas; anais. Ilhéus: CEPLAC, 2001. 
CHAZDON, R.L.; FETCHER, N. Photosynthetic light environments in a lowland tropical rain forest un Costa Rica. Journal of Ecology, v.72, 553-564, 1984.

CHONG, D. T;; TAJUDDIN, I.; Abd. SAMAT, M.S. Productivity of cover crops and natural vegetation under rubber in Malaysia. In: SHELTON, H.M.; STUR, W. W. (Ed.) Forage for plantation crops. Samur Beach: ACIAR, 1991. p.36-37.

CLEMENT, C.R. Pupunha: uma árvore domesticada. Ciência Hoje, v.5, n.29, p. 42-49, 1987.

CLEMENT, C.R. Domestication of the pejibaye palm (Bactris gasipaes): past and present. Ecology Botanic, v.6, p. 155-174, 1988.

CLEMENT, C.R. Growth and analysis of pejibaye (Bactris gasipaes Kunt, Palmae) in Hawaii. Honolulu, 1995. 221p. Thesis (Ph.D.) - University of Hawaii.

CLEMENT, C.R.; CHÁVEZ FLORES, W.B.; MOREIRA GOMES, J.B. Considerações sobre a pupunha (Bactris gasipaes H.B.K.) como produtora de palmito. In: ENCONTRO NACIONAL DE PESQUISADORES EM PALMITO, Curitiba, 1988. Anais. Colombo: Embrapa, CNPF, 1988. p. 225-247.

CLEMENT, C.R. \& BOVI, M.L.A. Padronização de medidas de crescimento e produção em experimentos com pupunha para palmito. Acta Amazônica, v. 30, n. 3, p. 349-362, 2000. 
DENICH, M.; KANASHIRO, M. Possibilidades de utilização e manejo adequado de áreas alteradas e abandonadas na Amazônia brasileira. Brasilia: MCT; CNPq, 1998. 157 p. (Estudos dos Impactos Humanos nas Florestas e Áreas Inundadas nos Trópicos - SHIFT.)

EMMERICH, S. Distribution of roots of tropical useful plants in an agroforestry system four years after installation. In: GASPAROTTO, L.; SCHROTH, G. Relatório anual. Manaus: Embrapa, CPAA, 1998. p.14-19. (Projeto SHIFT Embrapa, CPAA; Universidade de Hamburgo).

EMPRESA BRASILEIRA DE PESQUISA AGROPECUÁRIA. Centro de Pesquisa Agroflorestal da Amazônia Ocidental. Programa nacional de pesquisa agroflorestal. Manaus: CPAA, 1991. 39p.

EMPRESA BRASILEIRA DE PESQUISA AGROPECUÁRIA. Boletim agrometeorológico. Manaus: Embrapa, CPAA, 1997. 19p.

ENGEL, V.L. Introdução aos sistemas agroflorestais. Botucatu: FEPAF, 1999. 70p.

FERREIRA, S.A.N.; CLEMENT, C.R.; RANZANI, G. Contribuição para o conhecimento do sistema radicular da pupunheira (Bactris gasipaes H.B.K. - Guilielma gasipaes (H.B.K.) Bailey) I - Solo Latossolo Amarelo textura média. Acta Amazônica, v.10, n.2, p. 245-249, 1980.

FERREIRA, V.L.P. Caracterização físico-químico-bioquímica e organoléptica do palmito proveniente da palmeira Guilielma gasipaes Bayle (pupunha) em relação ao palmito da palmeira Euterpe edulis Mart (juçara). Piracicaba, 1982. 73p. Dissertação (Mestrado) - Escola Superior de Agricultura "Luiz de Queiroz", Universidade de São Paulo. 
FNP CONSULTORIA \& COMÉRCIO. Agrianual 99: anuário da agricultura brasileira. São Paulo, 1999. p.415-421: Palmito.

GARNER, W.W.; ALLARD, H.A. Effects of the relative length of day and night and other factors the environment on growth and reproduction in plants. Journal of Agricultural Research, v.18, n. 11, p.553-609, 1920.

GASPAROTTO, L.; MACÊDO, J.L.V.; LIEBEREI, R.; MORAES, C.R.A. et al. Aproveitamento de áreas abandonadas na Amazônia Ocidental através de sistemas agrossilviculturais. Pesquisa em Andamento. n. 32, p. 1-6, 1998.

GERNEK, E.B.; ARRUDA, H.V.; SANTOS, R.R.; CIONE, J.; SCARANARI, H.J.; MARTINS, F.F. Comportamento da palmeira pupunha (Guilielma gasipaes L.H.Bailey) em três localidades do estado de São Paulo. In: CONGRESSO BRASILEIRO DE FRUTICULTURA, 6., Recife, 1981. Anais. Recife: Sociedade Brasileira de Fruticultura, 1981. p.1198-1206.

GIJZEN, H.; GOUDRIAAN, J. A flexible and explanatory model of light distribuition and photosysthesis in row crops. Agricultural and Forest Meteorology, v. 48, p.1-20, 1989.

GOLLEY, F.B. Ecodevelopment. In: POGIANNI, F.B. (Ed.) Tropical rain forest ecosystems: structure and function. Amsterdam: Elsevier Scientific, 1983. cap. 10, p.335-345. 
GOMES, A.R.S. Sistemas agrossilviculturais do sudeste da Bahia. In: ENCONTRO BRASILEIRO DE ECONOMIA E PLANEJAMENTO FLORESTAL, 2., Curitiba, 1992. Anais. Curitiba: Embrapa, CNPF, 1992. p. 109-122.

GOMES, J.B.M.; ARKCOLL, D.B. Estudos iniciais sobre a produção de palmito de pupunha. In: ENCONTRO NACIONAL DE PESQUISADORES EM PALMITO, Curitiba, 1988. Anais. Colombo: Embrapa, CNPF, 1988. p. 271-278.

GOMES, J.B.M.; MENEZES, J.M.T.; VIANA FILHO, P. Efeito de niveis de adubação e espaçamento na produção de palmito de pupunheira em solo de baixa fertilidade na região de Ouro Preto d'Oeste - RO. In: ENCONTRO NACIONAL DE PESQUISADORES EM PALMITO, Curitiba, 1988. Anais. Colombo: Embrapa, CNPF, 1988. p. 261-266.

GOUDRIAN, J. Crop micrometeorology: a simulation study. Wargening: Pudoc, 1977. 249 p. (Simulation Monographs).

HAAG, D. Root distribution patters in a polycultural system with local tree crops on an acid upland soil in central Amazonia. Bayreuth, 1997. 85p. Thesis (Diplom.) - Universidade de Bayreuth.

KNEVEL, M. Solitary trees: light interception and shade patterns. Wageningen: Department of Theoretical Production Ecology, Agricultural University Wageningen, 1993. 92 p. 
LUNZ, A. M.P.; FRANKE, I.L.; SÁ, C.P.; ANDRADE, C.M.S. Caracterização e avaliação de sistemas agroflorestais na Amazônia Ocidental: Projeto RECA, um estudo de caso. In: CONGRESSO BRASILEIRO DE SISTEMAS AGROFLORESTAIS, 3., Manaus, 2000. Anais. Manaus: Embrapa, CPAA, 2000. p. 349-352.

MACEDO, R.L.G. Sistemas agroflorestais com leguminosas arbóreas para recuperar áreas degradadas por atividades agropecuárias. In: SIMPÓSIO NACIONAL SOBRE RECUPERAÇÃO DE ÁREAS DEGRADADAS, Curitiba, 1992. Anais. Curitiba: UFPR, FUPEP, 1992. p.136-147.

MACEDO, R.L.G.; CAMARGO, I.P. Sistemas agroflorestais no contexto do desenvolvimento sustentável. In: CONGRESSO BRASILEIRO SOBRE SISTEMAS AGROFLORESTAIS, Porto Velho, 1994. Anais. Colombo: EMBRAPA, CNPF, v.2, 1994. p. 43-49. (Documentos, 27).

MACEDO, R.L.G.; TSUKAMOTO FILHO, A.A.; VENTURINI, N.; RONDON NETO, R.M. Sistemas agroflorestais: principios, caracterização e classificação. Lavras: UFLA, 1999. 35p. (Boletim Agropecuário).

MACEDO, J.L.V. de; MORAES, C.R.A.; MOTA, A.M. Production of peach palm (Bactris gasipaes) for palm heart in differet polyculture systems. In: GASPAROTTO, L.; SCHROTH, G. Relatório anual. Manaus: Embrapa; CPAA, 1998. p. 46-50. (Projeto SHIFT. Embrapa, CPAA; Universidade de Hamburgo). 
MONSI, M.; SAEKI, T. Uber den lichtfacktor in den pflanzen-gesellschaften und seine bedeutung fur die Stoffproduktion. Japanese Journal of Botany., v.14, p.22-52, 1953.

MONTAGNINE, F. Sistemas agroflorestais: princípios y aplicaciones em los trópicos. 2.ed. San José: Organización para Estudios Tropicales, 1992. 622p.

MONTEITH, J.L.; ONG, C.K.; CORLETT, J.E. Microclimatic interactions in agroforestry systems. Forest Ecology and Management, v. 45, p.3144, 1991.

MORA URPI, J. El pejibaye (Bactris gasipaes HBK): origen, biologia floral y manejo agronómico. In: PALMERAS POCO UTILIZADAS DE AMÉRICA TROPICAL, Turrialba, 1984. Anais. Turrialba: FAO; CATIE, 1984. p.118-160.

PEREIRA, A. R. Competição intra-específica entre plantas cultivadas. 0 Agronômico, v.41, p.5-11, 1989.

PUKKALA,T.; KUULUVAINE, T. Effect of canopy structure on the diurnal interception of direct solar radiation and photosyntheis in a tree stand. Silva Fennica, v. 21, p.237-250, 1987.

RAMOS, A. Desenvolvimento vegetativo da pupunheira (Bactris gasipaes Kunth) irrigada por gotejamento em função de diferentes níveis de depleção de água no solo. Piracicaba, 1998. 66p. Dissertação (Mestrado) - Escola Superior de Agricultura "Luiz de Queiroz", Universidade de São Paulo. 
REICHARDT, K. Dinâmica da matéria e da energia em ecossistemas. Piracicaba: ESALQ, 1993. 505p.

RIGHI, C.A. Interações ecofisiológicas acima e abaixo do solo em um sistema agroflorestal de seringueira (Hevea brasiliensis) e feijoeiro (Phaseolus vulgaris). Piracicaba, 2000. 121p. Dissertação (Mestrado)Escola Superior de Agricultura "Luiz de Queiroz", Universidade de São Paulo.

RIGHI, C.A.; BERNARDES, M.S. Modificações morfológicas e fenológicas em feijão (Phaseolus vulgaris L.) provocadas por sombreamento em sistema agroflorestal com seringueiras (Hevea brasiliensis Muell). In: REUNIÄO NACIONAL DE PESQUISA DE FEIJÃO, Salvador, 1999. Resumo expandido. Santo Antônio de Goiás: EMBRAPA, CPAF, 1999. p. 94-97.

ROTHSCHUH, J. Guia técnico para o cultivo del pejibaye (Bactris gasipaes H. B. K.). Turrialba: Ministério de Desarollo Agropecuário y Reforma Agrária; IICA. Fondo Simon Bolívar, 1983. 24p. (IICA - Série de publicaciones miscelâneas, 445)

RUTHEMBERG, H. Farming systems in the tropics. Oxford: Claredon Press, 1980. 202p.

SCHROTH, G.; ELIAS, M.E.A.; MACÊDO, J.L.V.; MOTA, M.S.S.; LIEBEREI, R. Mineral nutrition of peach palm (Bactris gasipaes) in Amazonian agroforestry and recommendations for foliar analisys. European Journal of Agronomy, 2001. No prelo. 
SHEPPERD, W.D. An instrument for measuring tree crown width. Fort Collins: USDA, Forest Service, 1973. 3p. (USDA. Forest Service Research Note, RM-229).

SILVA, I.C.; DIAS, A.C. da C.P. Intercultivo da pupunheira com cacaueiro na Amazônia brasileira, resultados parciais. Revista Theobroma, n.17, v.2, p.93-100, 1987.

SILVA, F.M.S.; YUYAMA, K. Desenvolvimento da pupunheira (Bactris gasipaes Kunth) para produção de palmito, em sistemas de monocultivo e consorciação com outras culturas de ciclo curto. In: CONGRESSO BRASILEIRO DE OLERICULTURA, 37., 1997, Manaus. Resumos. Brasília: SOB, 1997. p. 85-86.

SILVA, S.E.L. da. Produção de mudas de pupunheira (Bactris gasipaes H.B.K.) . Comunicado Técnico, EMBRAPA, CPAA, n.11, p.1-6, 1998.

TEIXEIRA, W.G.; FACCIN, O.P.; HUWE, B.; SCHROTH, G. Utilização da técnica de reflectometria do tempo (TDR) para o monitoramento da umidade do solo em um sistema agroflorestal na Amazônia. In: WORKSHOP ON SPECIAL ABOUT SOIL PHISICS AND CROP MODELING AND SIMULATION, Piracicaba, 1997. Anais. Jaguariúna: Embrapa; CNPMA, 1997. p.71-77.

TOMLINSON, P.B.; JEFFREY, E.C. The structural biology of palms. Oxford: Claredon Press, 1990. cap. 5, p. 99-120: Mature vegetative phase.

TORQUEBIAU, E. F. A renewed perspective on agroforestry concepts and classification. Life Sciences, n. 323, p. 1009-1017, 2000. 
VILLACHICA L., H. Cultivo del pijuayo (Bactris gasipaes Kunth) para palmito en la Amazonia. Lima: PNUD, 1996a. 153 p.

VILLACHICA, L.H. Pijuayo. In: CARVALHO, J.E.U.; MÜLLER, C.H.; DIAZ, C.S.; ALMANZA,M. (Ed.) Frutales y hortalizas promisorios de la Amazonia. Lima: PNUD, 1996b. p.216-224.

WANDELLI, E.V.; MARQUES FILHO, A.O. Medidas de radiação solar e índice de área foliar em coberturas vegetais. Acta Amazônica, v. 29, n.1, p.57-78, 1999.

WORLD CONSERVATION STRATEGY. Living resource conservation for sustainable development. Washington: IUCN; UNEP; WWF, 1980, $36 \mathrm{p}$.

YUYAMA, K. Sistemas de cultivo para produção de palmito da pupunheira. Horticultura Brasileira, v. 15, p. 191-198, 1997. Suplemento. 